\title{
REGIONAL STRATIGRAPHY, ELEMENTAL CHEMOSTRATIGRAPHY, AND ORGANIC RICHNESS OF THE NIOBRARA MEMBER OF THE MANCOS SHALE, PICEANCE BASIN, COLORADO
}

\author{
by
}

\author{
AYA EL ATTAR \\ B.S., American University of Beirut, 2011
}

\author{
A thesis submitted to the \\ Faculty of the Graduate School of the \\ University of Colorado in partial fulfillment \\ of the requirement for the degree of \\ Master of Science \\ Department of Geological Sciences
}

2013 
This thesis entitled:

Regional Stratigraphy, Elemental Chemostratigraphy, and Organic Richness of the Niobrara Member of the Mancos Shale, Piceance Basin, Colorado

written by Aya El Attar

has been approved for the Department of Geological Sciences

Matthew J. Pranter

Rex D. Cole

David A. Sawyer

Date

The final copy of this thesis has been examined by the signatories and we Find that both the content and the form meet acceptable presentation standards Of scholarly work in the above mentioned discipline. 


\begin{abstract}
Aya El Attar (M.S., Geology [Department of Geological Sciences])

Regional Stratigraphy, Elemental Chemostratigraphy, and Organic Richness of the Niobrara Member of the Mancos Shale, Piceance Basin, Colorado
\end{abstract}

Thesis directed by Professor Matthew J. Pranter

The elemental chemostratigraphy of the Upper Cretaceous Niobrara Member of the Mancos Shale shows that six chemostratigraphic zones can be identified in the Piceance Basin, Colorado, based on geochemical data collected from cuttings at 10- , 20-, and 30-ft (3.05, 6.10, and $9.14 \mathrm{~m}$ ) intervals. Chemostratigraphic correlations of nine wells spaced $20 \mathrm{mi}$ ( $\sim 32 \mathrm{~km})$ apart closely match lithostratigraphic correlations made using gamma-ray and deep-resistivity logs. Lithologic interpretations made from wireline logs indicate that the Niobrara Member and equivalent strata consist primarily of interbedded calcareous shale and shaley limestone facies that increase in thickness to the northwest of the basin. The geochemical data suggest that during deposition of the Niobrara Member, anoxia and calcium enrichment increased to the east of the basin, whereas terrestrial input and clay enrichment increased to the northwest. Element cross-plots suggest that a large portion of the silicon is detrital and that the Niobrara Member becomes an increasingly more clastic than carbonate system to the west.

The $\Delta$ Log R-derived total organic carbon (TOC) calculated using a sonic-resistivity overlay analysis technique shows that the Niobrara Member comprises organic-rich and organicpoor deposits. Average TOC values range between 1 (in organic-poor deposits) and 2.37 wt.\% 
(in organic-rich deposits) with higher TOC values recorded in the southern and eastern portions of the basin. Relative-rock brittleness estimates from element and TOC data show the stratigraphic variability of alternating ductile (TOC rich, $\mathrm{Ca}$ and Si/Al poor) and brittle intervals (TOC poor, Ca and Si/Al rich) for the Niobrara Member. 


\section{DEDICATION}

I would like to dedicate this thesis to my parents, Najwa and Ghassan, and to my sisters, Sana and Nour.

À Mr. S. Zarifé. 


\section{ACKNOWLEDGMENTS}

I would like to express my appreciation to Matt Pranter for his limitless guidance, supervision, and advice throughout this work. I would like to thank Rex Cole and David Sawyer for reviewing and editing this thesis, and David Sawyer and Gus Gustason for long discussions

on the Niobrara stratigraphy. I would also like to thank Marc Connolly for all his knowledge and assistance in the petrophysical work. I would like to thank Mohammed Al-Qattan, Connor Burt, and Farah Abdelmawla for assisting with the XRF data collection, and Nate Rogers and Jon Cantwell for valuable discussions.

My friends at CU have made my stay in Boulder exceptional. Thank you Leighanna Hinojosa, Daniel Allen, John McFadden, Ryan Sharma, Ellen Wilcox, Gabriela Keeton, Chris Rybowiak, Chelsea Fenn, Tristan Betzner, and Mohammed Al-Qattan.

Tuba Evsan, you are an inspiration.

My two-year graduate studies were fully sponsored by the ExxonMobil Middle East \& North Africa program. I would like to thank them for all their support. This research was funded by the Reservoir Characterization and Modeling Laboratory (RCML) at CU-Boulder and sponsors of the Williams Fork Consortium (Phase VI): Anadarko Petroleum Corporation, Chevron Corporation, ExxonMobil Corporation, iRerservoir, Jason, Occidental Petroleum Corporation (Oxy), QEP Resources, Schlumberger, Suncor Energy, and WPX Energy. Additional support was provided by the AAPG Grants-in-Aid Foundation. IHS provided the subsurface interpretation software and Jason provided the well-log petrophysical analysis software. 


\section{CONTENTS}

PAGE

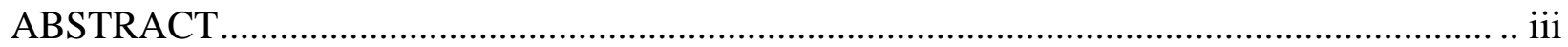

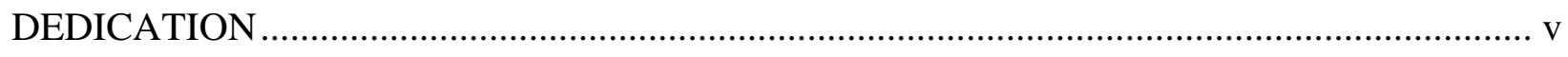

ACKNOWLEDGEMENTS ........................................................................................ vi

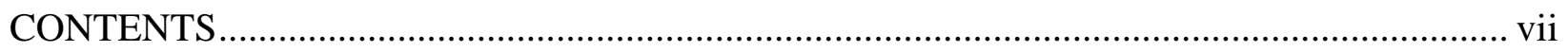

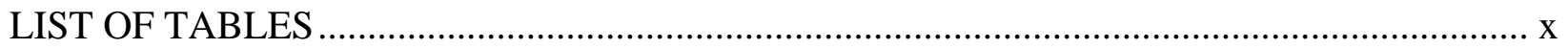

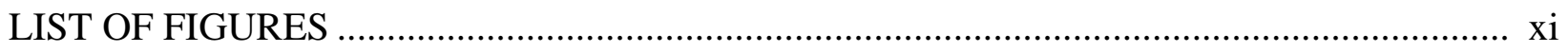

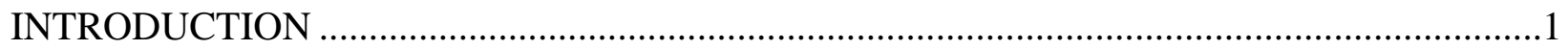

TECTONIC AND STRATIGRAPHIC SETTING ...........................................................6

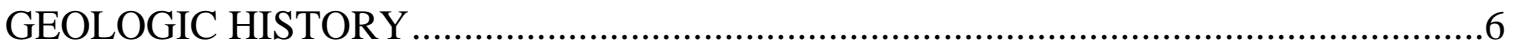

REVIEW OF NIOBRARA STRATIGRAPHY AND LITHOLOGY ..............................9

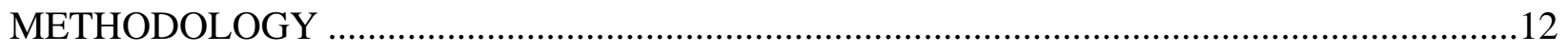

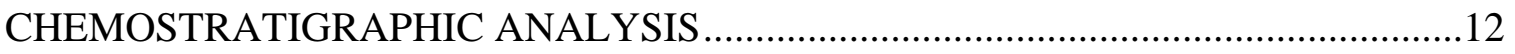

TOTAL ORGANIC CARBON AND $\triangle$ LOG R TECHNIQUE.....................................12

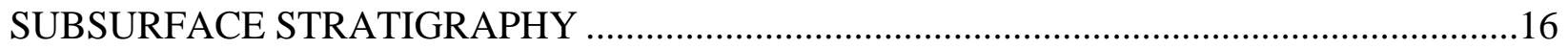

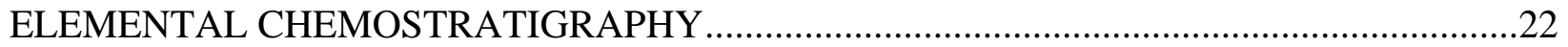

CHEMOSTRATIGRAPHIC ZONATION ................................................................22

CHEMOSTRATIGRAPHIC CORRELATIONS ......................................................26

LATERAL VARIATION OF ELEMENTS ........................................................27

CONTROLS ON ELEMENT DISTRIBUTION AND ABUNDANCE .........................32

INTERPRETATION OF CHANGES IN PALEOREDOX CONDITIONS .....................34

INTERPRETATION OF CHANGES IN TERRESTRIAL INPUT ................................36

STRATIGRAPHIC AND GEOGRAPHIC DISTRIBUTION OF ORGANIC MATTER............38

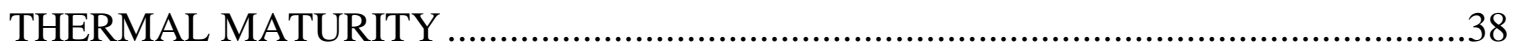




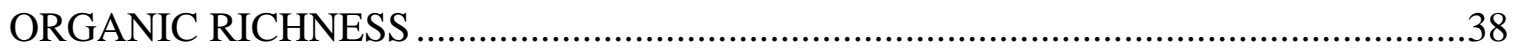

CALIBRATION AND ACCURACY OF TOC CALCULATIONS.................................42

QUALITATIVE INTERPRETATION OF RELATIVE ROCK BRITTLENESS ............45

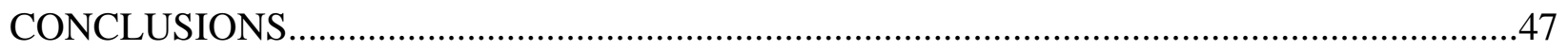

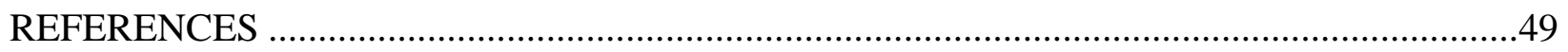




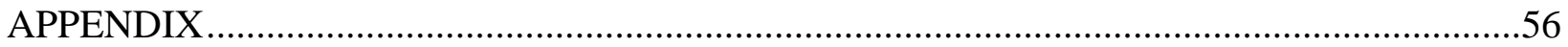

A. X-Ray Fluorescence (XRF) Data Collection ................................................................56

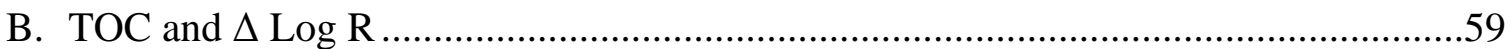

C. Lithostratigraphic Units ..............................................................................................

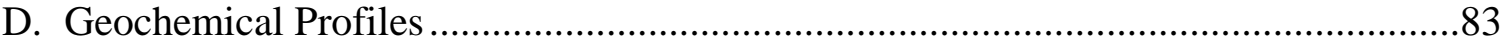

E. Element and Element Ratio Maps............................................................................92

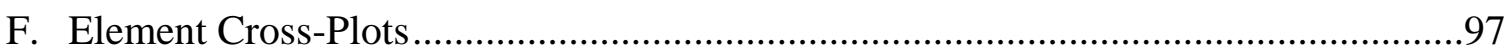

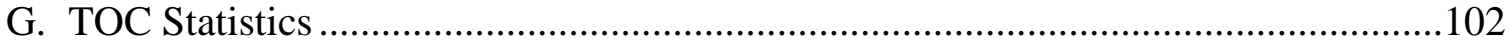




\section{LIST OF TABLES}

1: Well names and locations for XRF analyzed cuttings .......................................................

2: $\Delta$ Log R-derived TOC statistical summary (by chemostratigraphic zone).............................43

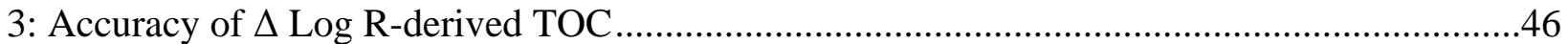




\section{LIST OF FIGURES}

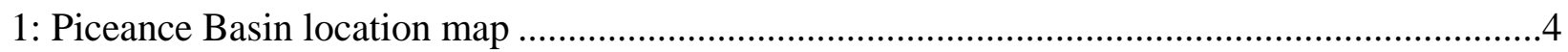

2: Cross section of Cretaceous strata in eastern Utah and western Colorado ...................................7

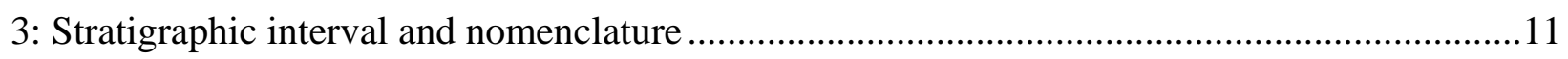

4: Schematic guide for interpreting $\Delta$ Log R motifs..................................................................14

5: $\Delta$ Log R technique example application - South Baxter Pass Unit well...................................17

6: Type Log for the Niobrara Member in the Piceance Basin .........................................................18

7: a- West-southeast regional cross section using gamma-ray and deep-resistivity logs ...............20

b- West-northeast regional cross section using gamma-ray and deep-resistivity logs ...............21

8: Key geochemical profiles for chemostratigraphic reference well .............................................24

9: Average Calcium maps (by chemostratigraphic zone) …………………………….................28

10: Average Molybdenum maps (by chemostratigraphic zone) ......................................................29

11: Average Aluminum maps (by chemostratigraphic zone) ……..................................................30

12: Average Silicon/Aluminum maps (by chemostratigraphic zone)..............................................31

13: Aluminum vs. Silicon cross-plots (by well) ………………………....................................3

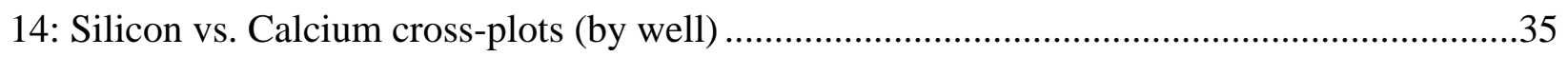

15: Level of Organic Metamorphism (LOM) map ……………………......................................39

16: a- West-southeast $\Delta$ Log R-derived TOC cross section .........................................................40

b- West-northeast $\Delta$ Log R-derived TOC cross section ............................................................41

17: Average $\Delta$ Log R-derived TOC maps (by chemostratigraphic zone).......................................44 


\section{INTRODUCTION}

The Upper Cretaceous Niobrara Formation and its stratigraphic equivalents produce both oil and gas in the Rocky Mountain region. Hydrocarbon production from chalks, marls, and marine shales of the Niobrara Formation and correlative parts of the Mancos Shale occurs in the Powder River, Denver, North Park, Sand Wash, San Juan, and Piceance basins. In 2009, the success of the horizontally drilled EOG Jake \#2-01H discovery well marked the beginning of an on-going exploitation of these low-permeability oil reservoirs in the Denver Basin in northeastern Colorado (Durham, 2012). In 2013, WPX Energy's Williams \# GM 801-4 HN1 discovery well (API\#: 05-045-21487; 04 07S 96W) produced at an initial rate of 16 million $\mathrm{ft}^{3}$ $\left(4.53 \times 10^{-7} \mathrm{~km}^{3}\right)$ of gas per day choked back (Durham, 2013), suggesting that the Niobrara Member gas play has the potential to be substantially prolific and economically viable in the Piceance Basin in northwestern Colorado. Unconventional shale gas resource plays are selfsourced systems, having generally low matrix permeability and continuous-type accumulations of biogenic and/or thermogenic gas.

The interval encompassed by the Niobrara Formation and equivalent rocks in Colorado is studied by several authors (e.g., Clayton and Swetland, 1980; Rice, 1984a, b; Barlow, 1985; Pollastro and Martinez, 1985; Precht and Pollastro, 1985; Molenaar and Wilson, 1990; Nuccio, 1990). However, published accounts detailing the hydrocarbon source-rock potential of the Niobrara Member and equivalent parts of the Mancos Shale are sparse, especially in northwestern Colorado (e.g., Vincelette and Foster, 1992; Longman et al., 1998; Landon et al., 2001; Fisher, 2007; Kuzniak, 2009; Rogers, 2012). Longman et al. (1998) showed that the organic-rich marine shales provide the main hydrocarbon source rocks of the Niobrara Member, and Vincelette and Foster (1992) tied major hydrocarbon production from the Niobrara Member 
in northwestern Colorado to the presence of post-Laramide fractures in the calcareous shales and marls. A comprehensive understanding of the stratigraphic and geographic relationships, as well as the origin and distribution of lithologies of source and reservoir rocks within the Niobrara, is essential in providing a framework for predicting the occurrence and distribution of hydrocarbon accumulations.

Seismic and petrophysical data are commonly used to develop lithostratigraphic and seismic stratigraphic frameworks. These data allow interwell correlations to be made; however, they sometimes lack the necessary resolution for detailed stratigraphic analysis (Pearce et al., 2005). The fine-grained, organic-rich, and seemingly homogenous nature of shale sequences has stimulated the search for new techniques that allow an improved understanding of reservoir stratigraphy. Consequently, chemical data and chemical stratigraphy (or chemostratigraphy) have become useful as an aid for stratigraphic correlation. Chemostratigraphic zonation relies upon the characterization of a sedimentary interval in terms of its major- and trace-element concentrations, whereas chemostratigraphic correlations refer to the extension of this characterization from one wellbore section to another (Ratcliffe et al., 2007; Pearce et al., 2008). To date, several authors have tested and reported the applicability of this technique in frontier and mature basins across the world (e.g., Ehrenberg and Siring, 1992; Racey et al., 1995; Pearce et al., 1999, 2005; Ratcliffe et al., 2004, 2007; Wright et al., 2010a, b). For example, Pearce et al. (2008) showed how a blind test of chemostratigraphic correlations compared well with lithofacies correlations made from outcrop measured sections of the Green River Formation, whereas Wright et al. (2010b) used chemostratigraphy as a means to infer bulk mineralogy and to model organic content using the Haynseville and Eagle Ford Formations shale gas plays as case studies. 
In this study, an approach to chemostratigraphy is used for stratigraphic correlation of the Niobrara Member interval in the Piceance Basin. A subsurface lithostratigraphic framework was established using gamma-ray (GR) and deep-induction resistivity (ILD) logs from 251 wells. After identifying key surfaces and correlating mappable intervals within the Niobrara Member, subdivisions were compared to previous work on the Lower Mancos Shale on the Douglas Creek Arch (Fisher, 2007; Kuzniak, 2009), and in the Piceance Basin (Rogers, 2012), as well as to the study by Vincelette and Foster (1992) in northwestern Colorado. Elemental data were acquired from a total of 960 drill-cutting samples (total footage of 15,430 ft [4,703.1 m]) from 9 wells across the basin using the Thermo Scientific Niton ${ }^{\circledR}$ XL3t 950 X-ray fluorescence (XRF) portable hand-held analyzer (Figure 1; Table 1). Average well spacing is approximately $20 \mathrm{mi}$ $(32.2 \mathrm{~km})$ and vertical sample spacing is 10,20 , or $30 \mathrm{ft}(3.05,6.10$, or $9.14 \mathrm{~m})$ (Appendix A, Table A-1). The geochemical data allowed the subdivision of the Niobrara Member into chemostratigraphic zones based on changes in elemental composition. Interwell correlations were made, and by generating element maps for each unit, stratigraphic and lateral changes of key elements were investigated.

In addition to the Niobrara Member chemostratigraphy, this study uses a petrophysical approach to evaluate the stratigraphic variation and lateral distribution of organic-rich intervals within the Niobrara Member. Total organic carbon (TOC) describes the organic matter concentration (in weight percent of organic carbon) in sedimentary rocks and is used to assess the quality of hydrocarbon source rocks. The $\Delta$ Log R technique (Passey et al., 1990), a porosity/resistivity overlay analysis, was applied in this study in order to identify organic-rich intervals and calculate TOC in 68 wells. The technique yields profiles of TOC at the combined resolution of the logging tools of approximately $3 \mathrm{ft}(1 \mathrm{~m})$ (Passey et al., 1990). Profiles 


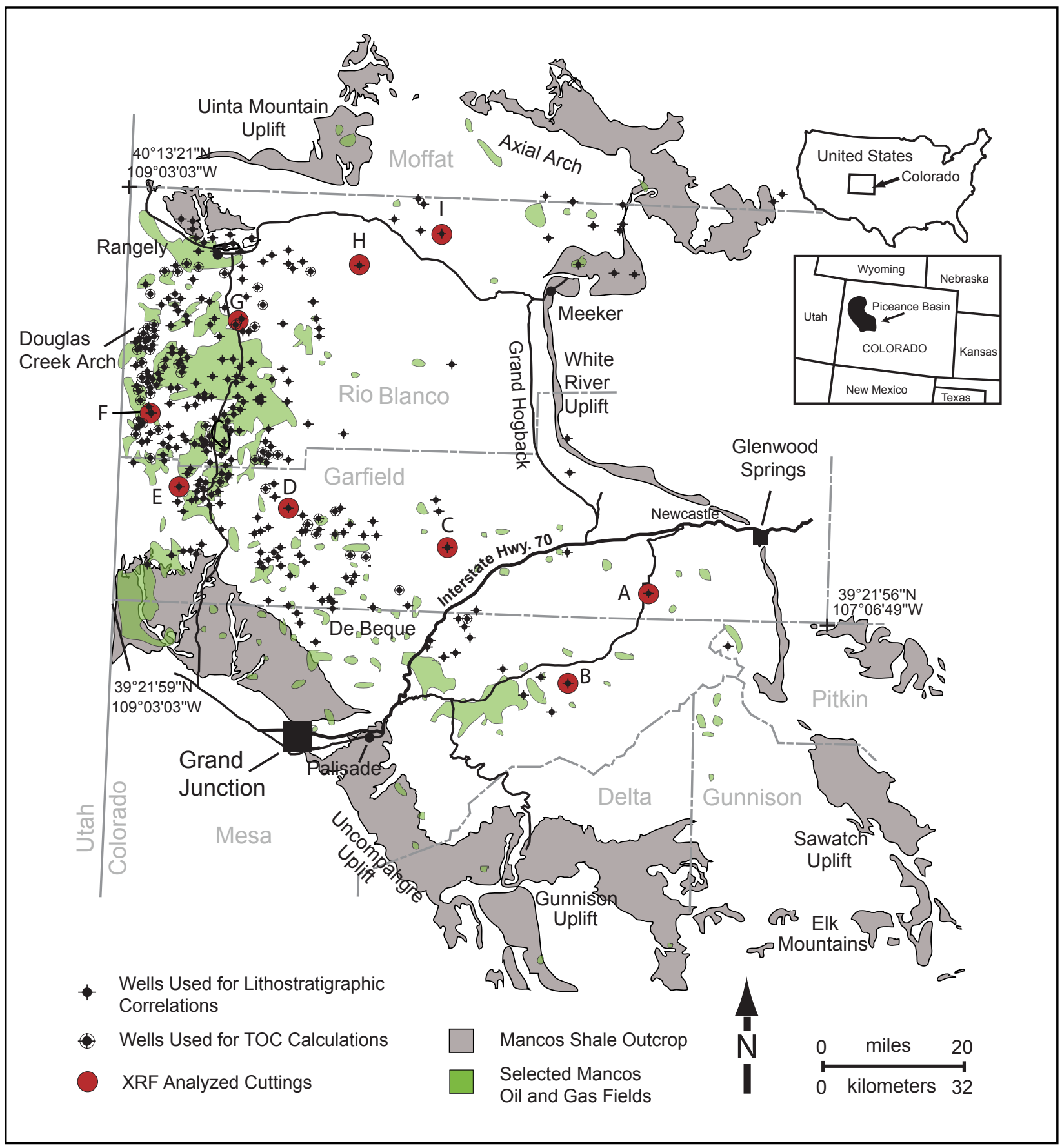

Figure 1. Map of Piceance Basin showing Mancos Shale outcrops, major Mancos Shale oil and gas fields, and wells used for this study. XRF analyzed cuttings from wells labeled A through I listed in adjoining Table 1. Modified from Hoak and Klawitter (1997) and Pranter et al. (2009). Mancos Shale oil and gas fields from Kirschbaum (2003). 


\begin{tabular}{|c|c|c|c|c|c|c|c|c|c|}
\hline 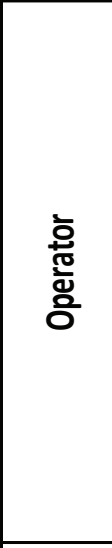 & $\begin{array}{l}\overrightarrow{\overline{0}} \\
\overline{\overline{0}} \\
\text { 을 }\end{array}$ & 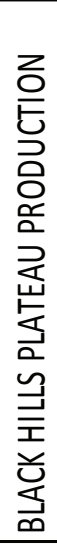 & 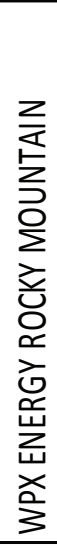 & 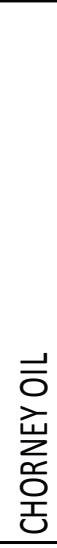 & 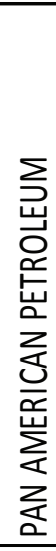 & 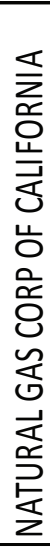 & 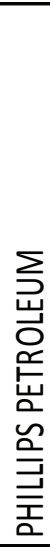 & 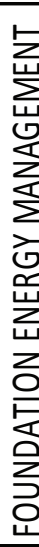 & 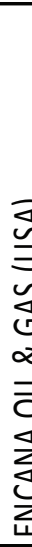 \\
\hline 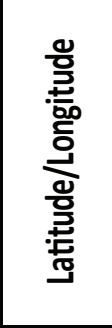 & 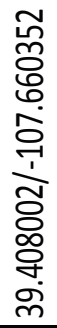 & 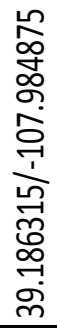 & 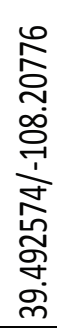 & 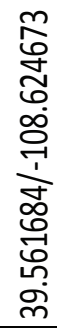 & 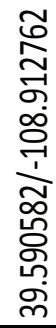 & 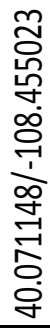 & 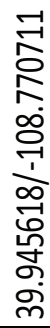 & 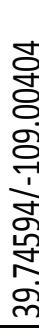 & 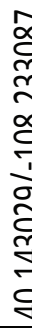 \\
\hline 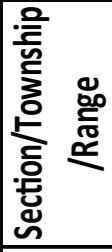 & 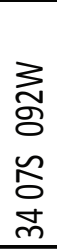 & $\begin{array}{l}3 \\
\text { 영 } \\
\text { 음 } \\
\text { 늠 }\end{array}$ & 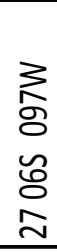 & 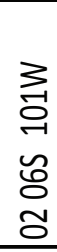 & $\begin{array}{l}3 \\
\text { o } \\
\text { - } \\
\text { 㟔 } \\
\text { 兄 }\end{array}$ & 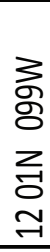 & 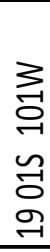 & $\begin{array}{l}\widetilde{\gamma} \\
\bar{m}\end{array}$ & 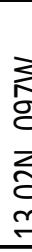 \\
\hline 흥 & 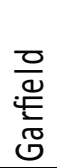 & 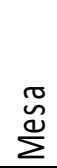 & 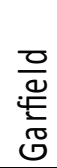 & 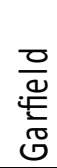 & 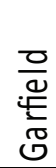 & $\begin{array}{l}\stackrel{O}{c} \\
\frac{0}{0} \\
\frac{0}{0} \\
. \frac{0}{x}\end{array}$ & $\begin{array}{l}\frac{8}{c} \\
\frac{0}{\infty} \\
\frac{0}{x}\end{array}$ & $\frac{8}{\frac{c}{c}}$ & $\frac{s}{a}$ \\
\hline 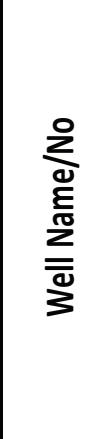 & 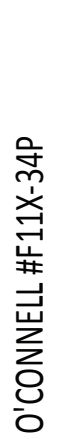 & 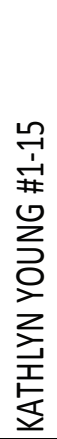 & 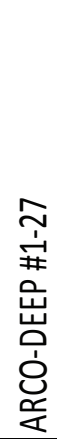 & 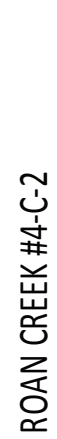 & 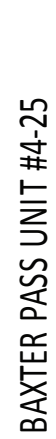 & 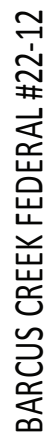 & 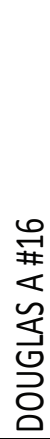 & 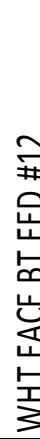 & 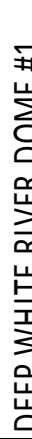 \\
\hline$\frac{\frac{\#}{\bar{\alpha}}}{\overline{\bar{d}}}$ & 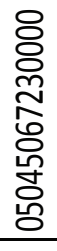 & 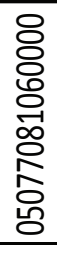 & 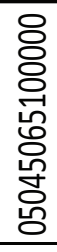 & 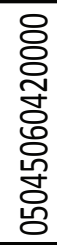 & 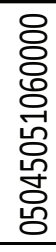 & 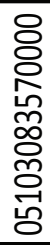 & 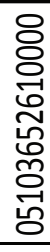 & 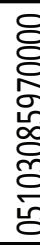 & 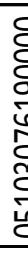 \\
\hline 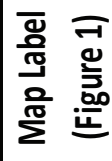 & $<$ & $\infty$ & $\cup$ & ص & ш & ப & ৩ & I & - \\
\hline
\end{tabular}


produced by this method were used to evaluate the stratigraphic changes of source-rock richness, and data of this resolution have not been previously reported for the Niobrara Member of the Mancos Shale interval in this area.

This thesis addresses: 1) how chemostratigraphy was used as an independent technique for stratigraphic correlation, 2) how chemostratigraphic zonations relate to lithostratigraphic units, and 3) how organic richness varies spatially throughout the study area. Together, the chemostratigraphic and petrophysical techniques allow a better understanding of the source- and reservoir-rock potential of the Niobrara Member. The results of this study establish a database from which correlations can be made for the Niobrara Member in the Piceance Basin. Additionally, some implications of the changes in elemental composition and organic richness are investigated; changes in the depositional environment (e.g., oxygenation level and terrestrial input) of the Niobrara Member are interpreted, and a qualitative approach to interpret relative changes in rock brittleness is discussed, which would aid in assessing variations in potential reservoir quality. Moreover, this study aims to provide direction and insight for further chemostratigraphic study and petrophysical interpretations of this interval.

\section{TECTONIC AND STRATIGRAPHIC SETTING}

\section{Geologic History}

During the Late Cretaceous, an epeiric seaway, the Western Interior Seaway, covered the central part of North America from the Gulf of Mexico to northern Canada (Kauffman, 1977; Kauffman and Caldwell, 1993). The seaway inundated an asymmetric foreland basin, the Western Interior Basin, which resulted in the deposition of widespread marine sediments (Figure

2) (Longman et al., 1998). The process of mountain building from the tectonically active Sevier 


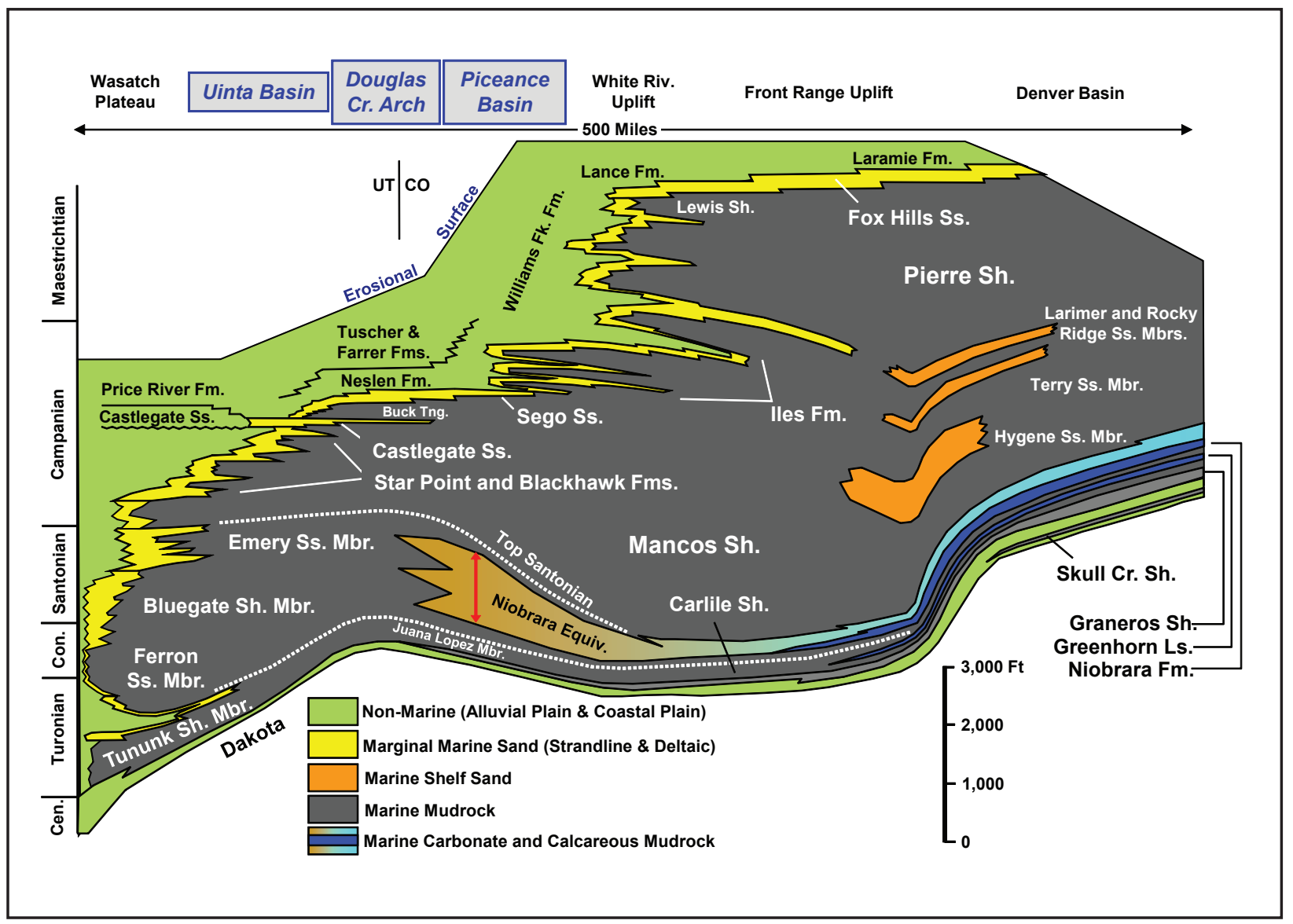

Figure 2. Cross section of Cretaceous strata deposited in eastern Utah and western Colorado. Niobrara Member of Mancos Shale study interval is shown with red bar. From Cole (2008), modified from Dyman et al. (1994). 
Orogenic belt to the west supplied coarse siliciclastic sediments into the western portion of the seaway. Eastward-flowing currents transported finer grained siliciclastic silts and muds onto the low relief eastern part of the seaway (Longman et al., 1998; Finn and Johnson, 2005). Across the western part of the foreland basin, a "complex pattern of intertonguing marine and nonmarine" sediments was deposited (Finn and Johnson, 2005, p. 3). Westward-thinning tongues of marine shale and siltstone characterize the marine deposits, whereas eastward-thinning clastic wedges of sandstone, siltstone, shale, and coal are representative of the nonmarine deposits (Figure 2) (Dyman et al., 1994; Finn and Johnson, 2005; Cole 2008). On the eastern shelf of the seaway, where the influx of siliciclastic sediments was restricted and conditions were favorable for carbonate deposition, a variety of carbonate sediments ([many] rich in coccolith debris and planktonic foraminifers) accumulated (Roberts and Kirschbaum, 1995; Longman et al., 1998; Finn and Johnson, 2005). The Niobrara Formation (as named in the eastern part of the seaway), which is part of a sequence of "thick Upper Cretaceous marine shales that blanket the entire Western Interior of North America" (Johnson, 2003, p.6) was deposited during a time of major marine transgression.

During the Laramide Orogeny, a period of mountain building in western North America that started in the Late Cretaceous (approximately $70 \mathrm{Ma}$ ) and ended in the Eocene (approximately 55 to $40 \mathrm{Ma}$ ), a series of north-trending uplifts and intermontane structural basins formed. In the United States, these basins occur primarily in the central Rocky Mountains from Colorado and Utah to Montana. The area presently occupied by the Piceance Basin was partitioned during Laramide tectonism from the larger pre-existing Western Interior foreland basin (Johnson and Flores, 2003; DeCelles, 2004). 
The Piceance Basin is a highly asymmetrical northwest-trending structural depression located entirely in northwestern Colorado and is part of the Colorado Plateau physiographic province. The basin is bounded by the Rangely Anticline and Axial Arch to the north, the Grand Hogback Monocline to the east, the Gunnison Uplift, Elk Mountains, and Sawatch Uplift to the south and southeast, the Uncompahgre uplift to the southwest, and the Douglas Creek Arch to the west (Figure 1) (Johnson, 1989).

This study focuses on the Niobrara Member of the Mancos Shale and equivalent rocks in the Piceance Basin. The study area covers part or all of these counties: Moffat, Routt, Rio Blanco, Garfield, Mesa, Delta, and Pitkin, over an area of approximately 6,000 $\mathrm{mi}^{2}\left(15,540 \mathrm{~km}^{2}\right)$.

\section{Review of Niobrara Stratigraphy and Lithology}

The Niobrara Formation was first described by Meek and Hayden (1861) for exposures near the mouth of the Niobrara River in Nebraska. Longman et al. (1998) thoroughly reviewed the various published descriptions of the Niobrara stratigraphy in the Western Interior Seaway of the Rocky Mountain Region. In the eastern part of the seaway, the Niobrara Formation is formally divided into two members: the lower Fort Hays Limestone Member and the overlying Smoky Hill Member (e.g. in Kansas and in the Denver Basin, in eastern Colorado) (Landon et al., 2001). These stratigraphic intervals were correlated northward and westward from the Denver Basin. In the western part of the seaway (that includes the Piceance Basin), stratigraphic correlations become difficult "due to the disappearance of distinctive log markers and the relatively uniform $\log$ character in the thick shaly section of the Mancos" (Longman et al., 1998, p. 138). 
In the westernmost part of the Piceance Basin, primarily at Rangely, production from fractured Cretaceous shales has been referred to as Mancos production (Vincelette and Foster, 1992). However, log correlations indicate that most of this production is from the "lower third of the Mancos, which is the Niobrara Formation equivalent and has a lithology typical of the Niobrara Formation in areas farther east" (Vincelette and Foster, 1992, p. 233). In the southern Piceance Basin, the Niobrara Member is underlain by the Montezuma Valley and Juana Lopez Members of the Mancos Shale (Figure 3). This nomenclature conforms with usage by Ball et al. (2009), Merewether et al. (2006), and Gustason (E. R., 2013, personal communication). Over the extent of the basin, a consistent and distinctive well-log marker below the Niobrara Member corresponds to the Juana Lopez Member of the Mancos Shale. The Niobrara Member is overlain by the Prairie Canyon Member (Cole, 1997). To the west of the Piceance Basin, the Niobrara Member is likely equivalent to the Blue Gate Shale (Johnson, 2003; Rogers, 2012). The Niobrara Member is considered to be Coniacian to Campanian in age (Scott and Cobban, 1964), and Ball et al. (2009) show that the base of the formation corresponds to the inoceramid biozone of

\section{Cremnoceramus erectus.}

The Niobrara Formation and stratigraphically equivalent strata contain a spectrum of lithologies ranging from limestone and chalks to marls and less calcareous shales (Longman et al., 1998). In the eastern part of the seaway, typical Niobrara Formation lithologies are chalks and limestone (Finn and Johnson, 2005). A gradual westward decrease in chalk and other carbonate components characterizes the lithology variation of the Niobrara Formation as it grades into the Niobrara Member of the Mancos Shale (Longman et al., 1998). This is considered to be the result of a closer proximity to the Sevier thrust belt to the west, which constitutes the primary detrital source (Longman et al., 1998). In the western part of the seaway which includes 


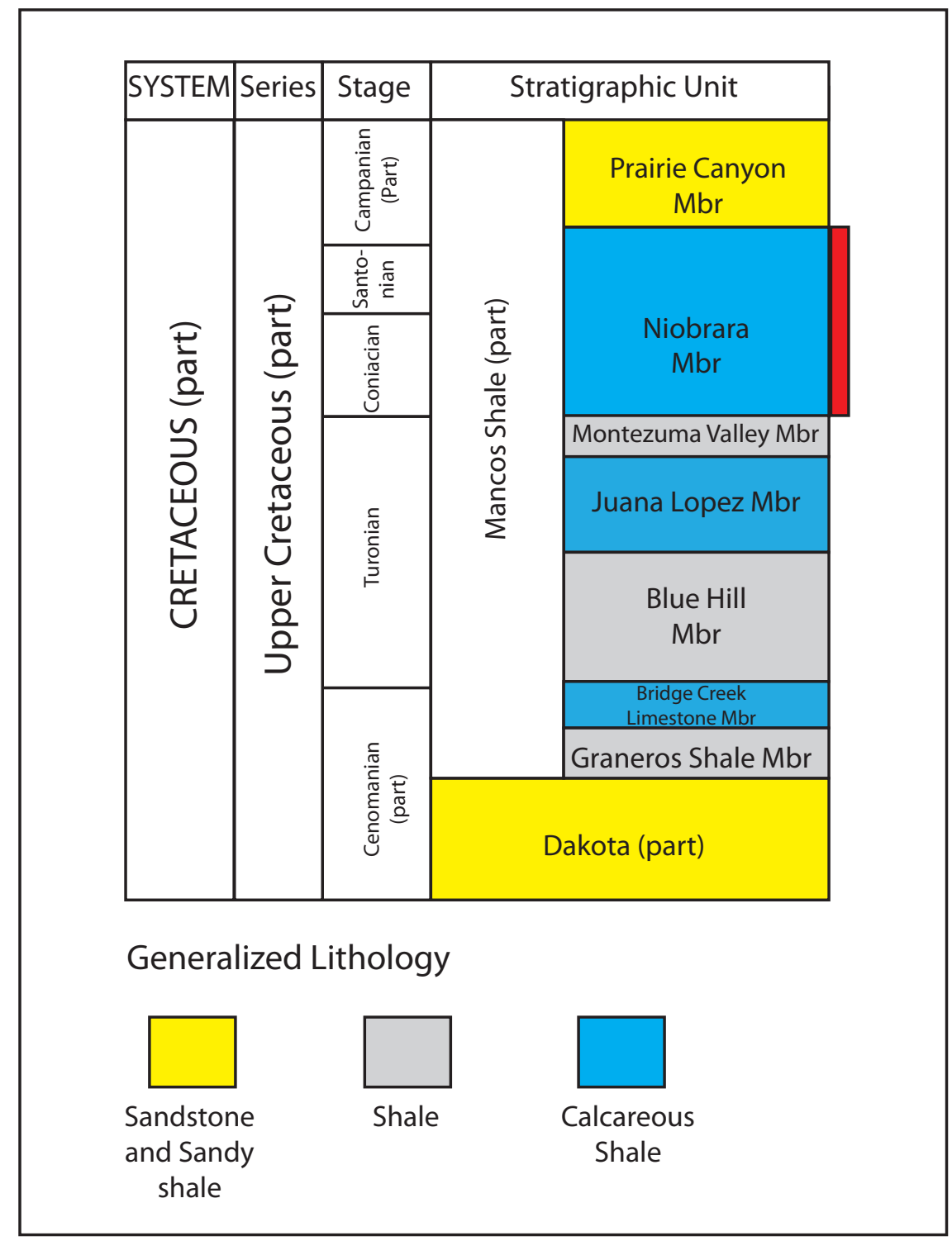

Figure 3. Generalized stratigraphic column and lithologic section showing nomenclature used in this study. The interval of study is shown with a red bar. Nomenclature adopted from Merewether et al. (2006) tied to Ball et al. (2009) and Gustason (pers. comm., 2013). 
the study area, typical Niobrara Member calcareous (limestone and chalk) facies grades laterally into calcareous shale (marl) and weakly to noncalcareous shale of the Mancos Shale. However, "the limits of the calcareous facies of the Niobrara [Formation] are not well mapped" (Finn and Johnson, 2005, p. 6).

\section{METHODOLOGY}

\section{Chemostratigraphic Analysis}

Whole-rock quantitative data were acquired for 40 elements: 8 major elements (Al, Si, Ti, $\mathrm{Fe}, \mathrm{Mn}, \mathrm{Ca}, \mathrm{Mg}$, and $\mathrm{K}$ ) and 32 minor and trace elements (Ag, $\mathrm{As}, \mathrm{Au}, \mathrm{Ba}, \mathrm{Bi}, \mathrm{Cd}, \mathrm{Cl}, \mathrm{Co}, \mathrm{Cr}$, Cs, Cu, Hg, Mo, Nb, Ni, P, Pb, Pd, Rb, S, Sb, Sc, Se, Sn, Sr, Te, Th, U, V, W, Zn, and Zr). Counting times were 30 seconds each on the low- and main-energy filters and 45 seconds on the light-filter setting (105 seconds total counting time) for the "mining" analysis mode (used to detect metals), and 45, 35, and 30 seconds respectively on the low-, main-, and high-filter settings (110 seconds total counting time) for the "soils" analysis mode (used to detect elements typically associated with soils). Elements Ti to U were analyzed using the low-, main-, and highfilter settings, and the light-filter setting was used to analyze $\mathrm{Mg}$ to S. Measurements in the "mining" mode were recorded in weight percent (wt. \%), and those in the "soils" mode in parts per million (ppm). Precision and repeatability of the major-, minor-, and trace-element data are detailed in Appendix A.

\section{Total Organic Carbon and $\triangle \log R$ Technique}

Several well-log techniques have been developed for identifying and calculating total organic carbon (TOC) of subsurface strata (Appendix B, Table B-1). The $\Delta$ log R method of 
Passey et al. (1990) uses the well-log curve separation resulting from the overlay of properly scaled porosity and resistivity logs to determine TOC. When plotted on the same log track, the porosity and resistivity curves parallel each other and can be overlain in a non-source rock. For hydrocarbon-bearing (reservoir) or organic-rich non-reservoir intervals, a separation between the two curves, termed " $\Delta \log R$ ", occurs. A gamma-ray log can be used to differentiate between lithologies and to eliminate reservoir sections from the analysis. In an immature source rock, the $\Delta \log \mathrm{R}$ separation is primarily caused by the porosity curve responding to the low-density organic matter. However, in a mature source rock, the separation results from the additional response of the resistivity log to the presence of hydrocarbons (Passey et al., 1990) (Figure 4). Three curves (sonic, bulk density, and neutron porosity) produce a response that can mimic an increase in porosity, but the use of a sonic/resistivity combination is recommended because it is shown to be more accurate than the density/resistivity and neutron/resistivity combinations (Passey et al., 1990).

The TOC content in mature source rocks is calculated using the $\Delta \log \mathrm{R}$ separation (measured in logarithmic resistivity cycles) and by applying a maturity factor expressed as LOM (level of organic metamorphism). Two empirical equations are used to quantify TOC:

$\Delta \log \mathrm{R}=\log 10\left(\mathrm{R} / \mathrm{R}_{\text {baseline }}\right)+0.02 *\left(\Delta \mathrm{t}-\Delta \mathrm{t}_{\text {baseline }}\right)$

$\mathrm{TOC}=(\Delta \log \mathrm{R}) * 10^{\wedge}(2.297-0.1688 * \mathrm{LOM})$

$\mathrm{R}$ is the measured deep resistivity value in ohm.m and $\Delta \mathrm{t}$ is the measured transit time in $\mu \mathrm{s} / \mathrm{ft}$. $\mathrm{R}_{\text {baseline }}$ and $\Delta \mathrm{t}_{\text {baseline }}$ are the respective resistivity and transit-time values when the curves are overlain (baselined) in a non-source rock. 


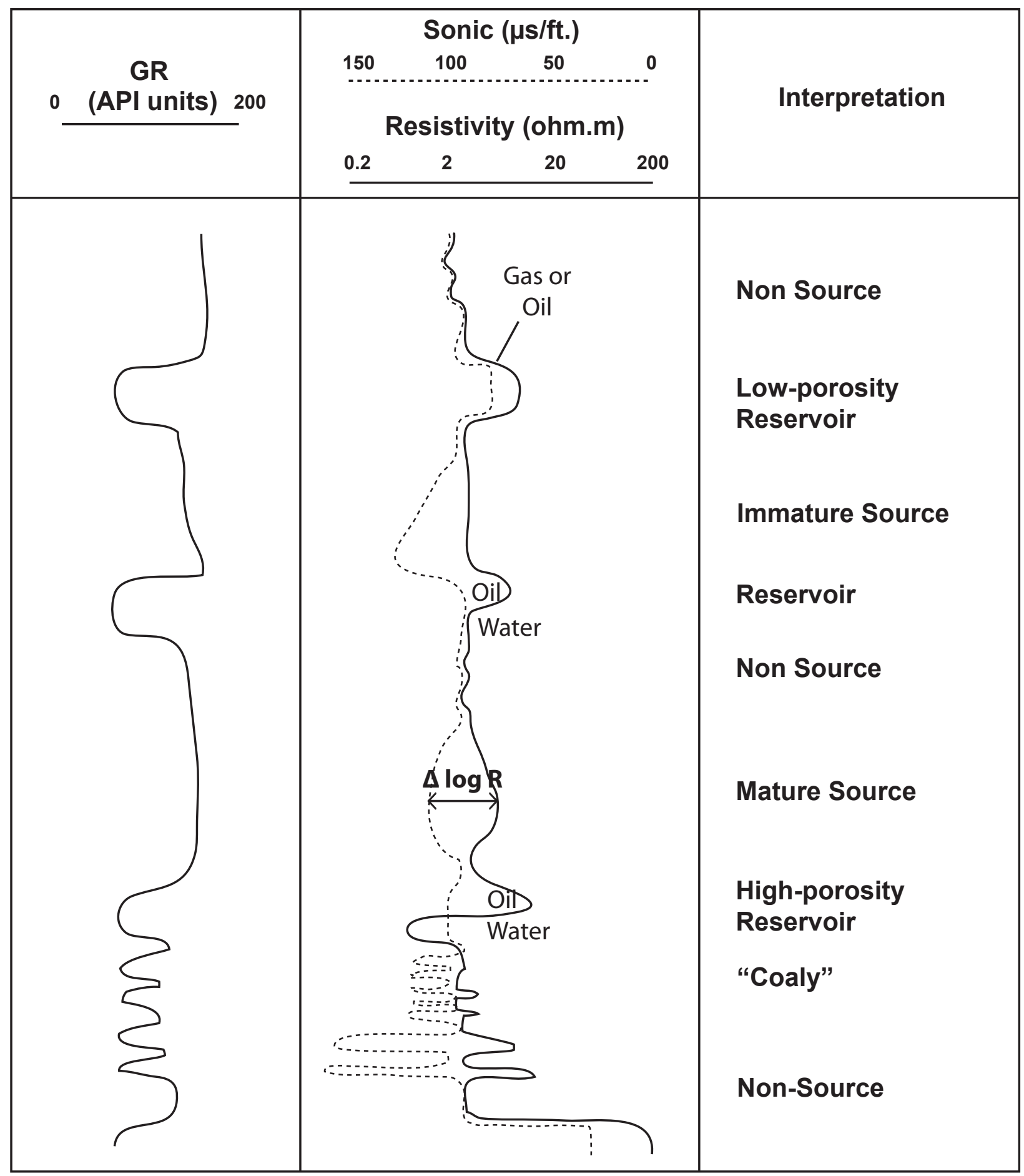

Figure 4. Schematic guide for interpretating various $\log$ motifs observed on $\Delta \log R$ overlays. Modified from Passey et al. (1990). 
Differential transit-time, or sonic (DT), and deep-induction resistivity logs (ILD or LLD) were used (as recommended by Passey et al., 1990) to solve for TOC in 68 wells (Figure 1; Appendix B, Table B-2).

The first step in applying the $\Delta \log \mathrm{R}$ technique is to adjust the sonic (DT) and resistivity (ILD or LLD) logs such as their relative scaling is $-100 \mu \mathrm{s} / \mathrm{ft}(-328 \mu \mathrm{s} / \mathrm{m})$ per two logarithmic resistivity cycles. The two curves are then overlain and baselined over a fine-grained, "nonsource" interval. A baseline condition is identified when the two log profiles directly track each other over a considerable depth range (e.g. $400 \mathrm{ft}$ [121.9 m]) (Passey et al., 1990). Once the baseline is established, organic-rich zones are identified by 1) the separation and 2) non parallelism of the two curves (Figure 4). A TOC profile is then constructed, first by quantifying the $\Delta \log \mathrm{R}$ separation (equation 1), and then by calculating TOC (equation 2) when the maturity factor (LOM) is determined.

LOM is a thermal maturity indicator that "describes how far the thermal metamorphism of sedimented organic matter has progressed during subsurface burial" (Hood et al., 1975, p. 986). It is a linear scale used for numerically correlating different indicators of organic metamorphism, such as coal rank, carbonization of structured organic matter, and vitrinite reflectance $(\%$ Ro) .

Thermal maturity data used in this study are from average \%Ro values $(\mathrm{N}=81$ samples from 18 wells, at sample frequency ranging between $<100 \mathrm{ft}[<30.5 \mathrm{~m}]$ and $970 \mathrm{ft}[295.7 \mathrm{~m}]$; USGS Core Research Center) for the Niobrara Member interval converted to LOM using a rearranged LeCompte and Hursan's (2010) formula (Appendix B; Cardneaux, 2012). To determine LOM values at each well used for TOC calculations, known LOM values from 18 wells were 
used to map the LOM distribution across the study area and assign values for wells at which no published maturity data were available.

In addition, because baselining the transit-time and resistivity curves considers the baselined interval as "zero TOC", "background" TOC must be added back to the TOC calculated from equation (2) (Passey et al., 1990). The average TOC in shales worldwide generally exceeds 0.8 wt.\% (Tissot and Welte, 1984) and 1 wt.\% TOC is used in this study to account for this "background" TOC. Because the $\Delta$ Log R technique can yield high anomalous $\Delta$ Log $\mathrm{R}$ separation values (not related to an increase in both resistivity and sonic values), a resistivity/sonic log cross-plot was used to qualitatively eliminate potentially anomalous TOC from the analysis. By using a lower TOC cutoff value of $1 \mathrm{wt} . \%$, only TOC associated with both high resistivity and high sonic values is kept in the analysis (detailed in Appendix B, Figure B-2) (M. Connolly, 2013, personal communication). Figure 5 provides an example of the application of the $\Delta \log \mathrm{R}$ technique for the South Baxter Pass Unit \#2-20 well in Garfield County, Colorado.

\section{SUBSURFACE STRATIGRAPHY}

The subsurface stratigraphy of the Niobrara Member of the Mancos Shale in northwestern Colorado has previously been described by Vincelette and Foster (1992), Longman et al. (1998), Fisher (2007), Kuzniak (2009), and Rogers (2012), although subdivisions of the Niobrara Member in the Piceance Basin remain as informal nomenclature. In this study eight lithostratigraphic units are defined and correlated across much of the basin based on changes in gamma-ray and deep-resistivity logs (Figure 6; Appendix C). These units are termed from the 


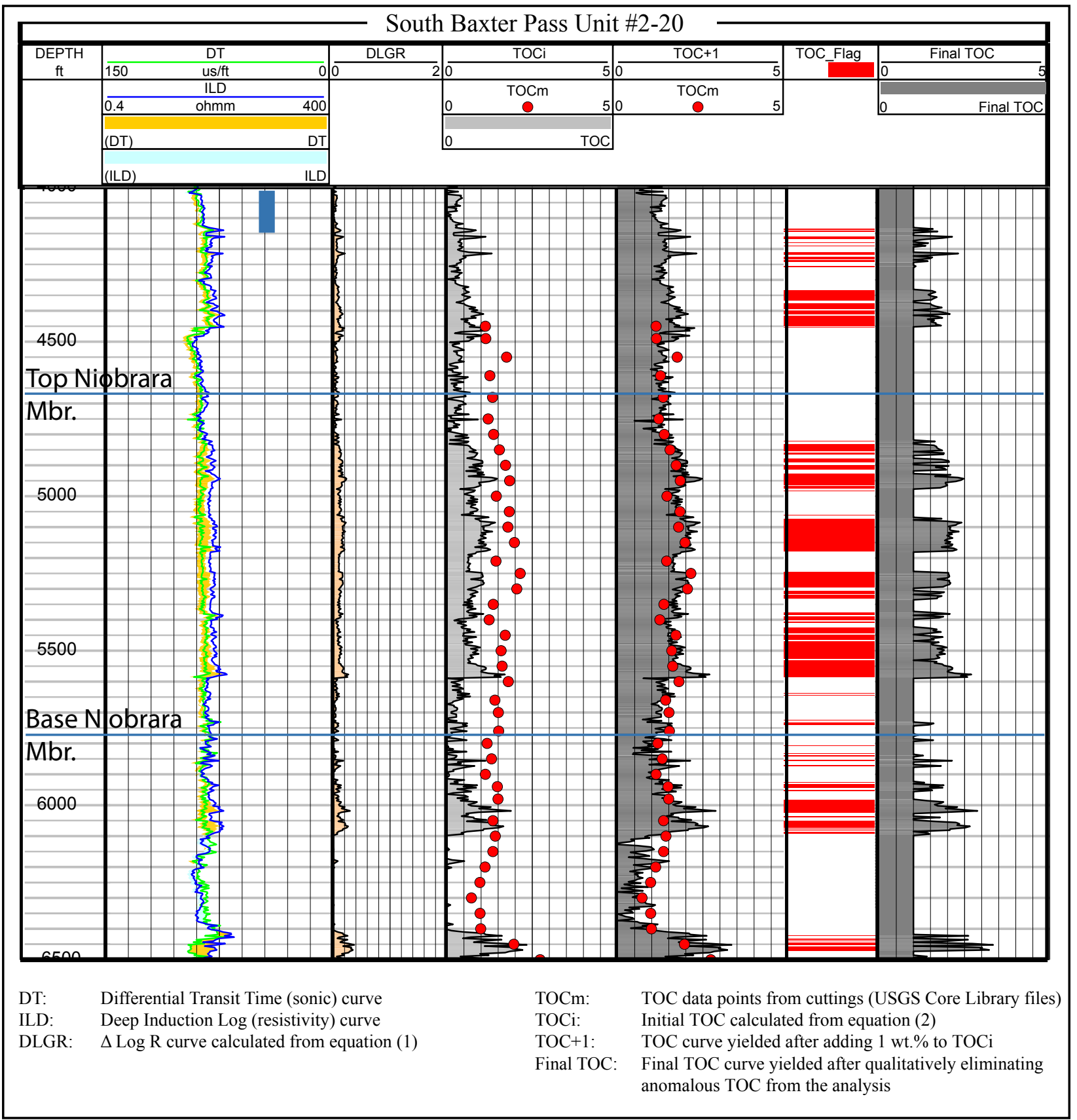

Figure 5. $\Delta$ Log R technique (Passey et al., 1990) applied to "South Baxter Pass Unit \#2-20" (API\#: 05-045-05112) well in western Garfield county. The first log track shows the overlay of the sonic and the resistivity logs. The logs are properly scaled and baselined over a "non-source" interval. A portion of the interval over which the baseline was established is shown with a blue bar in the first track. The orange filling highlights the $(\Delta \log \mathrm{R})$ separation between the two curves. The second log track shows the " $\Delta \log$ R" curve. The third and fourth log tracks show the intial TOC and the TOC +1 curves respectively, as they both compare to TOC data points (from USGS Core Library data files). The TOC Flag log track highlights in red intervals over which the $\Delta \log \mathrm{R}$ separation is likely due to the increase in both the DT and the ILD values (detailed in Appendix B). The Final TOC curve is the curve yielded after potentiallyanomalous TOC is removed from the analysis. 


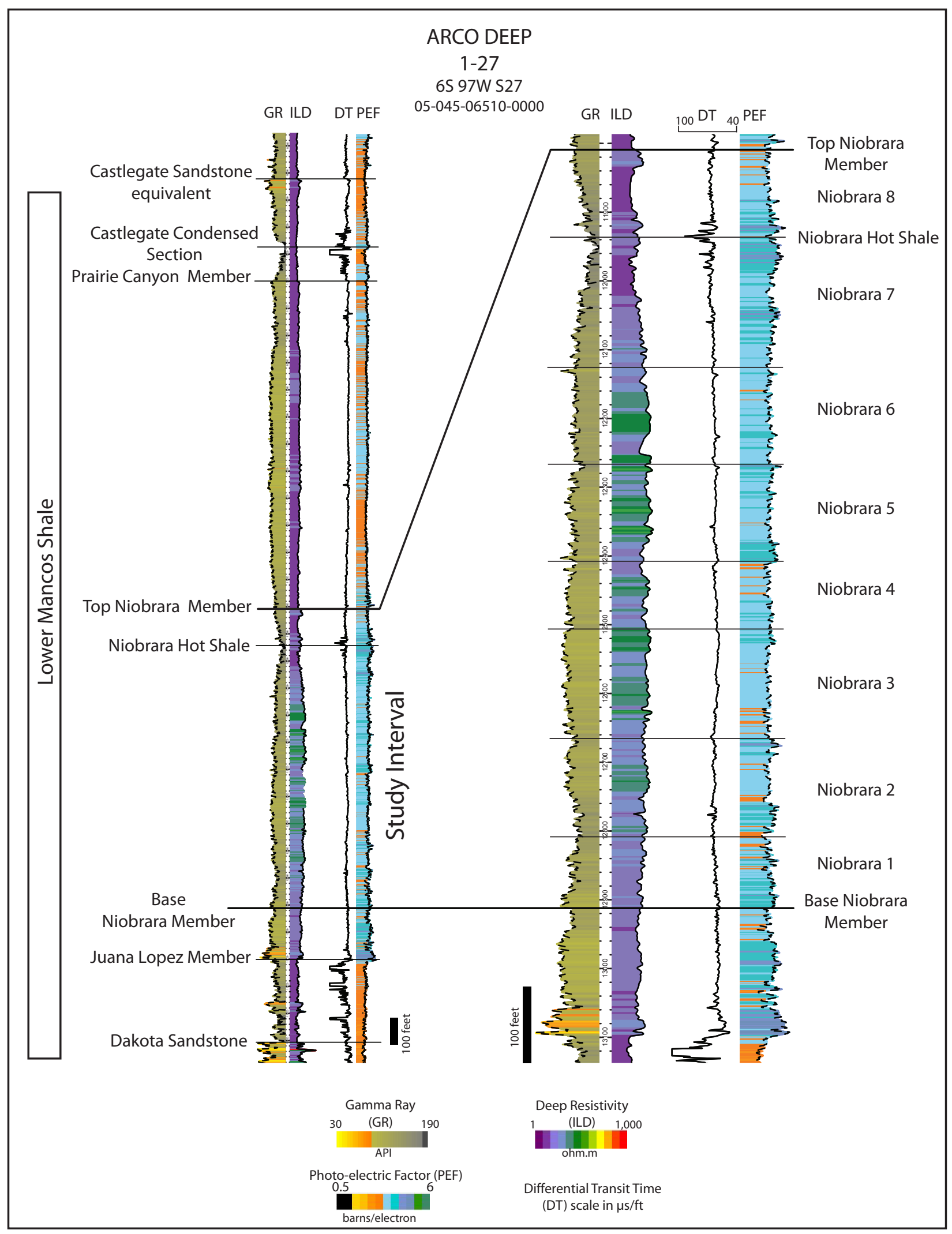

Figure 6. Type Log for the Niobrara Member in the Piceance Basin. Eight lithostratigraphic units are identified. Location of well is shown on Figure 1 (labelled C). 
base to the top (oldest to youngest) of the Niobrara Member as Niobrara 1 to 8 . The Niobrara Member ranges in thickness between less than $750 \mathrm{ft}(228.6 \mathrm{~m})$ in the southeast to more than $1700 \mathrm{ft}(518.16 \mathrm{~m})$ in the northwest of the Piceance Basin. In general, all Niobrara Member lithostratigraphic units thicken to the northwest (Figure 7; Appendix C).

The base of the Niobrara Member as defined in this study is a laterally consistent surface across the Piceance Basin that marks a shift on the gamma-ray curve with lower values recorded in the underlying units. Where the gamma-ray character change was less readily identifiable, the base of Niobrara Member was picked at an increase in deep resistivity values (from lower values below to higher values above). Within the Niobrara Member, the key surfaces ("markers") that were used for stratigraphic correlation correspond to sharp shifts on the gamma-ray curve from lower values below to higher values above. The character of the gamma-ray log was more extensively used for correlating key surfaces, whereas the deep-resistivity log proved less helpful over large areal extents. All stratigraphic markers are generally well-retained across the study area, although log characters of the tops of lithostratigraphic units Niobrara 1, Niobrara 3, and Niobrara 7 appear to be more readily identifiable across the entire study area. The "Niobrara Hot Shale" marker (top of Niobrara 7) is regionally very consistent and was used to identify the Niobrara Member within the Lower Mancos Shale, and the high gamma-ray values recorded at this surface can be attributed to the presence of a regionally organic-rich interval. The top of the Niobrara Member is picked in this study at the first decrease of a highly-resistive marker which is interpreted to correspond to the top of the calcareous lithology (Haskett, 1959; Vincelette and Foster, 1992; Finn and Johnson, 2005; Rogers, 2012). 


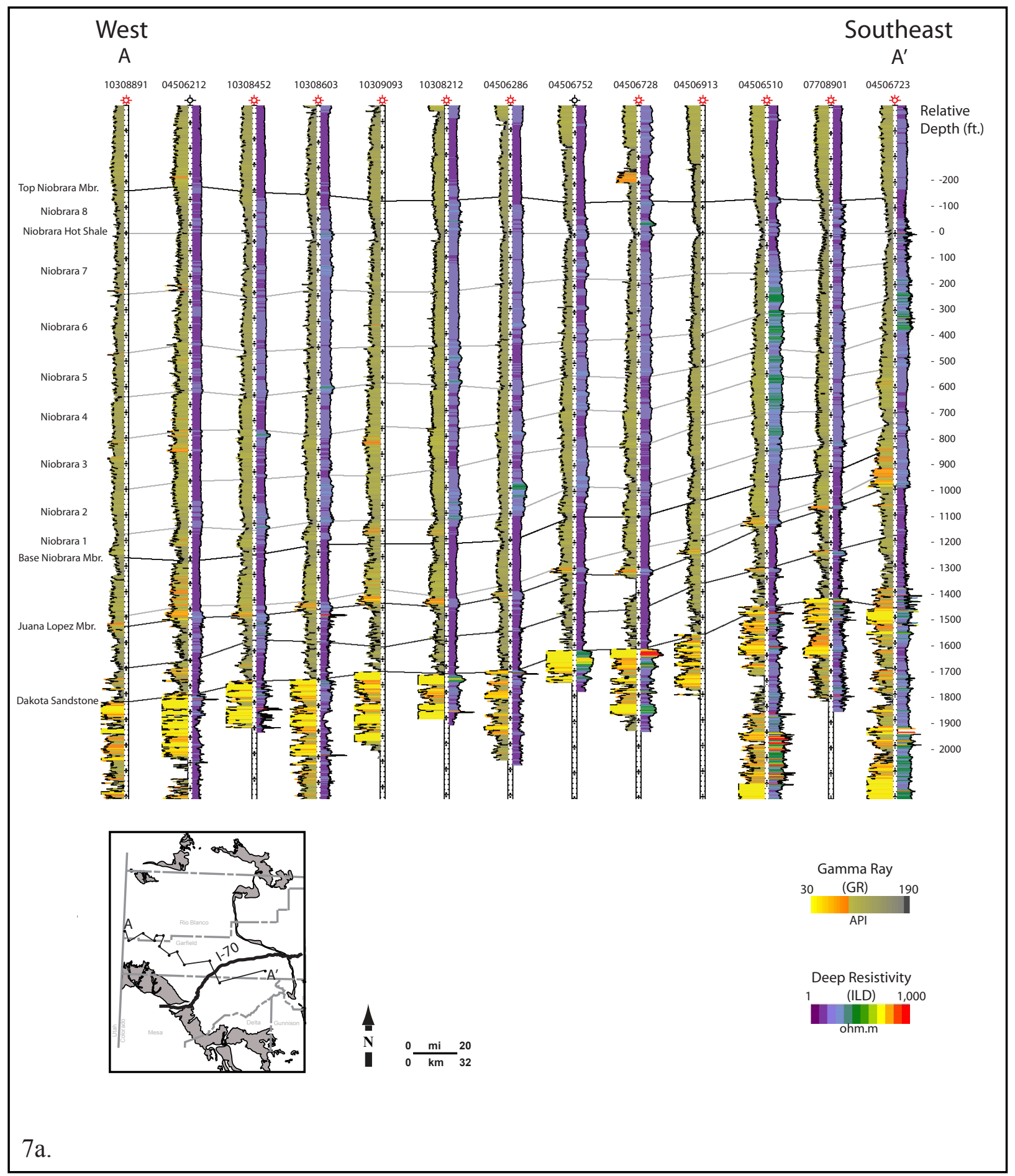




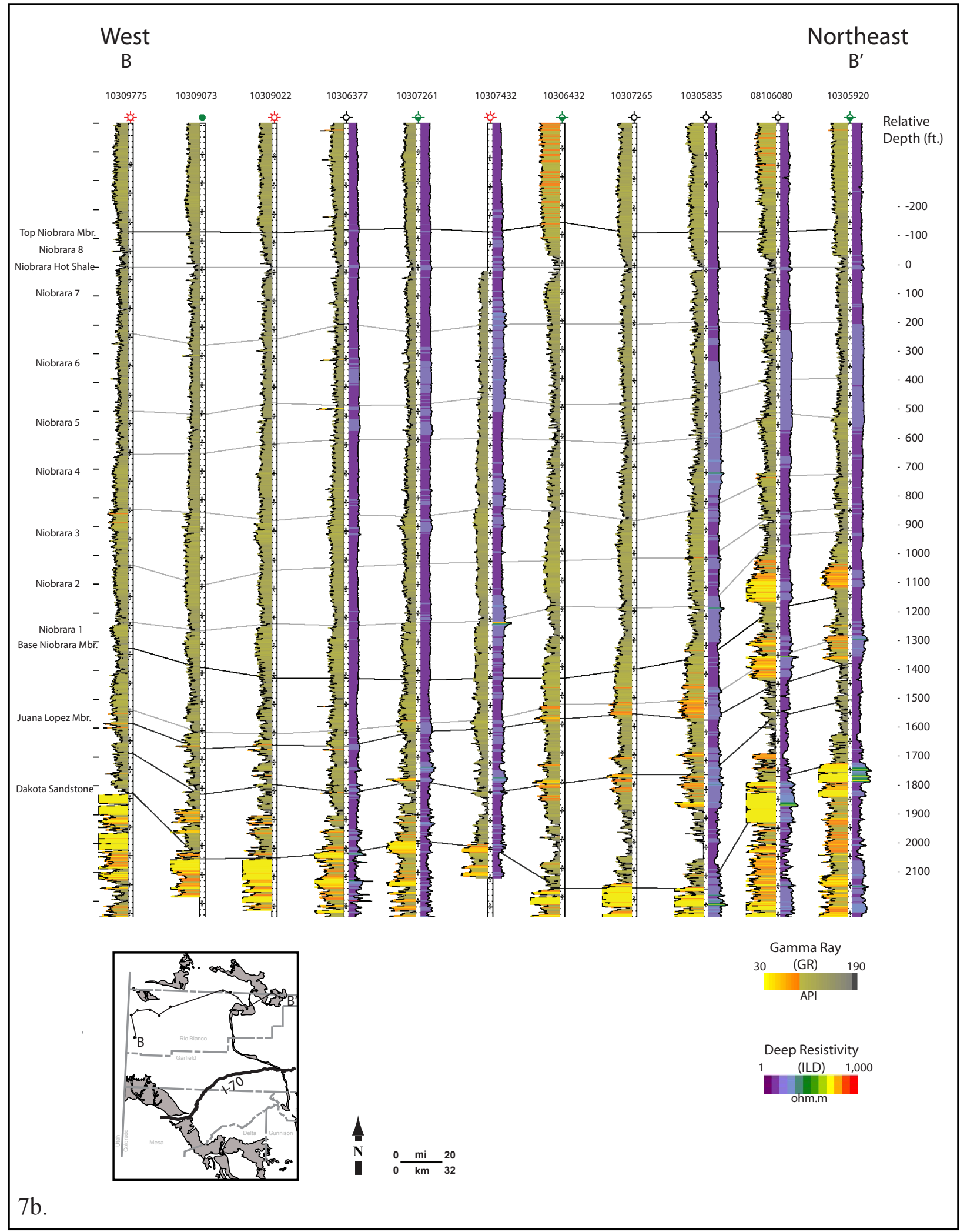

Figure 7. Cross sections AA' (7a.) and BB' (7b.) flattened on top of the "Niobrara Hot Shale" marker. Space between wells is equal and not representative of actual distances. Numbers at log tops correspond to well API numbers. Eight lithostratigraphic units (Niobrara 1 to Niobrara 8) are identified from the logs. In general, all units thicken to the northwest. 
Based on interpretations made from well-log characteristics, all units appear to be similar in terms of lithologic composition (non-calcareous, calcareous, and very calcareous shale), varying primarily in shale/carbonate content and organic richness (Appendix C).

\section{ELEMENTAL CHEMOSTRATIGRAPHY}

\section{Chemostratigraphic Zonation}

Chemostratigraphic zonation is defined as the subdivision of sedimentary intervals based on changes in inorganic geochemical composition (Pearce et al., 2008). In this study, abundance profiles (or geochemical logs) of elemental data are plotted versus depth. Elemental data are expressed as absolute concentrations (ppm or wt.\%) or as a ratio of one element against another. Analytical data from the ratio plots highlight compositional changes associated with mineralogy (Pearce et al., 2008), and normalizing the data against $\mathrm{Al}$ values compensates for changes in geochemistry that can be attributed to grain-size variations (Pearce et al., 2008). The subdivision of a sedimentary interval into chemostratigraphic zones was established on the basis of the changing morphology (log motifs) of the geochemical logs.

$\mathrm{X}$-ray fluorescence (XRF) data were acquired for 40 elements from well cuttings. However, many element concentrations fell below the quantification limits of the instrument (Ag, $\mathrm{Au}, \mathrm{Bi}, \mathrm{Cd}, \mathrm{Cl}, \mathrm{Co}, \mathrm{Hg}, \mathrm{Mg}, \mathrm{Nb}, \mathrm{Ni}, \mathrm{Pb}, \mathrm{Pd}, \mathrm{Sb}, \mathrm{Se}, \mathrm{Sn}, \mathrm{U}$, and $\mathrm{W}$ ), and only certain detected elements (with measurement error $<20 \%$ ) were used to develop geochemical fingerprints for each zone. These elements, referred to as chemostratigraphic index elements, are selected on the basis of their systematic variation as they relate to stratigraphy. From well data, distinctive trends can be recognized because changes in elemental composition with depth are directly related to stratigraphy (Ratcliffe et al., 2007). 
The Kathlyn Young \#1-15 well (API\#: 05-077-08106; 15 10S 95W; having cuttings sampling interval of $10 \mathrm{ft}[3.05 \mathrm{~m}]$ over complete Niobrara Member) is used as the chemostratigraphic reference well for the Niobrara Member in the Piceance Basin. Key geochemical profiles of ten index elements and element ratios were used to independently define six chemostratigraphic zones within the Niobrara Member interval (Figure 8; Appendix D). The chemostratigraphic zones are designated stratigraphically upward as CN1 to CN6. Representative elements and element ratios used for geochemical zonation are: $\mathrm{Ca}, \mathrm{Si}, \mathrm{Si} / \mathrm{Al}, \mathrm{Al}$, $\mathrm{Fe}, \mathrm{K} / \mathrm{Al}, \mathrm{Mo}, \mathrm{Cr}+\mathrm{V}$, Ti, and Zr.

Overall, four calcium-enriched zones are identified (CN1, CN2, CN4, and CN6) (Figure 8). In general, $\mathrm{Ca}$ and $\mathrm{Si}$ geochemical logs show opposite trends, and this observation is most apparent in the O'Connell well (Figure 1; Appendix D). Si, Al, Fe, Ti, and Zr logs generally track each other, although some exceptions exist locally. Similarly, curves of Si/Al and K/Al closely track each other.

Chemostratigraphic Zone $\mathrm{CN} 1$ is the first calcium-enriched zone and begins with high values of $\mathrm{Ca}$ (up to $12 \mathrm{wt} . \%$ in the O'connell well) that gradually decrease upward. The base of this zone (base of Niobrara Member) is marked by higher $\mathrm{Si} / \mathrm{Al}$ and $\mathrm{K} / \mathrm{Al}$ values. Overall, curves of $\mathrm{Si} / \mathrm{Al}$ and $\mathrm{K} / \mathrm{Al}$ show an increasing-upward trend, whereas values $\mathrm{Si}, \mathrm{Fe}, \mathrm{Mo}, \mathrm{Cr}+\mathrm{V}$, $\mathrm{Ti}$, and $\mathrm{Zr}$ slightly increase upward. Al values remain relatively constant in most wells. The top of this zone is characterized by an abrupt decrease in $\mathrm{Si}$ and $\mathrm{Ti}$ values and an increase in $\mathrm{Si} / \mathrm{Al}$ and $\mathrm{K} / \mathrm{Al}$ values.

Chemostratigraphic Zone CN2 is the second calcium-enriched zone. Overall, values of $\mathrm{Si} / \mathrm{Al}$ and $\mathrm{K} / \mathrm{Al}$ slightly increase upward, and this change is most pronounced in Baxter Pass 


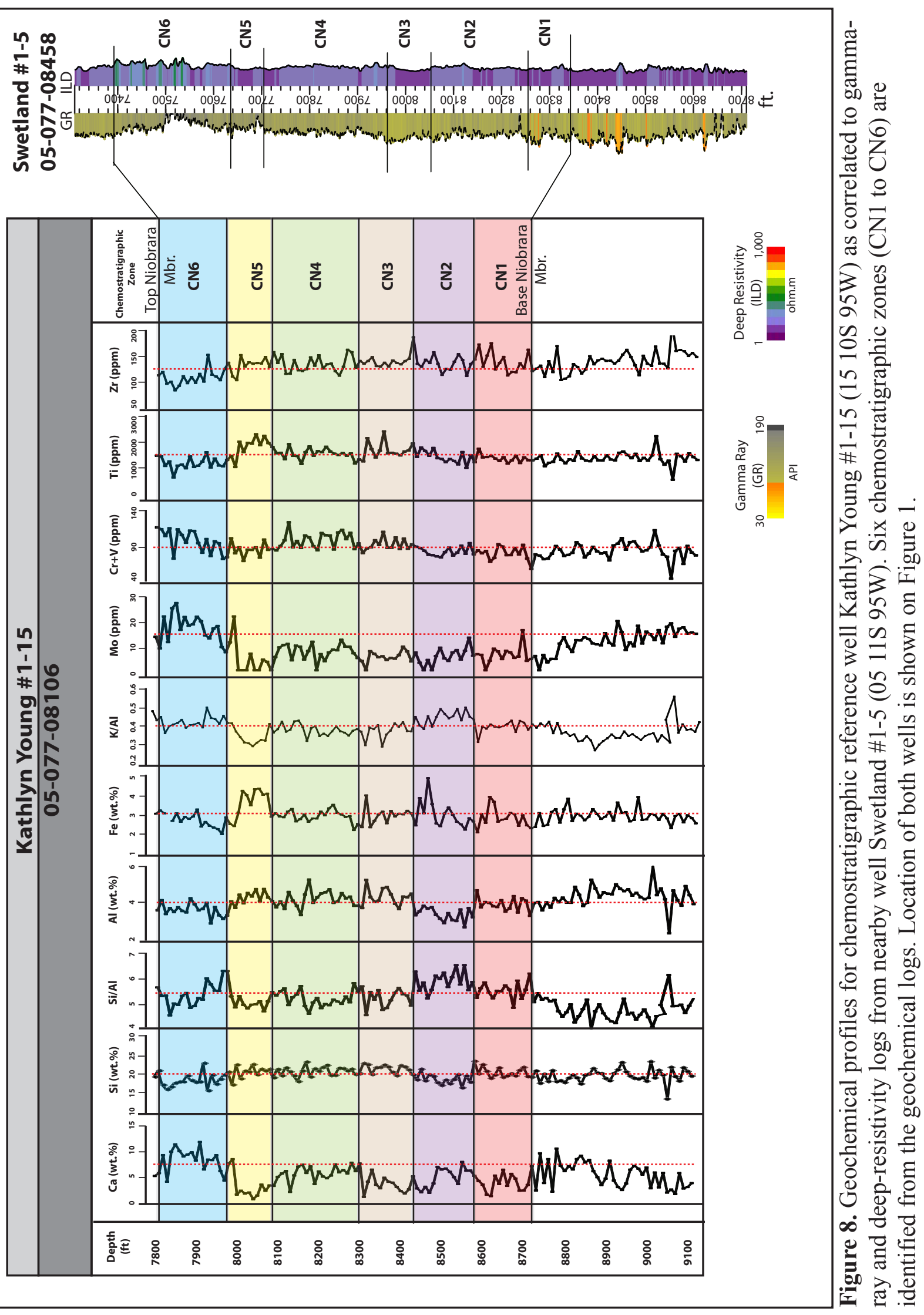


South Unit well. Values of Fe slightly decrease upward, whereas curves of Ti and Zr show an increase in the lower half of this zone followed by lower values. Within zones CN1 and CN2, values of Mo and $\mathrm{Cr}+\mathrm{V}$ are among the lowest across the Niobrara Member. The top of this zone is defined by lower $\mathrm{Si} / \mathrm{Al}, \mathrm{K} / \mathrm{Al}$, and Fe values, and higher $\mathrm{Al}$ values.

Chemostratigraphic Zone $\mathrm{CN} 3$ is characterized by lower $\mathrm{Ca}$ values. Si, Ti, Fe, and $\mathrm{Zr} \log$ curves show similar slightly upward-decreasing trends in five wells (Wht Face BT Fed, Deep White River Dome, Kathlyn Young, Baxter Pass South Unit, and Douglas A), and a constant trend in Barcus Creek Federal, Arco Deep, and O'Connell. Si/Al and K/Al curves show a slight decrease in most wells, with exceptions occurring within two wells (Wht Face BT Fed and Douglas A). Within this interval, $\mathrm{Mo}$ and $\mathrm{Cr}+\mathrm{V}$ curves display laterally persistent peaks of higher values. In most wells, the top of this zone is defined by an increase in $\mathrm{Ca}, \mathrm{Si}$, and $\mathrm{Al}$ values and a decrease in ratios $\mathrm{Si} / \mathrm{Al}$ and $\mathrm{K} / \mathrm{Al}$.

Chemostratigraphic Zone CN4 is the third calcium-enriched zone, with its base defined by a shift to higher $\mathrm{Ca}, \mathrm{Si} / \mathrm{Al}, \mathrm{Mo}$, and $\mathrm{Cr}+\mathrm{V}$ values. Overall, Ca values gradually increase upward, although local constant trends are noted (e.g., Kathlyn Young and Wht Face BT Fed). Curves of $\mathrm{Si} / \mathrm{Al}, \mathrm{K} / \mathrm{Al}, \mathrm{Mo}$, and $\mathrm{Cr}+\mathrm{V}$ show an upward-increasing trend, with exceptions occurring in the O'Connell, Deep White River Dome, and Barcus Creek Federal wells that show and upward decrease in $\mathrm{Cr}+\mathrm{V}$ values. $\mathrm{Al}$ and $\mathrm{Zr}$ values appear to decrease over this interval, whereas Fe and Ti curves show a uniform character. The top of this zone is characterized by an abrupt decrease in $\mathrm{Si} / \mathrm{Al}$ and $\mathrm{K} / \mathrm{Al}$ and an increase in $\mathrm{Fe}$ and $\mathrm{Al}$ values.

Chemostratigraphic Zone CN5 is one of the most geochemically distinctive zones within the study interval, displaying pronounced changes in log character. Overall, this interval has 
lower $\mathrm{Ca}$ values than the underlying zone. $\mathrm{Si}, \mathrm{Al}, \mathrm{Mo}, \mathrm{Cr}+\mathrm{V}$, and $\mathrm{Ti}$ values increase upward within most wells, whereas ratios $\mathrm{Si} / \mathrm{Al}$ and $\mathrm{K} / \mathrm{Al}$ decrease upward. $\mathrm{Zr}$ and Fe values show a slightly-increasing upward trend. The top of this zone is characterized by a shift to higher Si/Al and $\mathrm{K} / \mathrm{Al}$ values.

Chemostratigraphic Zone CN6 is the fourth calcium-enriched zone. CN6 is along with CN5, an easily-identifiable geochemical zone across the 9 wells, with its top (corresponding to the top of the Niobrara Member) defined by a marked decrease in Ca values. In general, Si/Al and $\mathrm{K} / \mathrm{Al}$ decrease upward, whereas $\mathrm{Al}$ and Fe values slightly increase upward in most wells. $\mathrm{Zr}$ and Ti values slightly decrease upward although some constant trends are noted locally. CN6 displays the highest Mo values recorded from the study interval, with Mo curves showing a slight decrease at the upper half of this zone.

\section{Chemostratigraphic Correlations}

The correlation of the six chemostratigraphic zones between wells was accomplished through the visual identification of significant trends. Although several compositional changes are consistent between the nine wells, many trends are not recognized within all wells, particularly when using lower-resolution datasets (e.g., $30 \mathrm{ft}$. [9.14 m] sampling interval). To the north, interwell correlations are more difficult and chemostratigraphic zones more poorly defined, with the geochemical differences between wells becoming more marked. Important geochemical differences that were recognized between wells are significant changes in $\mathrm{Ca}$ content: although four Ca-enriched zones are identified to the south and to the east of the study area, these defined cycles of Ca-enrichment are not laterally continuous features, suggesting that they are localized trends. Curves of $\mathrm{Si} / \mathrm{Al}$ and $\mathrm{K} / \mathrm{Al}$ appear to have the most laterally consistent trends and were the most useful in identifying correlative features over large distances. 
In siliciclastic sequences, the primary control on whole-rock geochemistry is lithology (Ratcliffe et al., 2007), and lateral changes of geochemical features can be attributed to (1) changes in detrital mineralogy and provenance composition, (2) changes in depositional environment and facies, and (3) diagenesis (Pearce et al., 2005).

Comparison of chemostratigraphic and lithostratigraphic correlations show that four "marker" horizons identified on the geochemical logs correspond to "marker" beds picked using gamma-ray and resistivity logs. The tops of chemostratigraphic zones $\mathrm{CN} 1, \mathrm{CN} 2, \mathrm{CN} 3$, and CN5

closely match the tops of lithostratigraphic units Niobrara 1, Niobrara 3, Niobrara 4, and Niobrara 6 respectively. Discrepancies involve the tops of chemostratigraphic zones CN2 and CN3 that were picked below the tops of Niobrara 3 and 4 within two wells (Baxter Pass South Unit and Douglas A wells; Appendix D), and top of CN5 that was picked above Niobrara 6 within White Face BT Fed well. These discrepancies may be accounted for by the low-resolution sampling intervals.

\section{Lateral Variation of Elements}

Average values of element concentrations and element ratios vary laterally for the six chemostratigraphic zones of the Niobrara Member. Limited data points toward the east-central portion of the basin make the constructed element contour maps less reliable over this area where no well control exists (Figures 9 to 12). Average Ca maps (Figure 9) indicate that $\mathrm{Ca}$ enrichment increased eastward, with the lowest values observed to the north and west. Chemostratigraphic zones $\mathrm{CN} 1$ and $\mathrm{CN} 4$ display the most dramatic lateral changes of average $\mathrm{Ca}$ concentrations whereas CN6 exhibits the highest degree of homogeneity of Ca enrichment. Similarly, average Mo maps (Figure 10) show a consistent gradual enrichment eastward, with chemostratigraphic zones $\mathrm{CN} 4, \mathrm{CN} 5$, and $\mathrm{CN} 6$ recording the highest Mo values. $\mathrm{Cr}+\mathrm{V}$ maps also show an eastward 


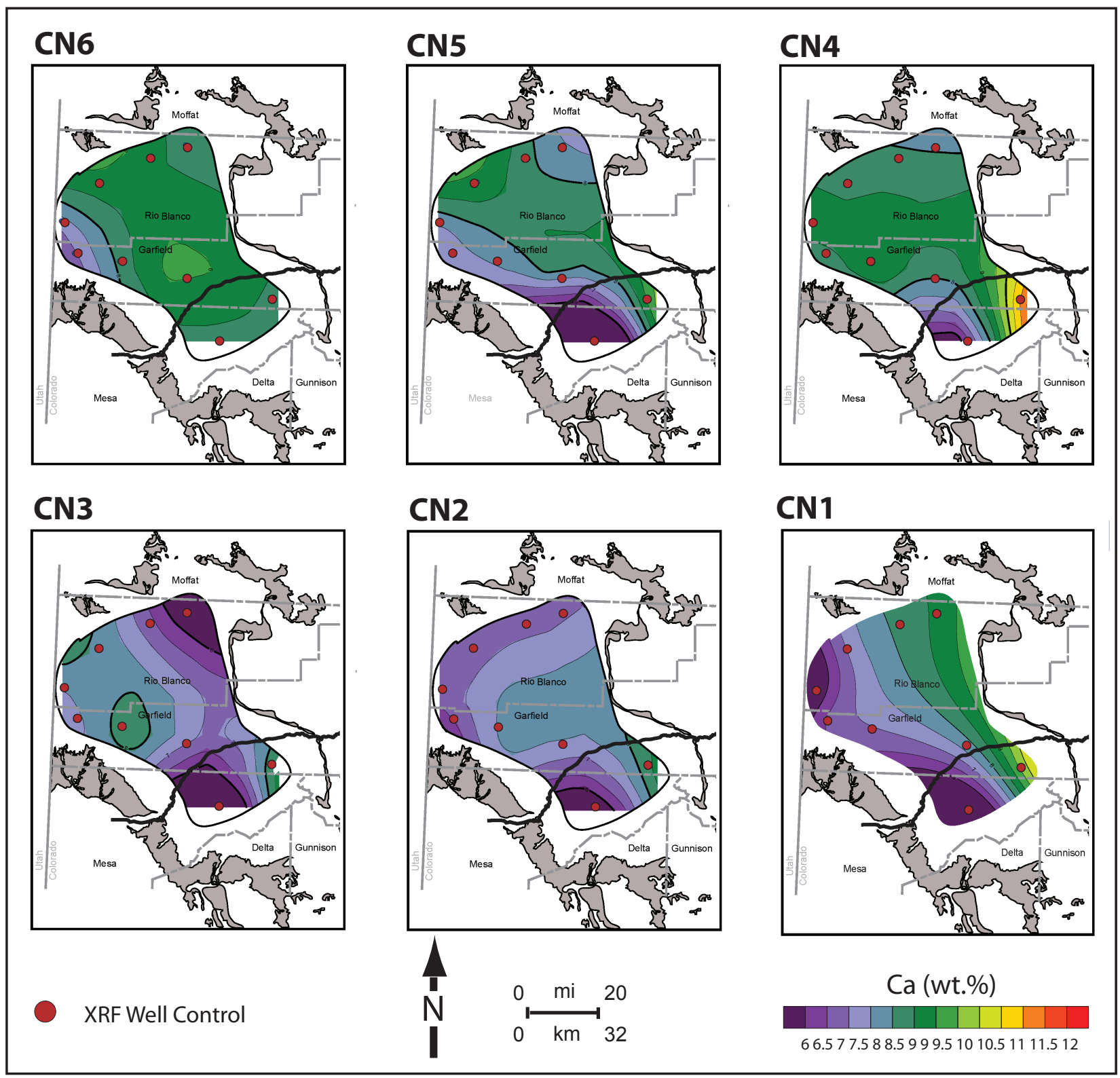

Figure 9. Average $\mathrm{Ca}$ (wt.\%) maps for the six chemostratigraphic zones of the Niobrara Member of the Mancos Shale. Stratigraphically upward, these zones are CN1 to CN6. Overall, Ca values increase to the east of the Piceance Basin. 


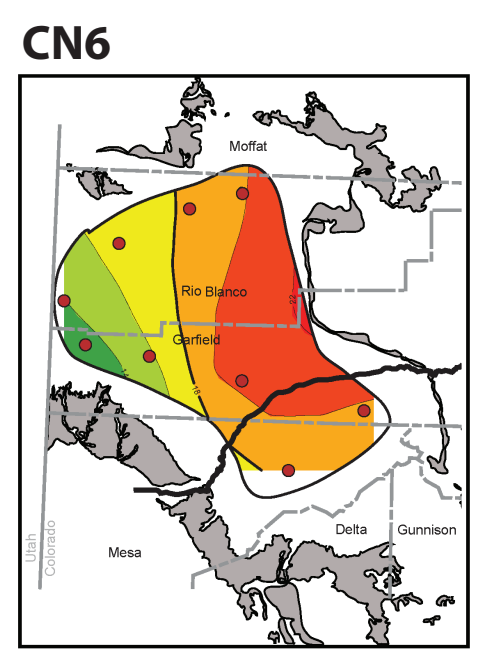

CN3

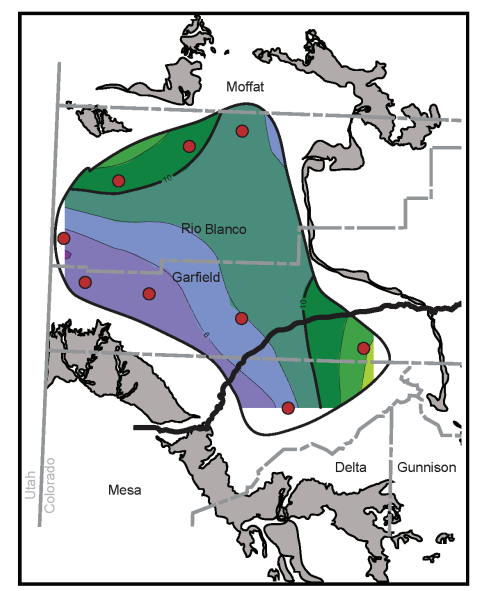

XRF Well Control

\section{CN5}

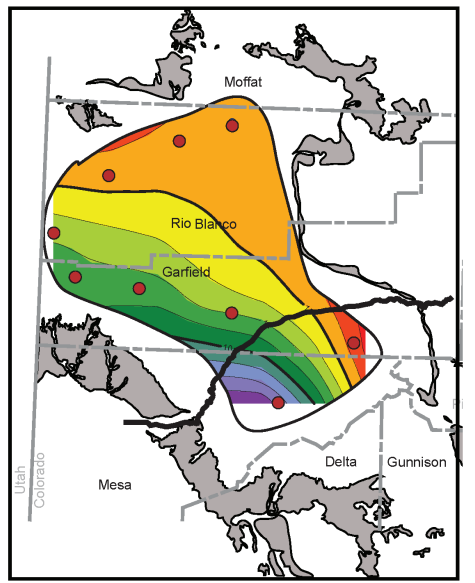

CN2

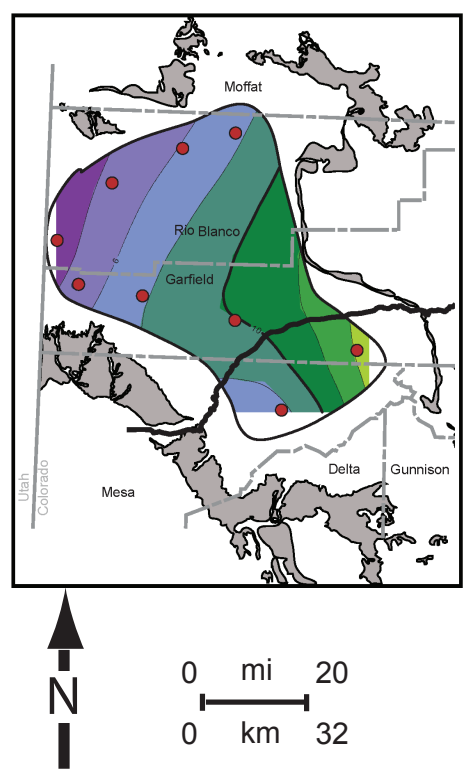

CN4

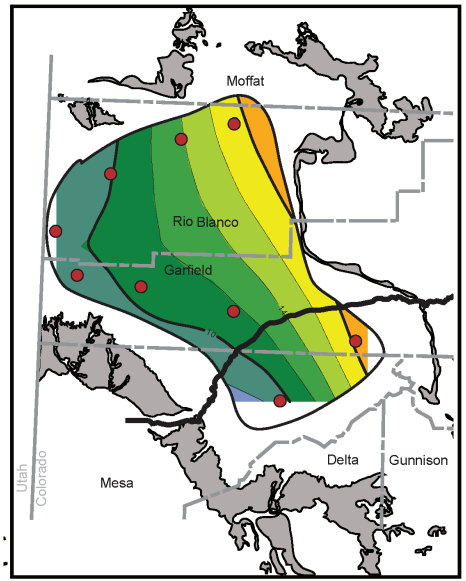

CN1

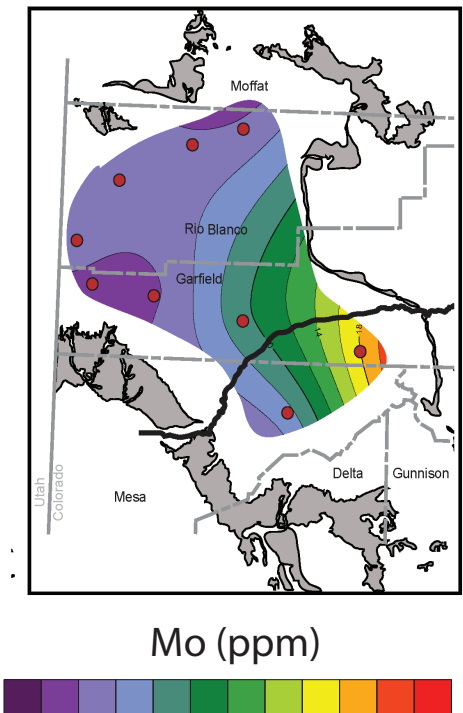

246810121416182022

Figure 10. Average Mo (ppm) maps for the six chemostratigraphic zones of the Niobrara Member of the Mancos Shale. Stratigraphically upward, these zones are CN1 to CN6. Overall, Mo values increase to the east of the Piceance Basin, suggesting that during deposition of the Niobrara Member, anoxia increased to the east. 
CN6

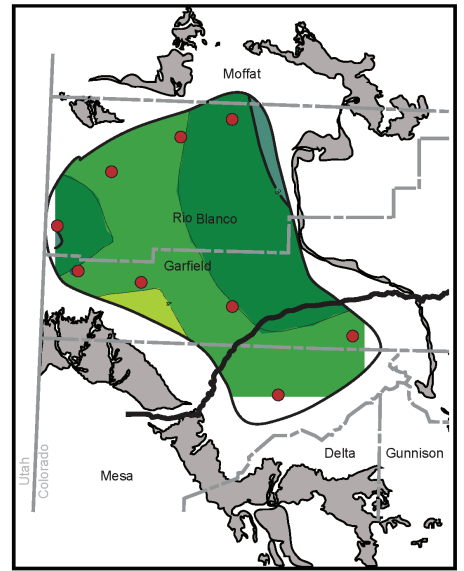

CN3

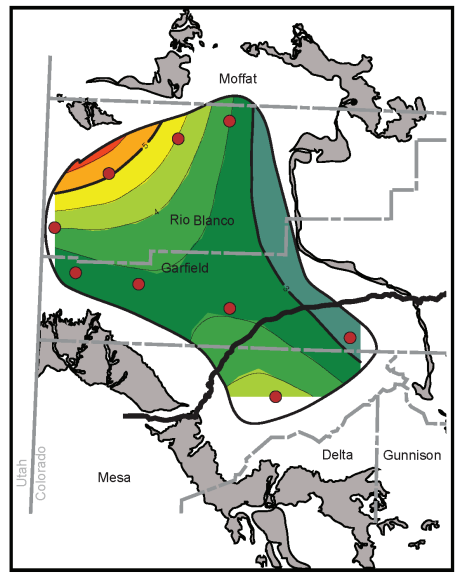

XRF Well Control

\section{CN5}

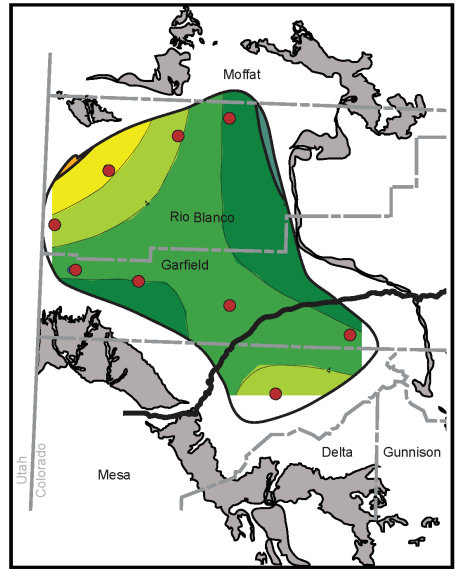

CN2
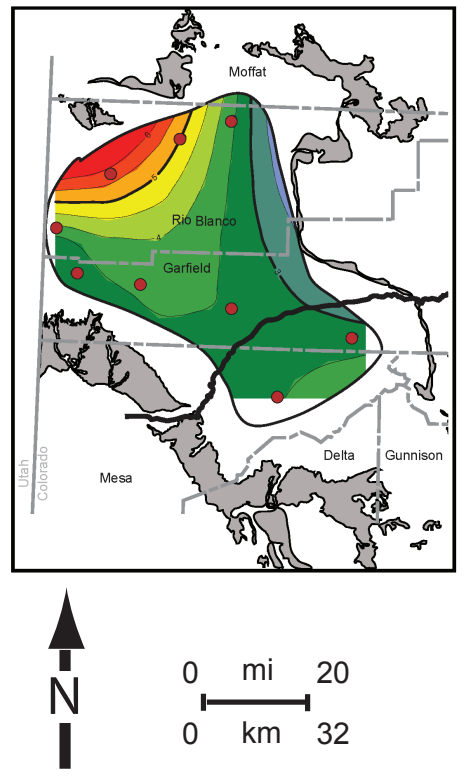

CN4

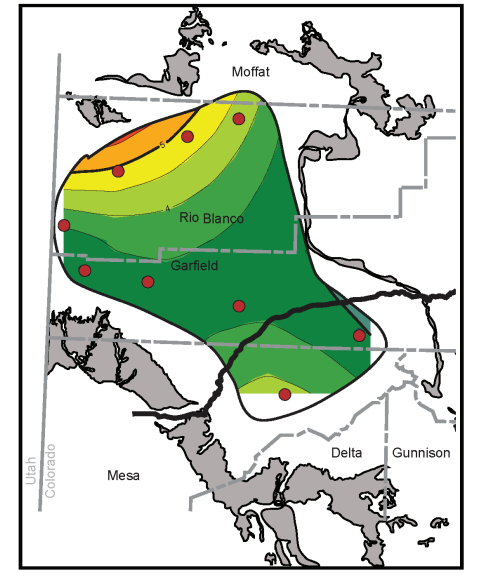

CN1

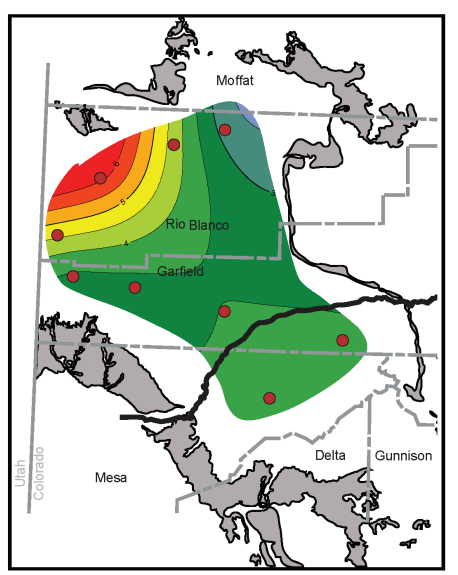

Al (wt.\%)

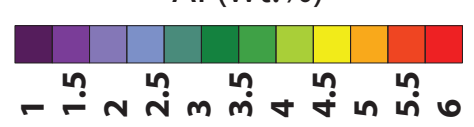

Figure 11. Average $\mathrm{Al}$ (wt.\%) maps for the six chemostratigraphic zones of the Niobrara Member of the Mancos Shale. Stratigraphically upward, these zones are CN1 to CN6. Overall, Al values increase to the northwest of the Piceance Basin, reflecting a closer proximity to the primary detrital source. 


\section{CN6}

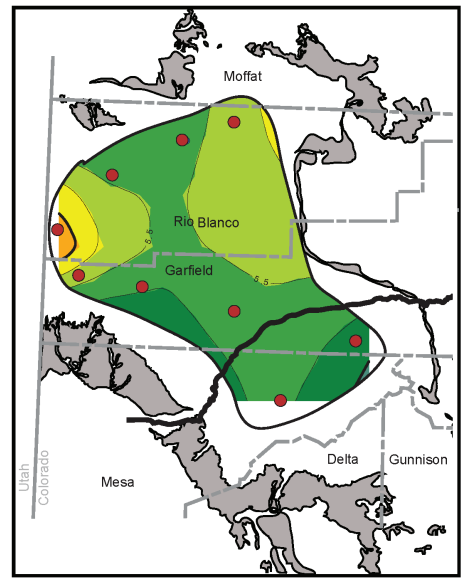

CN3

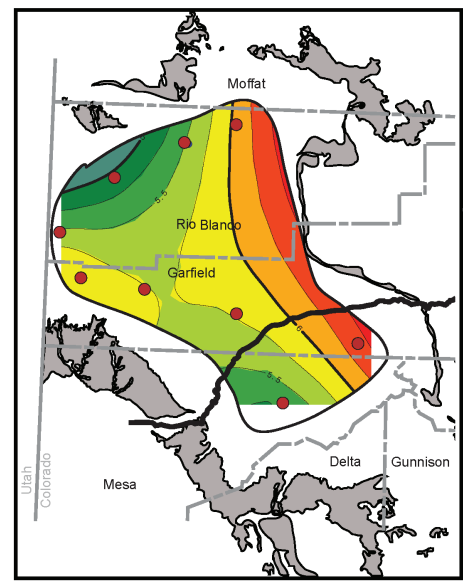

XRF Well Control
CN5

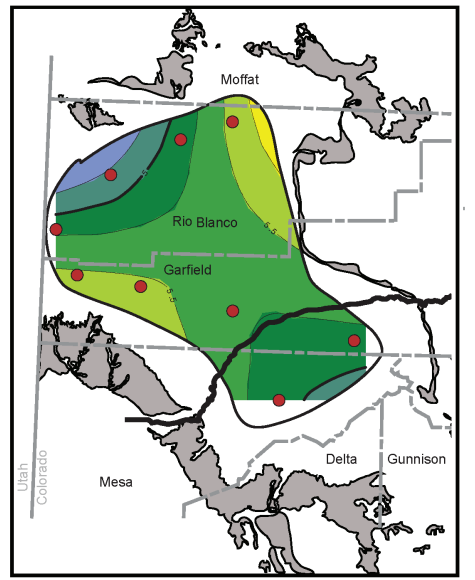

CN2
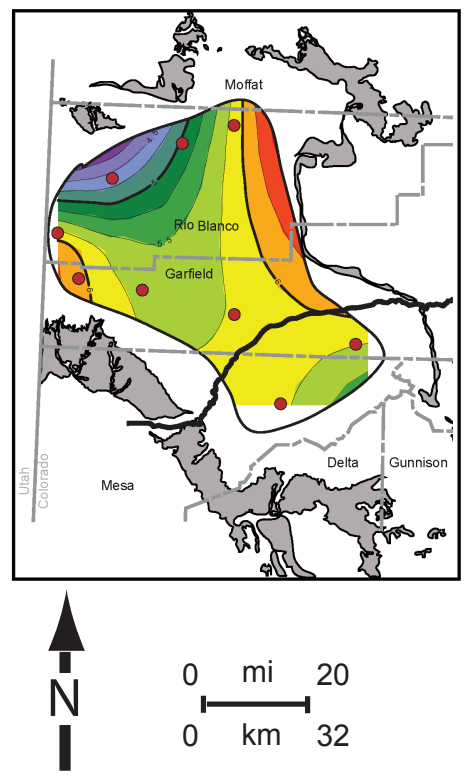

CN4

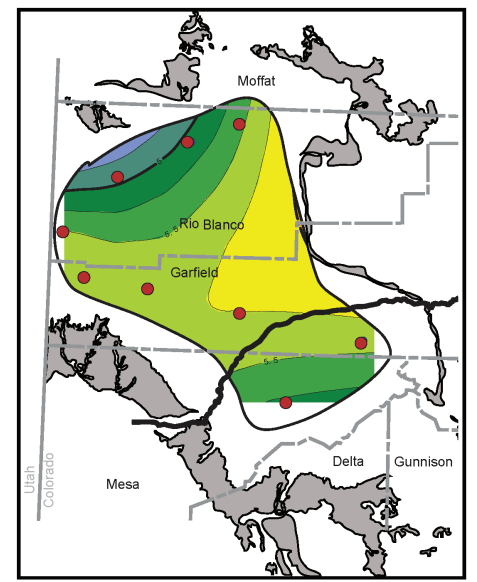

\section{CN1}

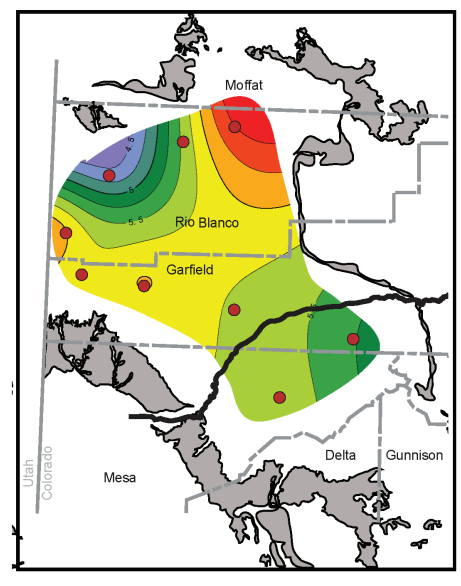

$\mathrm{Si} / \mathrm{Al}$

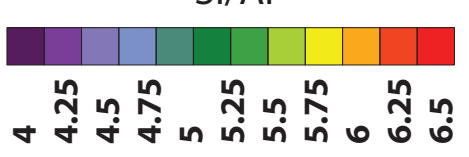

Figure 12. Average Si/Al maps for the six chemostratigraphic zones of the Niobrara Member of the Mancos Shale. Stratigraphically upward, these zones are CN1 to CN6. Overall, Si/Al values increase to the east of the Piceance Basin, demonstrating that the relative amount of quartz vs. clay increases to the east. 
trend (Appendix E). Average $\mathrm{Al}$ (Figure 11), $\mathrm{Si}$, and $\mathrm{Ti}+\mathrm{K}$ (Appendix E) maps display similar trends, with values of $\mathrm{Si}$ and $\mathrm{Ti}+\mathrm{K}$ significantly increasing to the northwest in all six chemostratigraphic zones. CN1 through CN4 exhibit the highest degree of Si enrichment, whereas $\mathrm{CN} 1$ through $\mathrm{CN} 5$ show the highest $\mathrm{Ti}+\mathrm{K}$ values. $\mathrm{Si} / \mathrm{Al}$ ratio maps (Figure 12) display an eastward-increasing trend, with the lowest values to the northwest, and moderate to high values westward. $\mathrm{K} / \mathrm{Al}$ maps (Appendix E) show a consistent trend within all six chemostratigraphic zones: average $\mathrm{K} / \mathrm{Al}$ ratio values increase to the northwest, with the most pronounced lateral variation exhibited within chemostratigraphic zone CN2.

\section{Controls on Element Distribution and Abundance}

Element ratios and element cross-plots highlight possible controls on element distribution and abundance, as well as element-mineral affinities (Pearce et al., 2005). In siliciclastic sediments, the $\mathrm{Si} / \mathrm{Al}$ ratio can be used as a proxy for the amount of quartz vs. Al-silicates (clays) (Ratcliffe et al., 2007). Laterally, the Si/Al ratio map (Figure 12) demonstrates that the relative amount of quartz vs. clay increases to the east within all chemostratigraphic zones. Peaks of $\mathrm{Si} / \mathrm{Al}$ on geochemical profiles suggest more silica input into the system from sources other than clays. Figure 8 indicates that the Niobrara Member comprises at least four intervals of increased $\mathrm{Si} / \mathrm{Al}$ (upper half of chemostratigraphic zone $\mathrm{CN} 1$, zone $\mathrm{CN} 2$, base of zone $\mathrm{CN} 4$, and zone CN6). To evaluate whether the excess silica in the Niobrara Member is of detrital or biogenic origin, cross-plots of Si with Al were used (Tribovillard et al., 2006). As shown in Figure 13, Si exhibits a linear relationship with $\mathrm{Al}$ suggesting that a large portion of the $\mathrm{Si}$ is detrital and resides within the clay fraction. This correlation increases consistently westward and northward, with the highest $\mathrm{R}^{2}$ recorded in the Barcus Creek Federal well $\left(\mathrm{R}^{2}=0.87\right)$. The lowest $\mathrm{R}^{2}$ values 


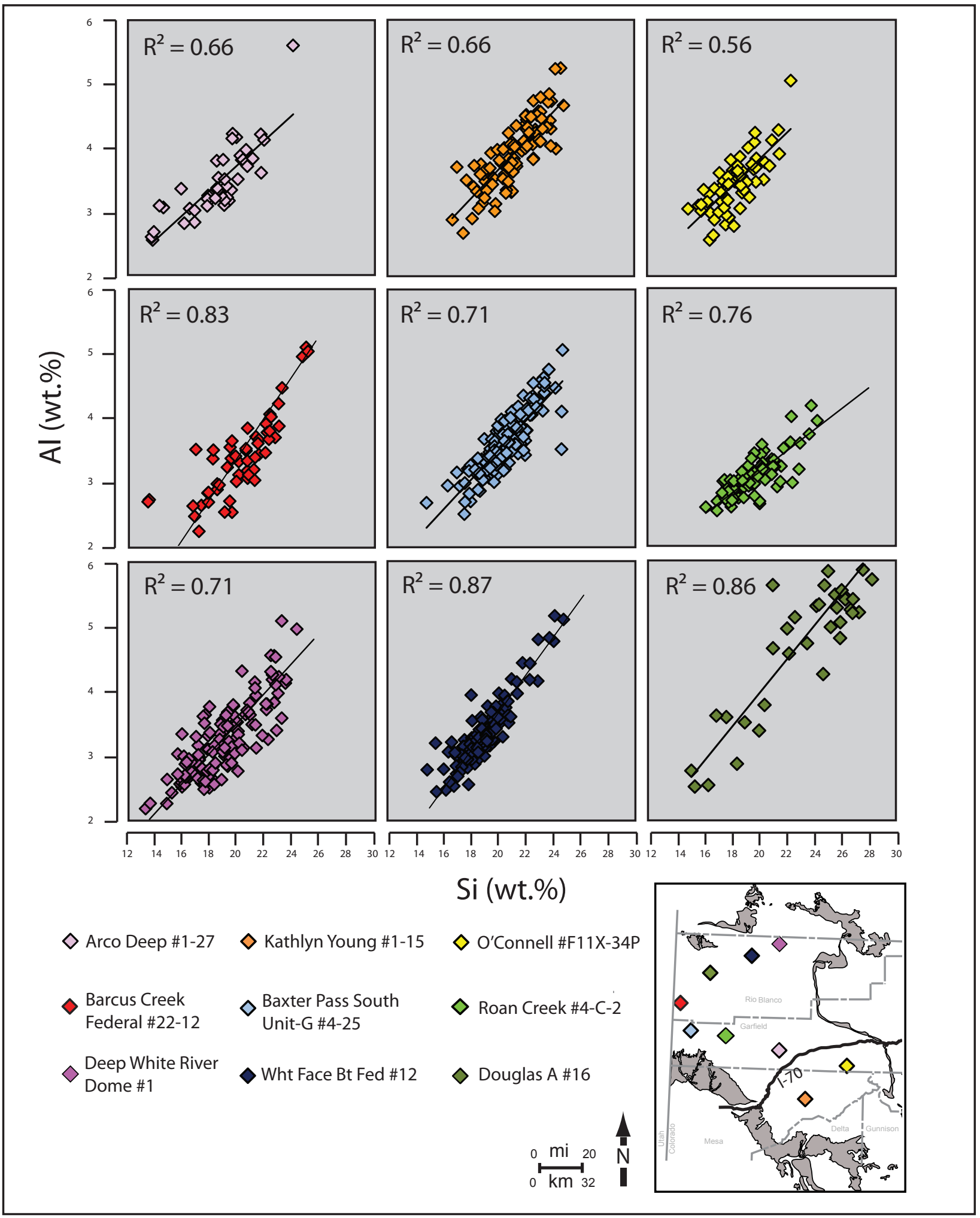

Figure 13. Variation of Al content (wt.\%) as a function of Si content (wt.\%) for all Niobrara Member samples within 9 wells. Al and Si show a moderate to strong linear relationship, suggesting that a large portion of the $\mathrm{Si}$ is detrital and resides witht the clay fraction. 
are observed in the eastern part of the basin $\left(\mathrm{O}^{\prime}\right.$ Connell well, $\left.\mathrm{R}^{2}=0.56\right)$, suggesting that in that area $\mathrm{Si}$ is more likely to be found in other compounds such as detrital or biogenic quartz.

Si exhibits a moderate to weak inverse correlation with $\mathrm{Ca}$ that is highest in the southeastern part of the basin $\left(\mathrm{R}^{2}=0.53\right)$ (Figure 14$) . \mathrm{R}^{2}$ values significantly and gradually decrease westward and northward, with the lowest value recorded in the White Face BT Fed well $\left(\mathrm{R}^{2}=\right.$ 0.05). This relationship suggests that in the Piceance Basin, the Niobrara Member is not a strictly bimodal carbonate and siliclastic system, but rather contains a mixture of clastic and carbonate deposits. Unlike descriptions of the Niobrara Member equivalent in the eastern and central parts of the Western Interior Seaway (e.g., in the Denver Basin) where informal subdivisions are based on varying proportions of carbonate and clastic minerals (Dean and Arthur, 1998), gradually decreasing $\mathrm{R}^{2}$ values indicate that the Niobrara Member becomes increasingly mixed to the west and to the north of the study area.

Levels of K/Al may indicate the relative abundance of the clay minerals illite/mica and kaolinite, as $\mathrm{K}$ is generally abundant in illite/mica and $\mathrm{Al}$ is abundant in kaolinite (Pearce et al., 2005). Increasing values of $\mathrm{K} / \mathrm{Al}$ thus reflect increasing illite/mica levels versus kaolinite.

Stratigraphically, higher K/Al values are recorded within Ca-enriched chemostratigraphic zones (CN1, CN2, CN4, and CN6) suggesting higher relative illite/mica versus kaolinite levels compared to other intervals (Figure 8; Appendix D). K/Al maps (Appendix E) show that higher relative illite/mica versus kaolinite levels are recorded to the northwest of the study area within all six chemostratigraphic zones.

\section{Interpretation of Changes in Paleoredox Conditions}

High organic-carbon concentrations are typically associated with sediments deposited in anoxic bottom-water conditions (Wright et al., 2010b). The use of elemental geochemistry in 


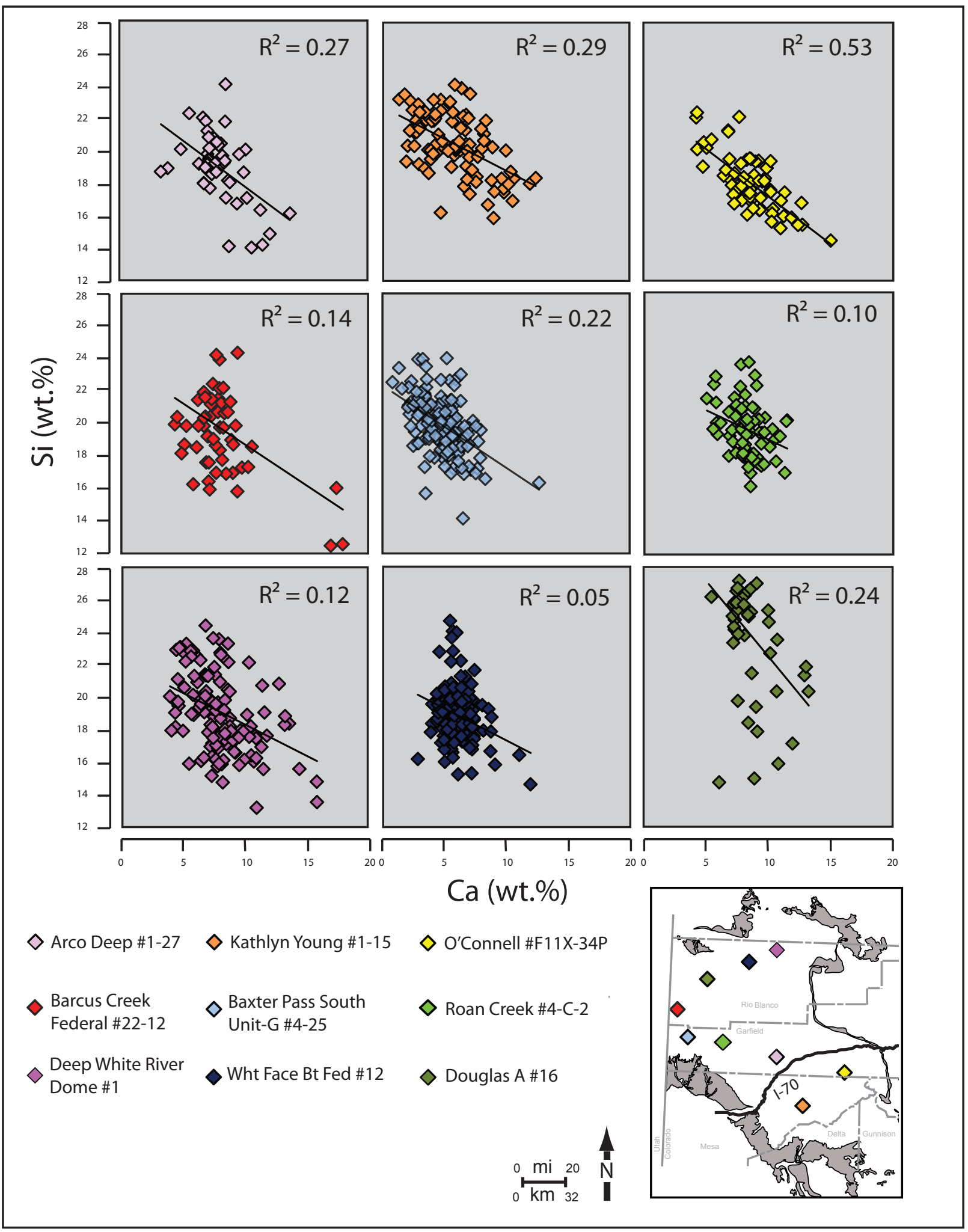

Figure 14. Variation of Si content (wt.\%) as a function of Ca content (wt.\%) for all Niobrara Member samples within 9 wells. $\mathrm{Ca}$ and $\mathrm{Si}$ show a moderate to weak inverse relationship. $\mathrm{R}^{2}$ values decrease to the west and to the north of the study area, suggesting that the Niobrara Member becomes an increasingly mixed more clastic than carbonate system. 
sediments as a proxy for paleoredox conditions is a well-documented application (e.g., Tribovillard et al., 2006; Turgeon and Brumsack; 2006, Tribovillard et al.; 2008; Jenkyns, 2010). Trace-metal concentrations and element ratios involving $\mathrm{Mo}, \mathrm{Cr}, \mathrm{V}, \mathrm{Ni}$, and $\mathrm{Zn}$ are geochemical proxies used as paleo-oxygenation indicators. This study uses variations in $\mathrm{Mo}, \mathrm{Cr}$, and $\mathrm{V}$ concentrations to identify zones deposited during low-oxygenation levels.

In sedimentary rocks, the presence of Mo is generally associated with authigenic enrichment under anoxic conditions. In oxic-water columns, Mo is highly stable in suspension and forms molybdate oxyanion $\left(\mathrm{MoO}_{2-4}\right)$, but adsorbs into humic substances, Mn-oxyhydroxides, or Fe-sulfides in anoxic environments (Berrang and Grill, 1974; Magyar et al., 1993; Morse and Luther III, 1999; Algeo and Lyons, 2006). Under reducing conditions, Cr substitutes for Al within clays, and V bonds with organic matter (Jones and Manning, 1994; Rimmer, 2004; Mackenzie, 2005). Therefore, an increase in the sum $\mathrm{Cr}+\mathrm{V}$ marks a reduction in the availability of oxygen in the system (Mackenzie, 2005).

Stratigraphic (depth) profiles of Mo and $\mathrm{Cr}+\mathrm{V}$ suggest that more anoxic conditions existed during deposition of the upper zones (CN4, CN5, and CN6), whereas higher oxygenation levels were present during deposition of the stratigraphically lower zones (CN1 through CN3) (Figure 8; Appendix D). Average Mo and $\mathrm{Cr}+\mathrm{V}$ maps show that during deposition of the Niobrara Member, anoxia increased to the east (Figure 10; Appendix E). Authigenic enrichment of $\mathrm{V}$ is further supported by cross-plots of Al vs. V that do not show linear trends (Appendix F).

\section{Interpretation of Changes in Terrestrial Input}

In addition to bottom-water redox conditions, terrestrial input controls the amount of organic matter preserved in shales (Tribovillard et al., 2006, Turgen and Brumsack, 2006, 
Tribovillard et al., 2008, Negri et al., 2009, Jenkyns, 2010), and changes in terrestrial input can be interpreted from major and trace-element data.

$\mathrm{Al}$ is a detrital element commonly used as a proxy for clay because it is scarce in seawater and is generally not affected by biologic or diagenetic processes (Orians and Bruland, 1986, Brumasck, 2006). Similarly, Ti and Zr have very low seawater concentrations and are not involved in biologic cycling ( $\mathrm{Li}, 1982)$, with Ti being usually associated with Ti oxides, and $\mathrm{Zr}$ with zircon. Therefore, peaks of $\mathrm{Al}, \mathrm{Ti}$, and $\mathrm{Zr}$ on geochemical logs indicate detrital input into the system (Piper and Calvert, 2009).

Stratigraphically, two to three pulses of increased terrestrial input within the Niobrara Member are identified (Figure 8): CN1 transitioning to CN2, CN3 (locally), and CN4 transitioning to CN5. Laterally, the highest level of detrital elements is recorded to the northwest of the study area, reflecting a closer proximity to the detrital source (Figure 11; Appendix D).

Geochemical plots of $\mathrm{Ca}, \mathrm{Al}, \mathrm{Ti}$, and $\mathrm{Zr}$ show that the chemostratigraphic zonation of the Niobrara Member corresponds with shifts in depositional systems (Figure 8). Chemostratigraphic zones $\mathrm{CN} 1$ and $\mathrm{CN} 2$ contain higher $\mathrm{Ca}$ content than the overlying zone $\mathrm{CN} 3$, and within these zones, where $\mathrm{Ca}$ values appear to decrease, terrestrial input can be seen to increase. The base of chemostratigraphic zone $\mathrm{CN} 3$ marks a shift from a carbonate depositional system to a siliciclastic depositional system. Terrestrial input increases through chemostratigraphic zone $\mathrm{CN} 3$, before shifting to lower values at the base of the Ca-enriched chemostratigraphic zone CN4 (carbonate depositional system). Within chemostratigraphic zone $\mathrm{CN} 5$, terrestrial input is seen to increase again, reflecting a second shift to a siliclastic depositional system, and coinciding with a lower $\mathrm{Ca}$ content. The base of chemostratigraphic zone CN6 marks a shift to a carbonate depositional system with $\mathrm{Al}, \mathrm{Ti}$, and $\mathrm{Zr}$ shifting to lower values and slightly decreasing upward. 
Moreover, comparison of $\mathrm{Al}, \mathrm{Ti}$, and $\mathrm{Zr}$ with Mo logs suggests that when terrestrial input was highest, bottom-water conditions were at their least reducing.

\section{STRATIGRAPHIC AND GEOGRAPHIC DISTRIBUTION OF ORGANIC MATTER}

\section{Thermal Maturity}

This study uses average vitrinite reflectance (\%Ro) data converted to LOM for TOC calculations. \%Ro data were selected instead of Tmax because they are typically more representative of thermal maturity, particularly in highly mature samples (D. Thul, 2013, personal communication).

LOM changes within the Niobrara Member in the study area are depicted in Figure 15. Contours of LOM indicate that maturation of the Niobrara Member exceeds values of 7.5 LOM (corresponding to $0.5 \%$ Ro) over much of the Piceance Basin. Thermal maturity increases to the northeast attaining the highest values ( $\mathrm{LOM}=11$, corresponding to $1.2 \% \mathrm{Ro}$ ) within the center of the Piceance Basin, suggesting that the Niobrara Member (Lower Mancos Shale) has passed through the oil window and is presently within the gas generation window (Kirschbaum, 2003).

\section{Organic Richness}

Two cross sections (CC' and DD') using TOC profiles produced from applying the $\Delta$ Log R technique are presented in Figure 16. Two important features of the $\Delta \log \mathrm{R}$-derived TOC profiles for the Niobrara Member interval are (1) the vertical variation in TOC and (2) the apparent similarity in vertical TOC distribution among the investigated wells. Three main intervals of higher TOC values are identified: chemostratigraphic zone CN6, chemostratigraphic zone $\mathrm{CN} 5$, and the lower third of chemostratigraphic zone CN2. Estimated TOC values are 


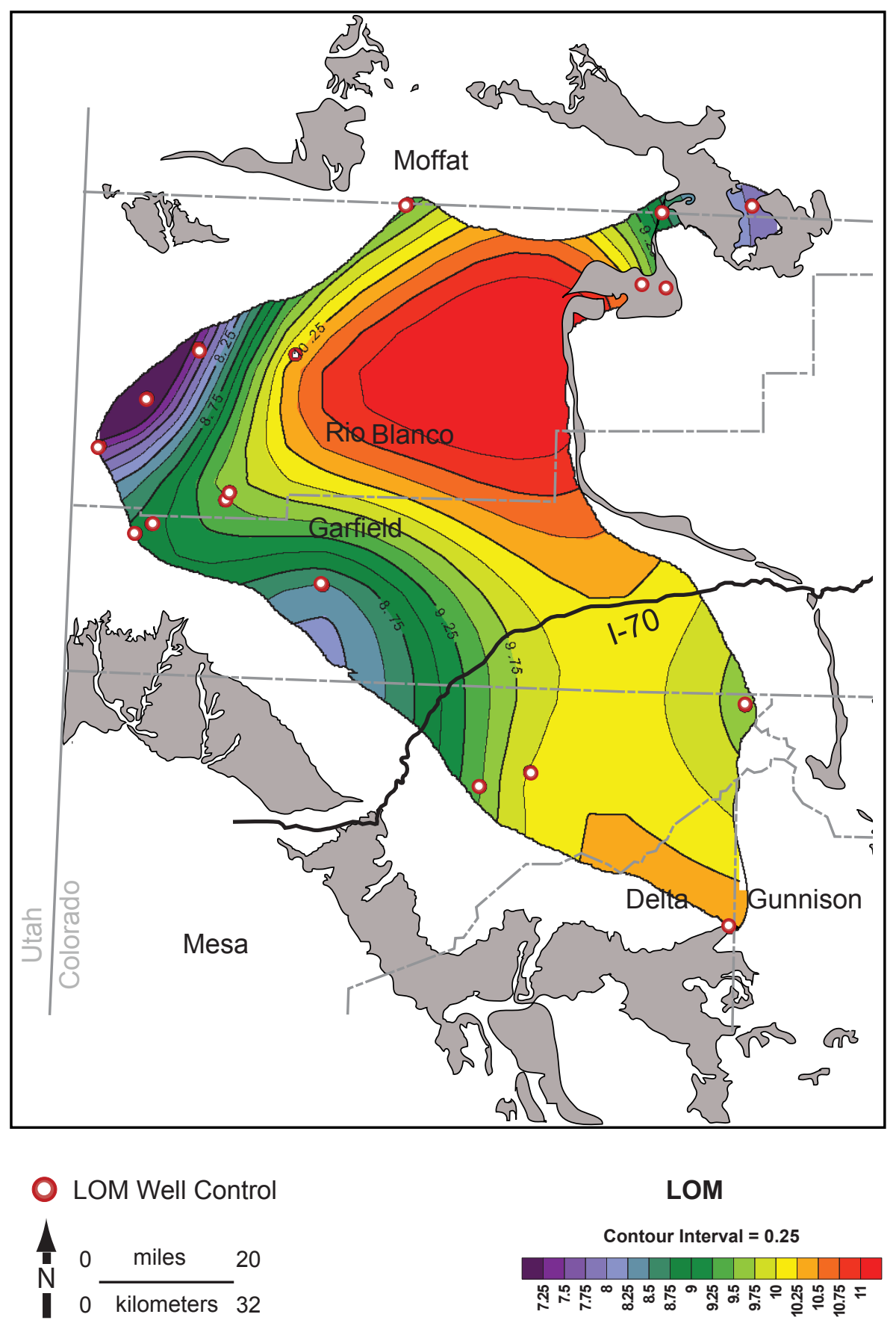

Figure 15. Contour map of level of organic metamorphism (LOM) for the Niobrara Member of the Mancos Shale. LOM values for control wells obtained using vitrinite reflectance data (from USGS Core Library data files) converted to LOM using the formula of LeCompte and Hursan (2010). Thermal maturity of the Niobrara Member increases toward the center of the Piceance Basin. 


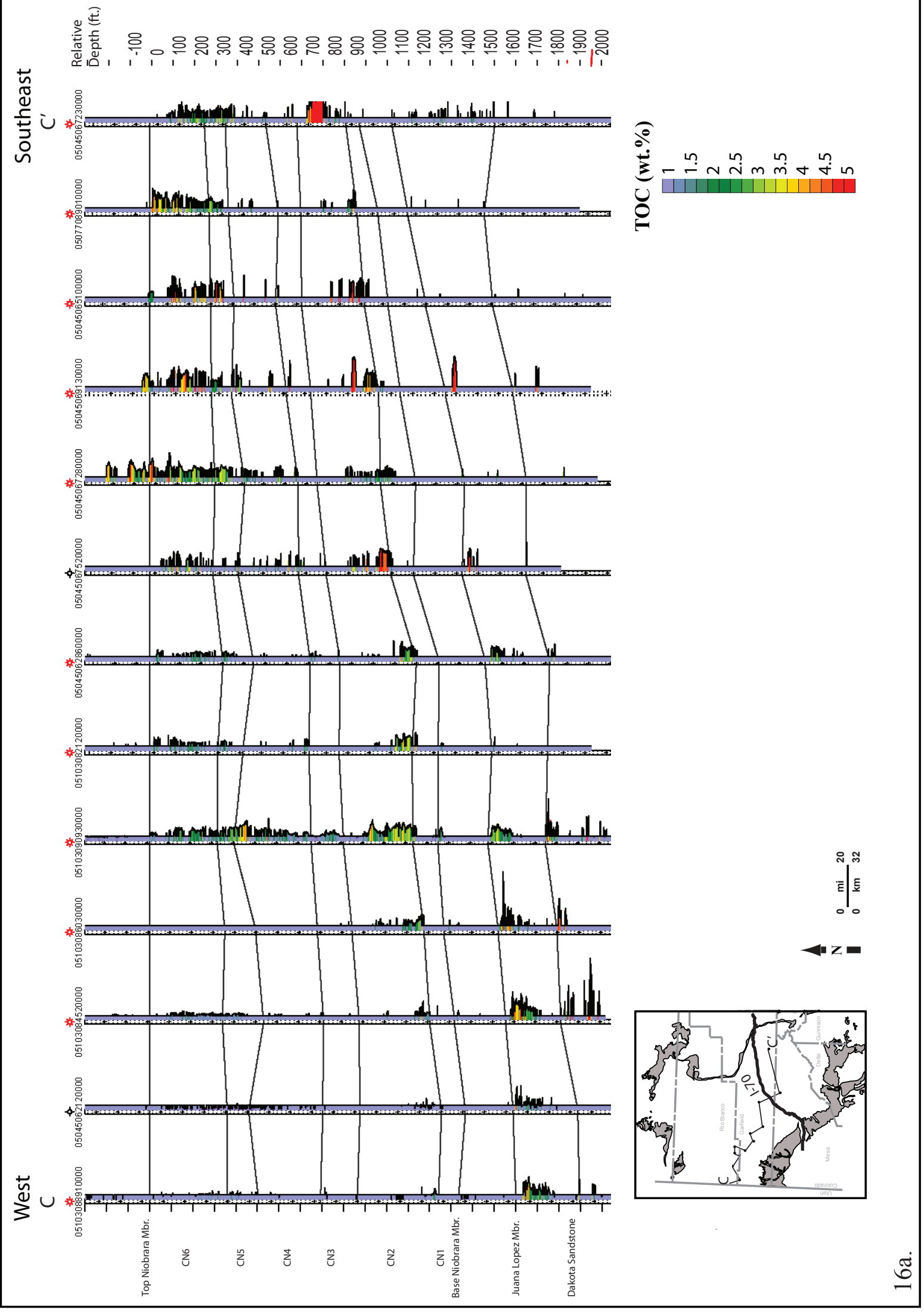




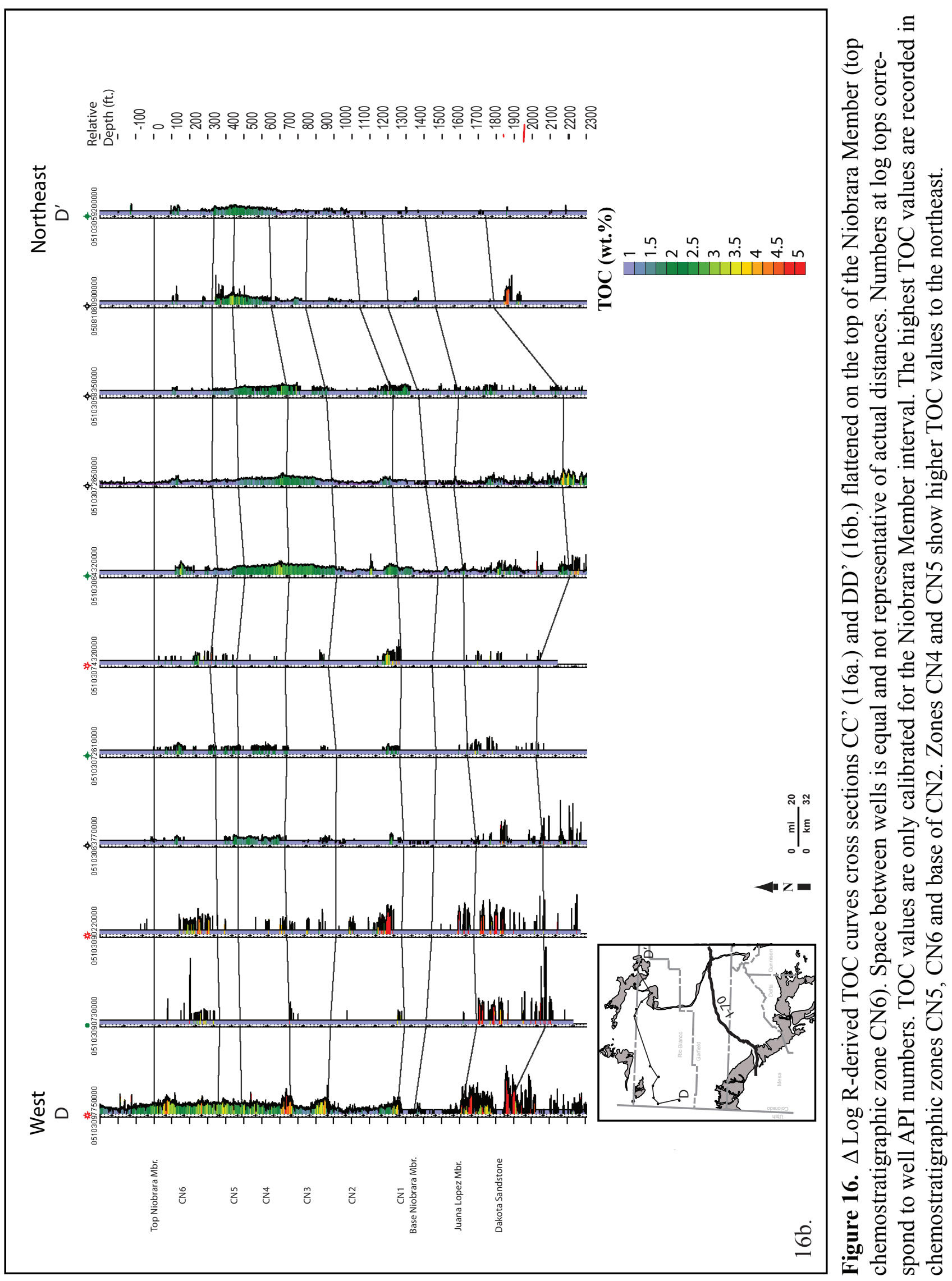


relatively low through most of chemostratigraphic zones $\mathrm{CN} 1, \mathrm{CN} 3$, and $\mathrm{CN} 4$. The highest average TOC value is recorded in Mesa County within chemostratigraphic zone CN6 (2.37 wt.\%), whereas the lowest (1 wt.\%) is recorded in both Moffat and Mesa counties (chemostratigraphic zones $\mathrm{CN} 2$ and $\mathrm{CN} 3$ respectively) (Table 2). For the entire study area, the highest average TOC value is recorded within chemostratigraphic zone CN6 (1.46 wt.\%), and the lowest within chemostratigraphic zone CN1 (1.08 wt.\%). Cross section DD' (Figure 16) shows that chemostratigraphic zones $\mathrm{CN} 4$ and $\mathrm{CN} 5$ exhibit locally high TOC values to the north and to the northeast of the study area.

Average $\Delta \log$ R-derived TOC maps for the six chemostratigraphic zones of the Niobrara Member (Figure 17) show that TOC values generally increase from 1 to $3 \mathrm{wt} . \%$ to the south and to the east within chemostratigraphic zones $\mathrm{CN} 2, \mathrm{CN} 5$, and $\mathrm{CN} 6$. Zones $\mathrm{CN} 4$ and $\mathrm{CN} 5$ also display a local increase to the northeast, whereas zones $\mathrm{CN} 1$ and $\mathrm{CN} 3$ show relatively lower values across the basin.

Areas recording anoxic bottom-water conditions appear to correspond to areas of higher TOC values. Chemostratigraphic zones $\mathrm{CN} 4$ and $\mathrm{CN} 5$ display relatively higher TOC values to the northeast of the basin (Figure 16). This area also exhibits higher Mo levels (Figure 10). Mo maps also suggest relatively less anoxic conditions within chemostratigraphic zones CN1 through $\mathrm{CN} 3$, which appear to correspond to lower overall TOC values in these zones compared to $\mathrm{CN} 5$ and $\mathrm{CN} 6$.

\section{Calibration and Accuracy of TOC Calculations}

The mean absolute error (MAE; measured in wt.\%) is provided to show how close the $\Delta$ Log R-derived TOC values are to measured TOC values from cutting samples. Wells of higher 


\begin{tabular}{|c|c|c|c|c|c|}
\hline $\begin{array}{l}\text { Chemostratigraphic } \\
\text { Zone }\end{array}$ & $\mathbf{N}$ & $\begin{array}{l}\text { Min TOC } \\
\text { (wt.\%) }\end{array}$ & $\begin{array}{c}\text { Mean TOC } \\
\text { (wt.\%) }\end{array}$ & $\begin{array}{l}\text { Max TOC } \\
\text { (wt.\%) }\end{array}$ & $\begin{array}{l}\text { Std TOC } \\
\text { (wt.\%) }\end{array}$ \\
\hline Garfield County & 16 & & & & \\
\hline CN6 & & 1.00 & 1.92 & 4.90 & 1.04 \\
\hline CN5 & & 1.00 & 1.42 & 3.86 & 0.73 \\
\hline CN4 & & 1.00 & 1.16 & 3.41 & 0.45 \\
\hline CN3 & & 1.00 & 1.05 & 2.66 & 0.22 \\
\hline CN2 & & 1.00 & 1.56 & 4.94 & 1.03 \\
\hline CN1 & & 1.00 & 1.22 & 4.18 & 0.53 \\
\hline Mesa County & 1 & & & & \\
\hline CN6 & & 1.00 & 2.37 & 4.77 & 1.14 \\
\hline CN5 & & 1.00 & 1.38 & 3.14 & 0.63 \\
\hline CN4 & & 1.00 & 1.10 & 3.11 & 0.40 \\
\hline CN3 & & 1.00 & 1.00 & 1.00 & 0.00 \\
\hline CN2 & & 1.00 & 1.19 & 2.82 & 0.50 \\
\hline CN1 & & 1.00 & 1.10 & 5.12 & 0.56 \\
\hline Moffat County & 1 & & & & \\
\hline CN6 & & 1.00 & 1.32 & 8.05 & 0.70 \\
\hline CN5 & & 1.00 & 2.33 & 5.07 & 0.53 \\
\hline CN4 & & 1.00 & 1.27 & 2.31 & 0.39 \\
\hline CN3 & & 1.00 & 1.09 & 1.90 & 0.20 \\
\hline CN2 & & 1.00 & 1.00 & 1.34 & 0.05 \\
\hline CN1 & & 1.00 & 1.03 & 3.72 & 0.20 \\
\hline Rio Blanco County & 50 & & & & \\
\hline CN6 & & 1.00 & 1.27 & 3.29 & 0.38 \\
\hline CN5 & & 1.00 & 1.40 & 2.94 & 0.34 \\
\hline CN4 & & 1.00 & 1.37 & 3.44 & 0.38 \\
\hline CN3 & & 1.00 & 1.11 & 2.85 & 0.27 \\
\hline CN2 & & 1.00 & 1.40 & 2.94 & 0.34 \\
\hline CN1 & & 1.00 & 1.04 & 3.64 & 0.26 \\
\hline All counties & 68 & & & & \\
\hline CN6 & & 1.00 & 1.46 & 3.76 & 0.55 \\
\hline CN5 & & 1.00 & 1.43 & 3.19 & 0.44 \\
\hline CN4 & & 1.00 & 1.31 & 3.41 & 0.40 \\
\hline CN3 & & 1.00 & 1.1 & 2.76 & 0.26 \\
\hline CN2 & & 1.00 & 1.27 & 4.10 & 0.59 \\
\hline CN1 & & 1.00 & 1.08 & 3.79 & 0.33 \\
\hline
\end{tabular}

$\mathrm{N}=$ Number of Wells; Min = Minimum; Max = Maximum; Std = Standard Deviation

Table 2. Statistical summary of $\Delta$ Log R-derived TOC for each chemostratigraphic zone (CN1 to CN6) of the Niobrara Member of the Mancos Shale. The minimum calculated TOC value is constant ( $=1 \mathrm{wt} . \%$ TOC) because baselining the transit-time and resistivity curves considers the baselined interval as "zero TOC" and therefore background TOC (of 1 wt.\%) was added back to the calculated value. 
CN6

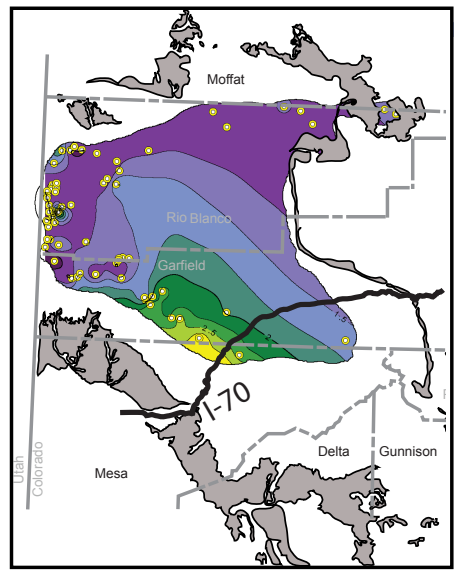

\section{CN3}

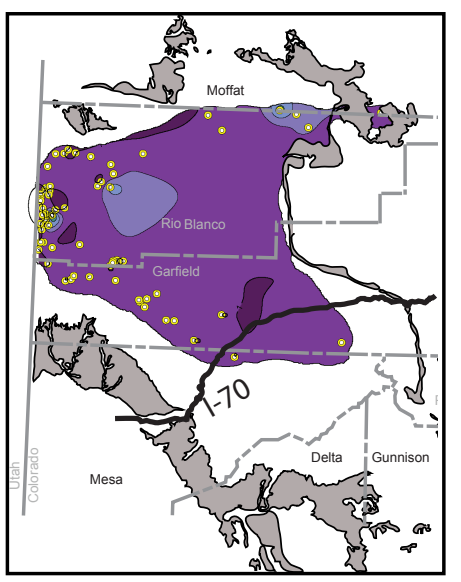

CN5

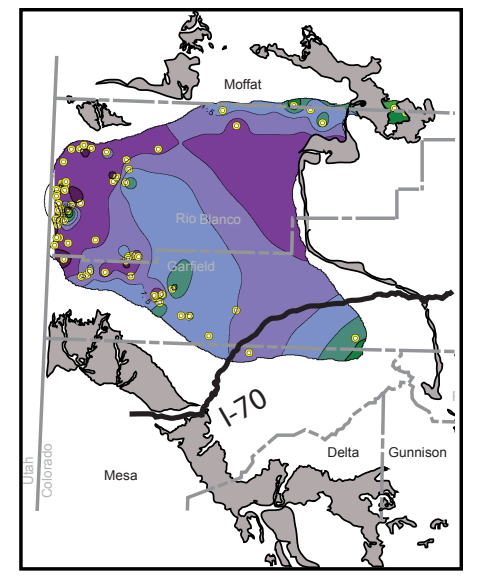

CN2
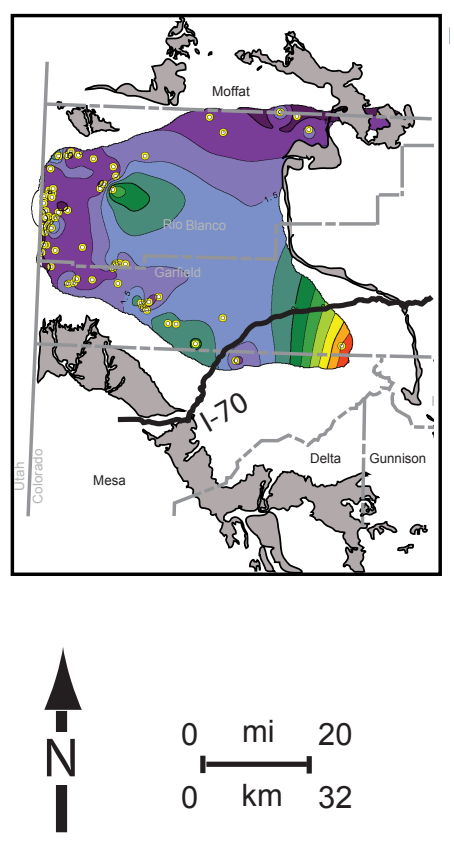

CN4

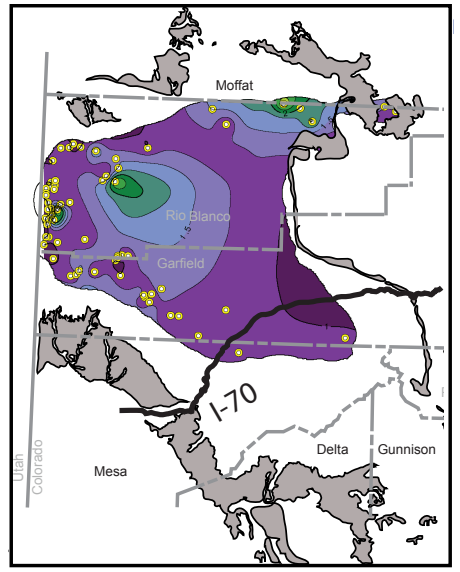

CN1

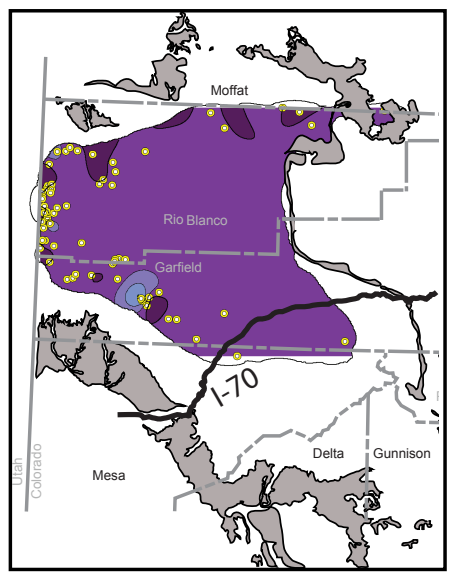

TOC (wt.\%)

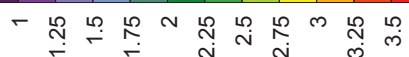

Figure 17. Average $\Delta$ Log R-derived TOC maps for the six chemostratigraphic zones of the Niobrara Member of the Mancos Shale. Stratigraphically upward, these zones are CN1 to CN6. Yellow discs on maps are well control locations. Chemostratigraphic zones CN2, CN5, and CN6 show increasing TOC values to the southern and eastern portions of the basin, whereas zones $\mathrm{CN} 4$ and $\mathrm{CN} 5$ show a local increase to the northeast. 
maturity $(\mathrm{LOM}=8.92$ and $\mathrm{LOM}=9.36)$ exhibit lower MAE (and thus higher accuracy) compared to wells of lower maturity $(\mathrm{LOM}<8)($ Table 3$)$.

As detailed in Passey et al. (1990), anomalous sonic or resistivity log responses not associated with source intervals may result in inaccurate TOC calculations. Although a qualitative method was used to remove potentially anomalous TOC values (associated with anomalous sonic or resistivity values) from the analysis (Appendix B), this method may underestimate TOC over some organic-rich intervals, because only background TOC $(1 \mathrm{wt} . \%)$ is accounted for.

The estimation of the maturity parameter (LOM) is another factor potentially contributing to the discrepancy between measured and log-derived TOC values. Although LOM values were obtained from the conversion of vitrinite reflectance data in 18 wells, a margin of error may be present when estimating LOM within other wells. However, if the value of LOM is not properly estimated, "absolute TOC values will be somewhat in error, but the vertical variability in TOC will be correctly represented" (Passey et al., 1990, p. 1779).

In addition, because little is known about the cuttings data (e.g., hole quality, possible high-grading), uncertainty may arise regarding the quality of the comparison between cuttingsand $\Delta \log \mathrm{R}$-derived data.

\section{Qualitative Interpretation of Relative Rock Brittleness}

Production from shale-gas reservoirs typically require fracture stimulation and wells are typically drilled horizontally in the most brittle rock. Brittle rocks are generally silica and/or carbonate enriched, whereas ductile rocks are considered to be clay-mineral and organic (TOC) rich (Slatt and Abousleiman, 2011). 


\begin{tabular}{lcccc}
\hline Well Name/No & API\# & LOM & N & MAE (wt.\%) \\
\hline Taiga Mtn \#6-22 & 05103089200000 & 7.38 & 18 & 0.53 \\
Baxter Pass South Unit - G\#4-25 & 05045051060000 & 7.66 & 6 & 0.51 \\
Federal \#9-25-1-2 & 05103084610000 & 7.99 & 2 & 0.65 \\
Lynch Creek-Gov \#1 & 05081060900000 & 8.00 & 4 & 0.62 \\
South Baxter Pass Unit \#2-20 & 05045051120000 & 8.92 & 32 & 0.40 \\
Arco Deep \#1-27 & 05045065100000 & 9.36 & 9 & 0.25 \\
\hline
\end{tabular}

with MAE $=\frac{1}{N} \sum_{i=1}^{N} \mid$ FinalTOC - TOCm $\mid$

$\mathrm{N}=$ number of samples analyzed; FinalTOC $=\Delta$ Log R-derived TOC; TOCm $=$ measured TOC values from cuttings data

Table 3. Accuracy of $\Delta$ Log R-derived TOC in terms of mean absolute error (MAE) between cuttings TOC data (from USGS Core Library files) and $\Delta$ Log R-derived TOC values in 6 wells. 
As previously discussed, chemostratigraphic zones $\mathrm{CN} 1, \mathrm{CN} 2, \mathrm{CN} 4$, and $\mathrm{CN} 6$ are Caenriched and are associated with a relatively high quartz/clay ratio (with $\mathrm{CN} 1, \mathrm{CN} 2$, and CN4 being TOC poor). These zones can be interpreted to be relatively brittle. Chemostratigraphic zone $\mathrm{CN} 5$ (organic-rich) and $\mathrm{CN} 3$ have lower $\mathrm{Ca}$ and $\mathrm{Si} / \mathrm{Al}$ values and higher $\mathrm{Al}$ values. These zones can be interpreted to be more ductile. These interpretations suggest that within the Niobrara Member, rocks occur as alternating brittle and ductile intervals. Brittle intervals are suggested to be better targets for horizontal wells, as they are considered better stimulated by artificial fracturing and appear to be occurring in stratigraphic proximity to organic-rich zones.

\section{CONCLUSIONS}

Elemental chemostratigraphy based on changes in major and trace elements and element ratios is used to subdivide the Niobrara Member of the Mancos Shale into six chemostratigrpahic zones (CN1 to $\mathrm{CN} 6)$. Chemostratigraphic correlations from nine wells show that four markers identified on the geochemical logs correspond to markers used for lithostratigraphic correlations, which highlights the potential of chemostratigraphy as an independent tool for stratigraphic correlations.

The geochemical data were also used to infer stratigraphic and lateral changes in the depositional environment of the Niobrara Member. Trace elements Mo, Cr, and V indicate that during deposition of the Niobrara Member, more anoxic conditions were present to the east of the study area and that lower oxygenation levels existed during deposition of the stratigraphically upper intervals. Elements Ti, Si, K, and $\mathrm{Al}$ show the occurrence of two to three pulses of increased terrestrial input from a source area to the northwest. The geochemical logs suggest that when terrestrial input was increasing, bottom-water conditions were at their least reducing. 
Cross-plots of Si vs. Al show a positive relationship indicating that the quartz in the Niobrara Member is dominantly detrital in origin, whereas cross-plots of Si and Ca show that the Niobrara Member gradually moves away from its bimodal (clastic/carbonate) character identified in the eastern and central portions of the Western Interior Seaway.

Total Organic Carbon (TOC) calculated for 68 wells using a sonic-resistivity overlay analysis technique $(\Delta \log \mathrm{R})$ and calibrated to measurements from available TOC data show that TOC varies laterally and stratigraphically throughout the study area. TOC values tend to be highest to the south and west of the study area and TOC profiles identify three organically-rich intervals within the Niobrara Member. The $\Delta$ Log R technique of Passey et al. (1990) shows reasonable results when compared to measured TOC data. Level of organic metamorphism (LOM) maps (from \%Ro data conversions) show that the Niobrara Member is more thermally mature within the east-central parts of the basin, where LOM values are as high as 11 (corresponding to $1.2 \% \mathrm{Ro}$ ).

Interpretations of relative changes in rock brittleness made using geochemical data coupled with TOC profiles show that the Niobrara Member is composed of alternating brittle and ductile rocks. Organic (TOC)- and clay-mineral rich intervals are considered mechanically ductile, while more $\mathrm{Si} / \mathrm{Al}$ (quartz/clay) and Ca-enriched rocks are considered mechanically brittle. 


\section{REFERENCES}

Algeo, T. J. and T. W. Lyons, 2006, Mo-total organic carbon covariation in modern anoxic marine environments: implications for analysis of paleoredox and paleohydrographic conditions: Paleoceaonography, v. 21, PA1016, doi: 10.1029/2004PA001112, 2006.

Ball, B. A., W. A. Cobban, E. A. Merewether, R. I. Grauch, K. C. McKinney, and K. E. Livo, 2009, Fossils, lithologies, and geophysical logs of the Mancos Shale from core hole USGS CL-1 in Montrose County, Colorado: U.S. Geological Survey Open-File Report 2009-1294, 38 p.

Barlow, L. K., and E. G. Kauffman, 1985, Depositional cycles in the Niobrara Formation, Colorado Front Range: in L. M. Pratt, E. G. Kauffman, and F. B. Zelt, eds, Fine-grained deposits and biofacies of the Cretaceous Western Interior Seaway, Evidence of cyclic sedimentary processes, SEPM Second Annual Midyear Meeting, Golden, CO, Field trip no. 9, p. 199-208.

Berrang, P. and E. Grill, 1974, The effect of manganese oxide scavenging on molybdenum in Saanich Inlet, British Columbia: Marine Chemistry, v. 2, p. 125-148.

Brumsack, H. J., 2006, The trace metal content of recent organic carbon-rich sediments: Implications for Cretaceous black shale formation: Paleogeography, Paleoclimatology, Paleoecology, v. 232, p. 344-361.

Cardneaux, A. P., 2010, Mapping of the oil window in the Eagle Ford shale play of southwest Texas using thermal modeling and log overlay analysis, Master's thesis, Louisiana State University, Baton Rouge, Louisiana, 74 p.

Clayton, J. L. and P. J. Swetland, 1980, Petroleum generation and migration in Denver basin: AAPG Bulletin, v. 64, no. 10, p. 613-1633.

Cole, R. D., Young, R. G., and G. C. Willis, 1997, The Prairie Canyon Member, a new unit of the Upper Cretaceous Mancos Shale, west-central Colorado and east-central Utah: Utah Geological Survey, v. 97, no. 4, 23 p.

Cole, R. D. and M. J. Pranter, 2008, From rocks to models: Outcrop-based analysis and statistics for subsurface characterization of fluvial reservoir geometry and connectivity, Williams Fork Formation, Piceance Basin: Williams Fork Consortium - Phase IV Sponsor Field Trip Guidebook, 27-28 September 2008, 79 p.

Dean, W. E., and M. A. Arthur, 1998, Geochemical expression of cyclicity in Cretaceous pelagic limestone sequences: Niobrara Formation, Western Interior Seaway. In: Dean, W. E., Arthur, M. A. (Eds.), Stratigraphy and Paleoenvironments of the Cretaceous Western Interior Seaway, U.S.A: SEPM, Concepts Sedimentology Paleontology, v. 6, p. 227-255. 
DeCelles, P. G. and B. S. Currie, 1996, Long-term sediment accumulation in the Middle Jurassic-Early Eocene Cordilleran retroarc foreland-basin system: Geology, v. 24, no. 7, p. 591-594

Durham, L. S., 2012, What is the tally of Niobrara value?: AAPG Explorer, v. 33, no. 8, p. 20.

Durham, L. S., 2013, Rocky operators cautiously move ahead: AAPG Explorer, v. 34, no.6, p.6, 8.

Ehrenberg, S. N., and E. Siring, 1992, Use of bulk chemical analyses in stratigraphic correlations of sandstones; an example from the Statfjord Nord Field, Norwegian continental shelf: Journal of Sedimentary Research, v. 62, no. 2, p. 318-330.

Finn, T. M. and R. C. Johnson, 2005, Niobrara total petroleum system in the southwestern Wyoming Province (Chapter 6), in Petroleum Systems and Geologic Assessment of Oil and Gas in the Southwestern Wyoming Province, Wyoming, Colorado, and Utah, U.S. Geological Survey Digital Data Series 69-D, 27 p.

Fisher, R., 2007, Stratigraphic, Geochemical and Geomechanical Analysis of the Lower Mancos Shale, Douglas Creek Arch, Northwest Colorado, U.S.A., Master’s thesis, Colorado School of Mines, Golden, Colorado, 164 p.

Gardner, M. H. and T. A, Cross, 1994, Middle Cretaceous paleogeography of Utah, in M. V. Caputo, J. A. Peterson, and K. J. Franczyk, eds., Mesozoic systems of the Rocky Mountain Region, United States: SEPM, Rocky Mountain Section Special Publication, p. 471-502.

Haskett, G. I., 1959, Niobrara Formation of northwest Colorado, Rocky Mountain Association of Geologists Field Conference Guidebook, p. 46-49.

Hoak, T. E. and A. L. Klawitter 1997, Prediction of fractured reservoir production trends and compartmentalization using an integrated analysis of basement structures in the Piceance Basin, western Colorado, in T.E. Hoak, A. L. Klawitter, and P.K. Blomquist, eds., Fractured reservoirs: characterization and modeling: Rocky Mountain Association of Geologist Guidebook, p. 67-102.

Hood, A., Gutjahr, C. C. M., and R. L. Heacock, 1975, Organic Metamorphism and the Generation of Petroleum: AAPG Bulletin, v.59, p. 986-996.

Jenkyns, H. V., 2010, Geochemistry of oceanic anoxic events: Geochemistry Geophysics Geosystems, v. 11, p. 1-30.

Johnson, R. C., 1989, Geologic history and hydrocarbon potential of Late Cretaceous-age lowpermeability reservoirs, Piceance Basin, western Colorado: U.S. Geological Survey Bulletin 1787, $51 \mathrm{p}$. 
Johnson, R. C., 2003, Depositional framework of the Upper Cretaceous Mancos Shale and the lower part of the Upper Cretaceous Mesaverde Group, western Colorado and eastern Utah (Chapter 10), in Petroleum systems and geologic assessment of oil and gas in the Uinta-Piceance Province, Utah and Colorado: U.S. Geological Survey Digital Data Series 69-B, 29 p.

Johnson, R. C. and R.M and Flores, 2003, History of the Piceance Basin from latest Cretaceous through Early Eocene and the characterization of Lower Tertiary sandstone reservoirs: Peterson, K.M., Olson, T.M., and Anderson, D.D., eds., Piceance Basin Guidebook: Rocky Mountain Association of Geologists, p. 21-6

Jones, B. and D. A. C. Manninig, 1994, Comparison of geochemical indices used for the interpretation of paleoredox conditions in ancient mudstones: Chemical Geology, v. 111, p. 111-129.

Kauffman, E. G., 1977, Cretaceous facies, faunas, and paleoenvironments across the Western Interior Basin, in The Mountain Geologist, field guide: North American paleontological Convention II., v.14: The Rocky Mountain Association of Geologists.

King, P. B., 1959, The evolution of North America: Princeton University Press, Princeton, New Jersey, $189 \mathrm{p}$.

Kirschbaum, M. A., 2003, Geologic assessment of undiscovered oil and gas resources of the Mancos/Mowry total petroleum system, Uinta-Piceance Province, Utah and Colorado (Chapter 6) in Petroleum systems and geologic assessment of oil and gas in the UintaPiceance Province, Utah and Colorado: U.S Geological Survey Digital Data Series-69-B, $42 \mathrm{p}$.

Kuzniak, K., 2009, New Stratigraphic Interpretations, Geochemistry, and Petrophysics of the Lower Mancos Group, Douglas Creek Arch, Northwestern Colorado, U.S.A., Master's thesis, Colorado School of Mines, Golden, Colorado, 145 p.

Landon, S. M., Longman, M. W., and B. A. Luneau, 2001, Hydrocarbon source rock potential of the Upper Cretaceous Niobrara Formation, Western Interior Seaway of the Rocky Mountain region: The Mountain Geologist, v. 38, no. 1, p. 1-18.

LeCompte, B. and G. Hursan, 2010, Quantifying source rock maturity from logs: how to get than TOC from Delta Log R: SPE Annual Technical Conference and Exhibition \#133128, Florence, Italy, 19-22 September 2010.

Li, Y. 1982, A brief discussion on the mean oceanic residence time of elements: Geochimica et Cosmochimica Acta, v. 46, p. 2671-2675.

Longman, M. W., Luneau, B. A., and S. M. Landon, 1998, Nature and distribution of Niobrara lithologies in the Cretaceous Western Interior Seaway of the Rocky Mountain Region: The Mountain Geologist, v. 35, no. 4, p. 137-170. 
Mackenzie, F. T. (Ed.), 2005, Sediments, diagenesis, and sedimentary rocks: Treatise on Geochemistry, Elsevier Ltd., Oxford, 425 p.

Magyar, B., Moor, H., and L. Sigg, 1993, Vertical distribution and transport of molybdenum in a lake with a seasonally anoxic hypolimnion: Limnology and Oceanography, p. 521-531.

Meek, F. B. and F. V Hayden, 1861, Descriptions of new Lower Silurian (Primordial), Jurassic, Cretaceous, and Tertiary fossils collected in Nebraska: the Philadelphia Academy of Natural Sciences, v. 13, p. 415-447.

Merewether, E. A., Sawyer, D. A., and W. A. Cobban, 2006, Molluscan fossils and stratigraphic descriptions from the Upper Cretaceous Mancos Shale, west-central Colorado: USGS OFR 2006-1326, 17 p.

Molenaar, C. M. and B. W. Wilson, 1990, The Frontier Formation and associated rocks of Northeastern Utah and Northwestern Colorado: U.S. Geological Survey Bulletin 1787, v. 1787-M, p. 7-37.

Molenaar, C.M. and W.A. Cobban, 1991, Middle Cretaceous Stratigraphy on the south and east sides of the Uinta Basin, Northeastern Utah and Northwestern Colorado: U.S. Geological Survey Bulletin 1787-P, 34 p.

Morse, J., and G. Luther III, 1999, Chemical influences on trace-metal sulfide interactions in anoxic sediments: Geochimica Et Cosmochimica Acta, v. 63, p. 3373-3378.

Negri, A., Ferretti, A., Wagner, T., and P. A. Meyers, 2009, Organic-carbon-rich sediments through the Phanerozoic: processes, progress, and perspectives: Palaeogeography, Palaeoclimatology, Palaeoecology, v. 273, issue 3-4, p. 302-328.

Nuccio, V. F. and C. E. Barker, 1990, Applications of thermal maturation studies to energy exploration: in V. F. Nuccio and C. E. Barker, eds., Applications of thermal maturation studies to energy exploration: Rocky Mountain Section SEPM, Denver, CO, p. 111-120.

Orians, K.J. and K.W Bruland, 1986, The biogeochemistry of aluminum in Pacific Ocean: Earth Planetary Sciences Letter, v. 78, p. 397-410.

Passey, Q. R., S. Creaney, J. B. Kulla, Moretti, F. J., and J. D. Stroud, 1990, A practical model for organic richness from porosity and resistivity logs: AAPG Bulletin, v. 74, p. 17771794.

Pearce, T. J., Besly, B. M., Wray, D. S., and D. K. Wright, 1999, Chemostratigraphy: a method to improve interwell correlation in barren sequences - a case study using onshore Duckmantian/Stephanian sequences (West Midlands, UK): Sedimentary Geology, v. 124, p. 197-220. 
Pearce, T. J., Wray, D. S., Ratcliffe, K. T., Wright, D. K., and A. Moscariello, 2005, Chemostratigraphy of the Upper Carboniferous Schooner Formation, southern North Sea. Carboniferous hydrocarbon geology: the southern North Sea and surrounding onshore areas: Yorkshire Geological Society, Occasional Publications series, v. 7, p. 147164.

Pearce, T. J., Keighley, D., Morgan, T., and S. Flint, 2008, Chemostratigraphy in the Middle Member of the Green River Formation, Central Nine Mile Canyon, Southwest Uinta Basin, Utah: Utah Geological Association, p. 121-128.

Piper, D. Z. and S. E. Calvert, 2009, A marine biogeochemical perspective on black shale deposition: Earth Science Reviews, v. 95, p. 63-96.

Pollastro, R. M. and C. J. Martinez, 1985, Mineral, chemical and textural relationships in rhythmic-bedded, hydrocarbon-productive chalk of the Niobrara Formation. Denver basin, Colorado: The Mountain Geologist, v. 22, no. 2, p. 55-63.

Pranter, M. J., Cole, R. D., Panjaitan, H., and N. K. Sommer, 2009, Sandstone-body dimensions in a lower coastal-plain depositional setting: Lower Williams Fork Formation, Coal Canyon, Piceance Basin, Colorado: AAPG Bulletin, v. 93, no. 10, p 1379 -1401.

Precht, W. F. and R. M. Pollastro, 1985, Organic and Inorganic Constituents of the Niobrara Formation in Weld County, Colorado: in L. M. Pratt, E. G. Kauffman, and F. B. Zelt, eds., Fine-grained deposits and biofacies of the Cretaceous Western Interior Seaway, Evidence of cyclic sedimentary processes, SEPM Second Annual Midyear Meeting, Golden, CO, Field trip Guidebook no. 9, p. 223-249.

Racey, A., Love, M. A., Bobolecki, R. T., and J. N. Walsh, 1995, The use of chemical element analyses in the study of biostratigraphically barren sequences: an example from the Triassic of the central North Sea (UKCS): Geological Society, London, Special Publications, v. 89, no.1, p. 69-105.

Ratcliffe, K. T., Wright, A. M., Hallsworth, C., Morton, A., Zaitlin, B. A., D. Potocki, and Wray, D. S., 2004, An example of alternative correlation techniques in a low-accommodation setting, nonmarine hydrocarbon system: The (Lower Cretaceous) Mannville Basal Quartz succession of southern Alberta: AAPG bulletin, v. 88, p. 1419-1432.

Ratcliffe, K. T., Morton, A. C., Ritcey, D. H., and C. A. Evenchick, 2007, Whole-rock geochemistry and heavy mineral analysis as petroleum exploration tools in the Bowser and Sustut basins, British Columbia, Canada: Bulletin of Canadian Petroleum Geology, v.55, p. 320-336.

Rice, D. D., 1984a, Occurrence of indigenous biogenic gas in organic-rich, immature chalks of Late Cretaceous age, eastern Denver basin: in J. G. Palacas, ed. Geochemistry and source rock potential of carbonate rocks, AAPG Studies in Geology 18, p. 135-150. 
Rice, D. D., 1984b, Relation of hydrocarbon occurrence to thermal maturity of organic matter in the Upper Cretaceous Niobrara Formation, eastern Denver basin: Evidence of biogenic versus thermogenic origin of hydrocarbons: in J. Woodward, F. F. Meissner, and K. L. Clayton, eds., Hydrocarbon Source Rocks of the Greater Rocky Mountain Region, RMAG, Denver, CO, p. 365-368.

Rimmer, S. M., 2004, Geochemical paleoredox indicators in Devonian-Mississippian black shales, Central Appalachian Basin (USA): Chemical Geology, v. 206, p. 373-391.

Roberts, L. N. R. and M. A. Kirschbaum, 1995, Paleogeography of the Late Cretaceous of the Western Interior of middle North America - Coal distribution and sediment accumulation: U.S. Geological Survey Professional Paper 1561, 116 p.

Rogers, N. T., 2012, Subsurface Stratigraphy of the Upper Cretaceous Lower Mancos Formation and Related Units, Piceance Basin, Northwestern Colorado, Master’s thesis, University of Colorado, Boulder, Colorado, 250 p.

Scott, G. R., and W. A. Cobban, 1964, Stratigraphy of the Niobrara Formation at Pueblo, Colorado: USGS Professional Paper, 454-L.

Slatt, R, Abousleiman, Y, 2011, Merging sequence stratigraphy and geomechanics for unconventional gas shales: The Leading Edge v. 30, p. 274-282.

Sondergeld, C. H., Newsham, K. E., Comisky, J. T., Rice, M. C., and C. S. Rai, 2010, Petrophysical Considerations in Evaluating and Producing Shale Gas Resources, SPE 131768, SPE Unconventional Gas Conference, Pittsburgh, Pennsylvania 23-25, 2010.

Sonnenberg, S.A., 2012, The Niobrara Petroleum System, Rocky Mountain Region: Science and Discovery Article \#80206, Adapted from presentation at Tulsa Geological Society dinner meeting, Tulsa, Oklahoma, January 3, 2012.

Tissot, B. P. and D. H. Welte, 1984, Petroleum formation and occurrence: New York, SpringerVerlag, $699 \mathrm{p}$

Tribovillard, N., Algeo, T.J., Lyons, T., and A. Riboulleau, 2006, Trace metals as paleoredox and paleoproductivity proxies: an update: Chemical Geology, v. 232, p. 12-32.

Tribovillard, , N., Bout-Roumazeilles, V., Algeo, T., Lyons, T. W., Sionneau, T., MonteroSerrano, J. C., Riboulleau, A., and F. Baudin, 2008, Paleodepositional conditions in the Orca Basin as inferred from organic matter and trace metal contents: Marine Geology, v. 254, issue 1-2, p. 62-72.

Turgeon, S. and H. J. Brumsack, 2006, Anoxic vs. dysoxic events reflected in sediment geochemistry during the Cenomanian-Turonian Boundary Event (Cretaceous) in the Umbria-Marche Basin of central Italy, Chemical Geology, v. 234, p. 321-339. 
Vincelette, R. R. and N. H. Foster, 1992, Fractured Niobrara of northwestern Colorado, in Schmoker, J. W., Coalson, E. B., and Brown, C. A., eds., Geological studies relevant to horizontal drilling - Examples from western North America: Rocky Mountain Association of Geologists Guidebook, p. 227-239.

Weimer, R. J., 1960, Upper Cretaceous stratigraphy, Rocky Mountain area: AAPG Bulletin, v. 44, p. 1-20.

Wright, A. M., Ratcliffe, K. T., Zaitlin, B. A., and D. S. Wray, 2010a, The application of chemostratigraphic techniques to distinguish compound incised valleys in low accommodation incised valley systems in a foreland basin setting: an example from the Lower Cretaceous Mannville Group and Basal Colorado Sandstone (Colorado Group), Western Canadian Sedimentary Basin: Application of Modern Stratigraphic Techniques: Theory and Case Histories, SEPM, Special Publication, v. 94, p. 93-108.

Wright, A. M. and K T. Ratcliffe, 2010b, Application of Inorganic Whole Rock Geochemistry to Shale Resource Plays: in Canadian Unconventional Resources and International Petroleum Conference, Calgary, Alberta, Canada, 19-21 October 2010, p. 1-18. 
Appendix A

XRF Data Collection 


\begin{tabular}{|c|c|c|c|c|c|c|c|c|c|c|c|c|c|c|c|c|}
\hline 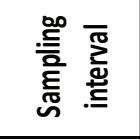 & $\begin{array}{l}+\dot{+} \\
\stackrel{0}{0}\end{array}$ & $\begin{array}{l}+ \\
\stackrel{+}{0} \\
\end{array}$ & $\begin{array}{l} \pm \\
\text { 品 }\end{array}$ & 造 & $\begin{array}{l}+ \\
\stackrel{0}{\circ} \\
\end{array}$ & \begin{tabular}{l|l}
+ \\
\\
\end{tabular} & 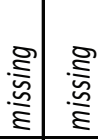 & $\begin{array}{l}+ \\
\\
\end{array}$ & 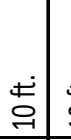 & ث્. & 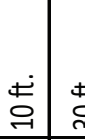 & 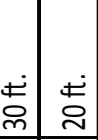 & 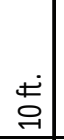 & $\begin{array}{l}+\dot{\oplus} \\
\stackrel{0}{0}\end{array}$ & $\begin{array}{l}+ \\
\\
\end{array}$ & 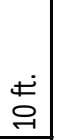 \\
\hline 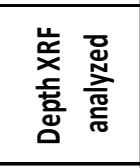 & 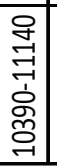 & 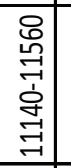 & 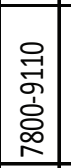 & 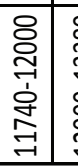 & 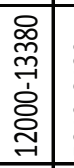 & 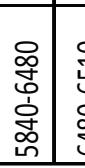 & 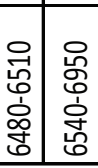 & 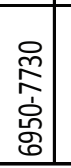 & 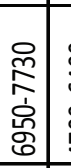 & 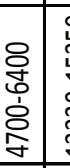 & 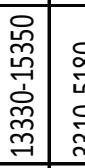 & 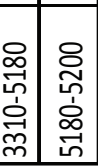 & 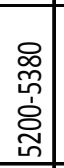 & 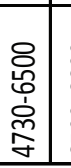 & 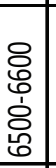 & 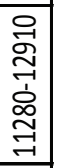 \\
\hline 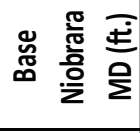 & $\stackrel{\mathscr{J}}{\stackrel{m}{g}}$ & & 怘 & 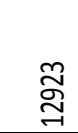 & & & $\underset{ }{\stackrel{Z}{Z}}$ & & & 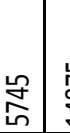 & 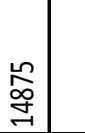 & $\underset{\substack{\infty \\
\stackrel{\infty}{+}}}{ }$ & & 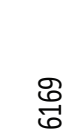 & & 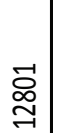 \\
\hline 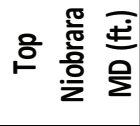 & $\begin{array}{l}\overline{0} \\
\text { Oे }\end{array}$ & & న్ & $\begin{array}{l}\stackrel{0}{二} \\
\stackrel{0}{\exists}\end{array}$ & & & ֻ & & & \begin{tabular}{l|l}
$\mathscr{0}$ \\
\hdashline \\
$\sigma$
\end{tabular} & 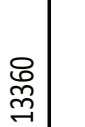 & 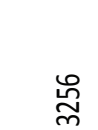 & & $\underset{f}{\stackrel{2}{\rho}}$ & & 兽 \\
\hline 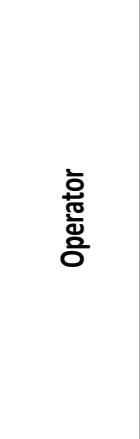 & $\begin{array}{l}\overline{\bar{\sigma}} \\
\overline{\bar{\nu}} \\
\text { o }\end{array}$ & & 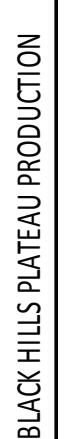 & 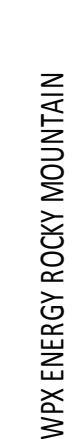 & 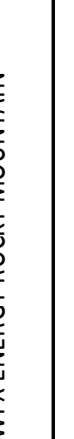 & & $\begin{array}{l}\text { 흐 } \\
\text { ⿱山山⿱ } \\
\text { 옹 } \\
\text { 돈 }\end{array}$ & & & 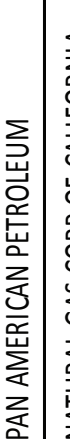 & 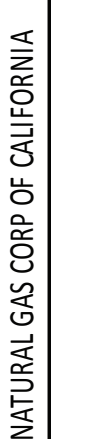 & 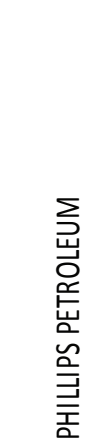 & & 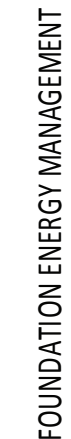 & & 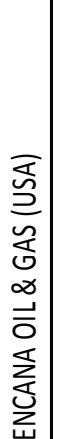 \\
\hline 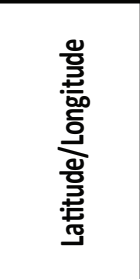 & 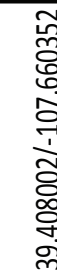 & & 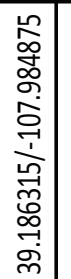 & 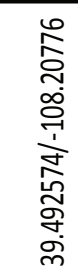 & & & 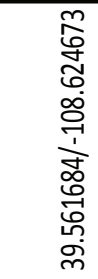 & & & 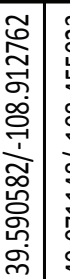 & 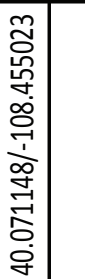 & 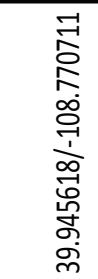 & & 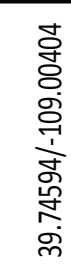 & & 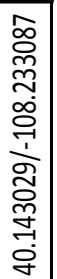 \\
\hline 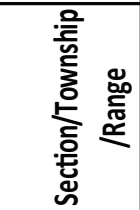 & 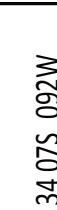 & & 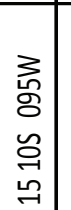 & $\begin{array}{l}3 \\
\text { 옹 } \\
\tilde{8} \\
\vdots \\
\vdots\end{array}$ & & & $\begin{array}{l}3 \\
\text { - } \\
0 \\
\tilde{o} \\
0 \\
0\end{array}$ & & & 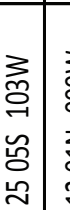 & 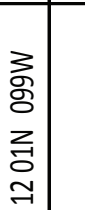 & $\begin{array}{l}3 \\
\text { 竞 } \\
\text { 气̆ } \\
\text { gे }\end{array}$ & & $\begin{array}{l}3 \\
\text { o } \\
0 \\
\widetilde{o} \\
\text { Oे } \\
\vec{m}\end{array}$ & & 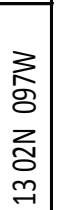 \\
\hline है & 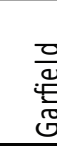 & & 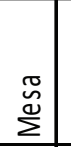 & 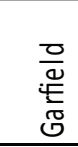 & & & 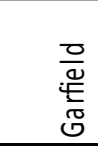 & & & 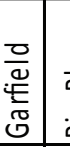 & $\begin{array}{l}\stackrel{8}{c} \\
\frac{c}{\sigma} \\
\frac{0}{\infty} \\
. \frac{0}{x} \\
\end{array}$ & $\begin{array}{l}\stackrel{8}{c} \\
\frac{c}{0} \\
\frac{0}{0} \\
. \frac{0}{x} \\
\end{array}$ & & $\begin{array}{l}8 \\
\frac{8}{\pi} \\
\frac{0}{0} \\
.0 \\
\frac{0}{x}\end{array}$ & & $\begin{array}{l}\frac{0}{c} \\
\frac{\pi}{0} \\
\frac{0}{\infty} \\
\frac{0}{x} \\
\end{array}$ \\
\hline 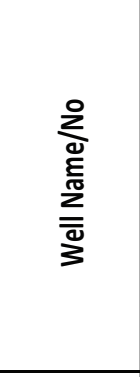 & 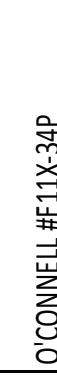 & & 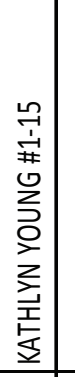 & 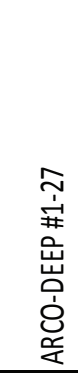 & & & 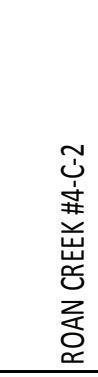 & & & 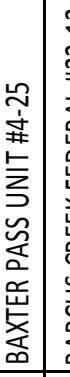 & 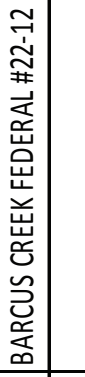 & 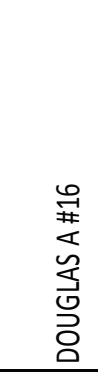 & & 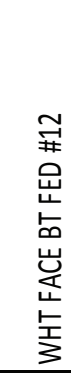 & & 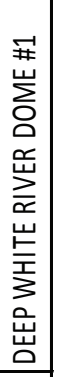 \\
\hline$\frac{\text { 蒿 }}{\overline{\bar{\alpha}}}$ & 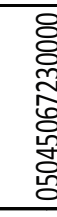 & & 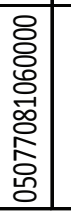 & 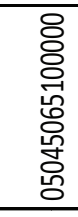 & & & 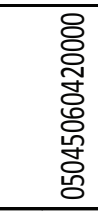 & & & 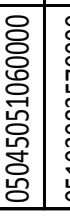 & 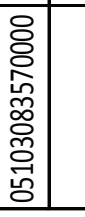 & 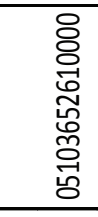 & & 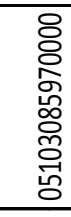 & & 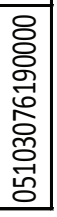 \\
\hline
\end{tabular}




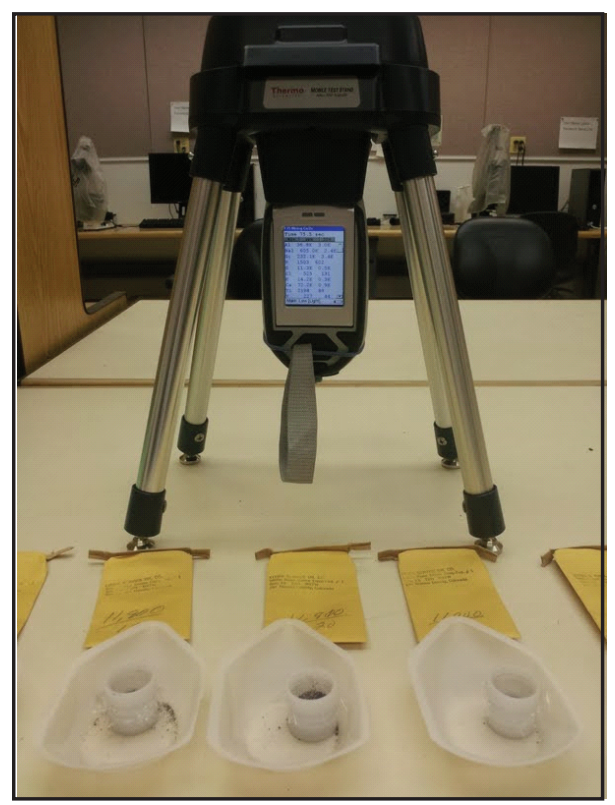

Figure A-1. Thermo Scientific Niton ${ }^{\circledR}$ XL3t Series 950 XRF device and sample cups used in this study.

\section{Measurement modes}

Elements detected in both "mining" and "soils" modes: As, Ca, Cr, Cu, Fe, K, Rb, S, Sr, Ti, and $\mathrm{Zn}$.

Elements only detected in "mining" mode (wt.\%): Al, P, Si, and Zr.

Elements only detected in "soils" mode (ppm): Ba, Mn, Mo, Sc, Te, Th, and V.

Elements (generally) below quantification limit: $\mathrm{Ag}, \mathrm{Au}, \mathrm{Bi}, \mathrm{Cd}, \mathrm{Cl}, \mathrm{Co}, \mathrm{Hg}, \mathrm{Mg}, \mathrm{Nb}, \mathrm{Ni}, \mathrm{Pb}, \mathrm{Pd}$, $\mathrm{Sb}, \mathrm{Se}, \mathrm{Sn}, \mathrm{U}$, and $\mathrm{W}$.

Elements with measurement error >20\%: Ag, As, Cd, Cu, Mg, Pb, Pd, Sc, Se, Sn, and Th.

\section{Precision and repeatability of data}

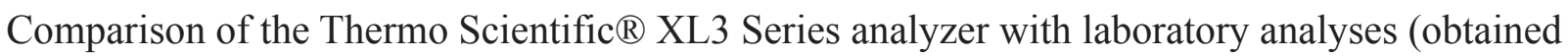
by ICP-MS) on 160 sedimentary rock samples resulted in correlations (R2) $>0.90$ and repeatability $<5 \%$ relative standard deviation for major, minor, and trace elements from $\mathrm{Mg}$ to U. Counting times of 30 seconds on low, main, and high energy filters, and 60 seconds on the light filter. "Studies of solid cores and cuttings provide results within 5 to $20 \%$ of this data quality".

[Thermo Scientific, 2010, Upstream Exploration and Production with the Thermo Scientific Niton XL3t 900 GOLDD Series XRF Analyzer, http://www.niton.com/docs/literature/Upstream_Exploration_Production_with_the_Thermo_Scie ntific_Niton_XL3t_900_GOLDD.pdf?sfvrsn=2, (accessed May 25, 2013)] 
Appendix B

TOC and $\Delta \log R$ 


\begin{tabular}{|c|c|c|}
\hline Method & Description & Reference \\
\hline $\begin{array}{c}\text { Spectral GR - } \\
\text { Uranium } \\
\text { Enrichment }\end{array}$ & $\begin{array}{c}\text { Linear relationship of Uranium (ppm) to Organic } \\
\text { Carbon content for Appalachian Devonian black } \\
\text { shales }\end{array}$ & $\begin{array}{c}\text { Fertl and Rieke 1980, Fertl } \\
\text { and Chilinger 1988, } \\
\text { Guidry and Walsh 1993, } \\
\text { GRI 950496 }\end{array}$ \\
\hline GR Intensity & Derivation of TOC volume from total GR \\
intensity & Fertl and Chilinger 1988 \\
\hline Bulk Density & $\begin{array}{c}\text { Empirical relationship of Bulk Density to TOC } \\
\text { weight \% }\end{array}$ & $\begin{array}{c}\text { Schmoker 1979, } \\
\text { Schmoker and Hester 1983 }\end{array}$ \\
\hline $\begin{array}{c}\text { Gamma Ray } \\
\text { Intensity - } \\
\text { Formation } \\
\text { Density }\end{array}$ & $\begin{array}{c}\text { Derivation of TOC volume from the relationship } \\
\text { of GR intensity and formation density in a } \\
\text { Devonian black shale of the Appalachian basin }\end{array}$ & Schmoker 1981 \\
\hline Delta Log R & Scaled porosity log - resistivity overlay method & Passey et al. 1990 \\
\hline Neural Networks & Usage of conventional well logs to predict TOC & Rezaee et al. 2007 \\
\hline $\begin{array}{c}\text { Pulsed Neutron - } \\
\text { Spectral GR }\end{array}$ & $\begin{array}{c}\text { Pulsed-neutron mineralogy and Spectral Gamma } \\
\text { Ray methodology used to discriminate excess } \\
\text { carbon }\end{array}$ & Pemper et al. 2009 \\
\hline \multicolumn{2}{|c}{} & \\
\hline
\end{tabular}

Table B-1. Summary of geophysical methods to determine Total Organic Carbon from well logs. Adapted from Sondergeld et al. (2010). 
Table B-2. List of wells, associated well-logs, baseline depths, and differential transit time $(\Delta t)$ and Resistivity (R) values at baseline condition used for TOC calculations using the Delta Log R technique.

\begin{tabular}{|c|c|c|c|c|c|c|c|}
\hline County & API\# & Well Name/No & $\begin{array}{c}\text { Section/Township/ } \\
\text { Range }\end{array}$ & \begin{tabular}{|c|} 
Baseline \\
Depth
\end{tabular} & $\Delta$ tbaseline & Rbaseline & $\begin{array}{l}\text { Logs used for } \\
\text { TOC calculation }\end{array}$ \\
\hline Garfield & 0504505106 & BAXTER PASS SOUTH UNIT- G\#4-25 & $2555103 \mathrm{~W}$ & 3500 & 78.241 & 9.882 & 2DT, ILD \\
\hline Garfield & 0504505108 & GOVERMENT BUTTRAM\#1 & $3055102 \mathrm{~W}$ & 2500 & 82.117 & 7.587 & $7 D T, I L D$ \\
\hline Garfield & 0504505112 & SOUTH BAXTER PASS UNIT\#Z2-20 & $2055102 \mathrm{~W}$ & 2900 & 97.101 & 4.583 & 3 DT, ILD \\
\hline Garfield & 0504506009 & NORTH RIFLE UNIT\#1 & $314593 \mathrm{~W}$ & 11000 & 69.237 & 7.519 & DT, SN \\
\hline Garfield & 0504506212 & GENTRY 6-5-103\#1 & $655103 \mathrm{~W}$ & 3500 & 74.587 & 16.837 & $7 D T, \| L D$ \\
\hline Garfield & 0504506286 & BEAR GULCH \#26-2 & $2655101 \mathrm{~W}$ & 6000.5 & 77.884 & 10.201 & $1 \mathrm{DT}, \| \mathrm{LD}$ \\
\hline Garfield & 0504506294 & Twin Buttes \#7101 & $2355102 \mathrm{~W}$ & 4000 & 80.228 & 8.191 & 1 DT, ILD \\
\hline Garfield & 0504506510 & ARCO DEEP \#1-27 & $276597 \mathrm{~W}$ & 10000 & 65.578 & 11.875 & $5 \mathrm{DT}, \| \mathrm{LD}$ \\
\hline Garfield & 0504506572 & Cedar Bench Federal \#6307 & $2865100 \mathrm{~W}$ & 5000 & 84.723 & 6.598 & 8 DT, ILD \\
\hline Garfield & 0504506688 & Cedar Bench Federal \#6305 & $1765100 \mathrm{~W}$ & 5000.092 & 75.999 & 9.011 & $1 \mathrm{DT}, \| \mathrm{LD}$ \\
\hline Garfield & 0504506723 & O'CONNELL\#F11X-34P & $347592 \mathrm{~W}$ & 9500 & 72.142 & 9.885 & 5 DT, ILD \\
\hline Garfield & 0504506728 & NARCO FEDERAL & $165100 \mathrm{~W}$ & 6000 & 77.292 & 8.156 & 6DT, ILD \\
\hline Garfield & 0504506752 & FEDERAL & $1765100 \mathrm{~W}$ & 5000 & 78.061 & 7.226 & 6 DT, ILD \\
\hline Garfield & 0504506759 & CEDAR BENCH UNIT \#6308 & $1565100 \mathrm{~W}$ & 6500 & 85.385 & 6.333 & DT, ILD \\
\hline Garfield & 0504506776 & DESERT STORM UNIT\#1 & $347598 \mathrm{~W}$ & 6500 & 76.233 & 10.289 & $9 \mathrm{DT}, \mathrm{IDPH}$ \\
\hline Garfield & 0504506913 & Standard Shale \#6401 & $97599 \mathrm{~W}$ & 6000.303 & 74.228 & 9.458 & DT, AF90 \\
\hline Garfield & 0504506914 & STANDARD SHALE \#6402 & $117599 \mathrm{~W}$ & 6500.098 & 82.314 & 5.463 & DT, AF9O \\
\hline Mesa & 0507708901 & ORCHARD UNIT\#17-13DT(M170U) & $178596 \mathrm{~W}$ & 7500 & 76.568 & 7.694 & DT, ILD \\
\hline Moffat & 0508106090 & LYNCH CREEK-GOV \#1 & $163 \mathrm{~N}$ 90W & 2500.5 & 81.713 & 10.284 & $A D T, I L D$ \\
\hline Rio Blanco & 0510305835 & BRADSHAW (GOV) \#1 & $82 \mathrm{~N} 93 \mathrm{~W}$ & 5000 & 81.708 & 7.95 & 5 DT, ILD \\
\hline Rio Blanco & 0510305920 & DAVID RSEELYY G\#1 & $233 \mathrm{~N} 90 \mathrm{~W}$ & 1500 & 87.329 & 10.011 & 1 DT, ILD \\
\hline Rio Blanco & 0510306377 & ERVING WOLF GOV\#1-A & $271 \mathrm{~N} 102 \mathrm{~W}$ & 4000 & 100.049 & 7.088 & $8 D T, I L D$ \\
\hline Rio Blanco & 0510306432 & WILSON CREEK UNIT\#50 & $193 \mathrm{~N} 94 \mathrm{~W}$ & 4500 & 88.831 & 6.603 & DTT,SN \\
\hline Rio Blanco & 0510307261 & DOUGLAS PASS UNIT \#\#1 (33-10) & $1015101 \mathrm{~W}$ & 4000.043 & 83.236 & 7.161 & $1 D T$, ILD \\
\hline Rio Blanco & 0510307265 & WILSON CREEK UNIT\#53 & $233 \mathrm{~N} 94 \mathrm{~W}$ & 4000 & 96.958 & 6.331 & 1 DT, SN \\
\hline Rio Blanco & 0510307432 & EAST RANGELY\#1-14 & $141 \mathrm{~N} 100 \mathrm{~W}$ & 7000 & 81.044 & 6.508 & 8DT, ILD \\
\hline Rio Blanco & 0510307619 & DEEP WHITE RIVER DOME\#1 & 132N 97W & 10500.055 & 67.113 & 6.15 & $5 D T, I L D$ \\
\hline Rio Blanco & 0510307859 & TAIGA-GREAT BASINS\#1-17 & $1745103 \mathrm{~W}$ & 3000 & 73.157 & 12.691 & 1 DT, ILD \\
\hline Rio Blanco & 0510308197 & COLOROW-GULCHFEDERAL\#15-29 & $293 \mathrm{~N} 97 \mathrm{~W}$ & 6500 & 84.981 & 6.126 & 6DT, ILD \\
\hline
\end{tabular}




\begin{tabular}{|c|c|c|c|c|c|c|c|}
\hline County & API\# & Well Name/No & $\begin{array}{c}\text { Section/Township/ } \\
\text { Range }\end{array}$ & $\begin{array}{c}\text { Baseline } \\
\text { Depth }\end{array}$ & $\Delta$ tbaseline & Rbaseline & \begin{tabular}{|l} 
Logs used for \\
TOC calculation
\end{tabular} \\
\hline Rio Blanco & 0510308212 & SOLDIER CANYON\#3O-3 & $3045100 \mathrm{~W}$ & 6000.141 & 74.14 & 10.537 & 37 DT, ILD \\
\hline Rio Blanco & 0510308452 & THUNDER FED \#13-9-4-102 & $945102 \mathrm{~W}$ & 3000 & 81.996 & & $49 \overline{D T}, I L D$ \\
\hline Rio Blanco & 0510308461 & FEDERAL \#9-25-1-2 & $2515102 \mathrm{~W}$ & 2900 & 86.457 & & \begin{tabular}{l|l}
3 & DT, ILD \\
\end{tabular} \\
\hline Rio Blanco & 0510308603 & ROCK CANYON FED \#2-34-4-101 & $3445101 \mathrm{~W}$ & 4000 & 75.318 & 11.559 & 590 \\
\hline Rio Blanco & 0510308678 & WHITEFACE BT FED \#1-23-3-104 & $2335104 \mathrm{~W}$ & 4500 & 73.63 & 14.283 & $83 \mathrm{DT}, \mathrm{LD}$ \\
\hline Rio Blanco & 0510308824 & FEDERAL\#7-12-4-104 & $1245104 \mathrm{~W}$ & 3500 & 74.349 & 16.092 & $22 \mathrm{DT}, \mathrm{RD}$ \\
\hline Rio Blanco & 0510308825 & COLUMBINESP \#8-11-4-104 WD & $1145104 \mathrm{~W}$ & 3500 & 74.08 & 14.892 & \begin{tabular}{l|l}
92 & $D T, L L D$ \\
\end{tabular} \\
\hline Rio Blanco & 0510308891 & FEDERAL\#6-23-4-104 & $2345104 \mathrm{~W}$ & 4500 & 78.342 & 14.186 & $\begin{array}{l}36 \\
D T, L L D \\
\end{array}$ \\
\hline Rio Blanco & 0510308920 & FEDERAL \#6-22 & $221 \mathrm{~N} 103 \mathrm{~W}$ & 4000 & 80.345 & & $56 \mid D T, L L D$ \\
\hline Rio Blanco & 0510308951 & PMF \#9007 & $1435104 \mathrm{~W}$ & 5000 & 76.309 & 13.293 & $93 \mid D T, L L D$ \\
\hline Rio Blanco & 0510308967 & FEDERAL\#12-19-1N-102 & $191 \mathrm{~N} 102 \mathrm{~W}$ & 4000 & 83.371 & & $16 \mid D T, L L D$ \\
\hline Rio Blanco & 0510308982 & TAIGA MTN \#6-14-1-103 & $141 \mathrm{~N} 103 \mathrm{~W}$ & 5000 & 80.604 & 10.954 & 54 DT, LLD \\
\hline Rio Blanco & 0510308998 & MOORE \#2-12MH & $121 \mathrm{~N} 93 \mathrm{~W}$ & 2000 & 86.699 & 11.742 & A2 DT, LLD \\
\hline Rio Blanco & 0510309022 & COSEKA \#3-20-IN-103 & $201 \mathrm{~N} 103 \mathrm{~W}$ & 5500 & 82.553 & & $97 \mid D T, L L D$ \\
\hline Rio Blanco & 0510309073 & FEE \#10-1-1S-104 & $115104 \mathrm{~W}$ & 6000 & 84.461 & & $19 \mid D T, L L D$ \\
\hline Rio Blanco & 0510309092 & SOLDIER CANYON \#25-4 & $2545101 \mathrm{~W}$ & 4500 & 79.679 & 10.444 & A4 DT, LLD \\
\hline Rio Blanco & 0510309093 & SOLDIER CANYON \#26-4 & $2645101 \mathrm{~W}$ & 3000 & 83.307 & 10.023 & 23 DT, LLD \\
\hline Rio Blanco & 0510309098 & SOLDIER CANYON \#35-1 & $3545101 \mathrm{~W}$ & 3000 & 81.566 & & $3 \overline{D T}$, LD \\
\hline Rio Blanco & 0510309164 & PMF \#9003 & $235104 \mathrm{~W}$ & 5000 & 72 & 12.677 & $77 \mid D T, I L D$ \\
\hline Rio Blanco & 0510309167 & HH\#9119 & $125104 \mathrm{~W}$ & 3000 & 77.9 & 11.967 & $67 \mid D T, I L D$ \\
\hline Rio Blanco & 0510309170 & P M FEDERAL \#1-26-2-104 & $2625104 \mathrm{~W}$ & 5000 & 73.204 & & $77 D T, I L D$ \\
\hline Rio Blanco & 0510309192 & HH\#9102 & $3615104 \mathrm{~W}$ & 3500.019 & 78.356 & 10.715 & $15 \mathrm{DT}, \mathrm{LD}$ \\
\hline Rio Blanco & 0510309259 & RABBIT MOUNTAIN \#6-1 & $625103 \mathrm{~W}$ & 4000 & 77.026 & & $8 \mathrm{DT}, \mathrm{LD}$ \\
\hline Rio Blanco & 0510309262 & FOURMILEFEDERAL\#1-28 & $2815101 \mathrm{~W}$ & 3000.146 & 82.079 & 10.448 & $\begin{array}{ll}48 & D T, L L D \\
\end{array}$ \\
\hline Rio Blanco & 0510309267 & H H FEDERAL\#Z2-31-1-103 & $3115103 \mathrm{~W}$ & 5000 & 85.172 & 5.599 & 99 DT, RILD \\
\hline Rio Blanco & 0510309270 & PMF \#9008 & $135104 \mathrm{~W}$ & 4000 & 75.7 & 13.143 & \begin{tabular}{|l|l|}
3 & $D T, I L D$ \\
\end{tabular} \\
\hline Rio Blanco & 0510309279 & HH\#9114 & $3115103 \mathrm{~W}$ & 5000.091 & 84.096 & 6.779 & $79 \mathrm{DT}, \mathrm{LD}$ \\
\hline Rio Blanco & 0510309294 & HH\#9113 & $1425104 \mathrm{~W}$ & 4000 & 77.1 & 12.218 & $18 \mathrm{DT}, \mathrm{LD}$ \\
\hline Rio Blanco & 0510309331 & RM\#9109 & $725103 \mathrm{~W}$ & 5000 & 78.9 & & $27 \mid D T, I L D$ \\
\hline Rio Blanco & 0510309385 & HH\#9105 & $125104 \mathrm{~W}$ & 4000 & 76.256 & & $72 \mathrm{DT}, \mathrm{LD}$ \\
\hline Rio Blanco & 0510309462 & PARK MOUNTAIN \#9015 & $1235104 \mathrm{~W}$ & 4500 & 84.417 & 8.613 & \begin{tabular}{l|l}
13 & $D T, \| L D$ \\
\end{tabular} \\
\hline Rio Blanco & 0510309623 & HH\#9107 & $1125104 \mathrm{~W}$ & 3500 & 78.2 & 11.739 & 39 DT, AF90 \\
\hline Rio Blanco & 0510309624 & HH\#9111 & $1425104 \mathrm{~W}$ & 4000 & 73.088 & 10.308 & \begin{tabular}{l|l}
08 & $D T, / L D$ \\
\end{tabular} \\
\hline Rio Blanco & 0510309625 & PMF \#9009 & $135104 \mathrm{~W}$ & 5000 & 80.2 & 10.819 & \begin{tabular}{l|l}
19 & DT, AF90
\end{tabular} \\
\hline
\end{tabular}




\begin{tabular}{|c|c|c|c|c|c|c|c|}
\hline County & API\# & Well Name/No & $\begin{array}{c}\text { Section/Township/ } \\
\text { Range }\end{array}$ & \begin{tabular}{|c|} 
Baseline \\
Depth
\end{tabular} & $\Delta$ tbaseline & Rbaseline & $\begin{array}{l}\text { Logs used for } \\
\text { TOC calculation }\end{array}$ \\
\hline Rio Blanco & 0510309694 & PMF \#9004 & $3625104 \mathrm{~W}$ & 6000 & 73.3 & 11.233 & DT, ILD \\
\hline Rio Blanco & 0510309775 & PMF \#9011 & $53 \mathrm{~S} 103 \mathrm{~W}$ & 6000.14 & 80.016 & 8.141 & DT, AHT90 \\
\hline Rio Blanco & 0510309844 & PMF \#9016 & $183 S 103 \mathrm{~W}$ & 4500 & 81.241 & 9.601 & DT, AT90 \\
\hline Rio Blanco & 0510309927 & LOWER HORSE DRAW UNIT \#2246 & $292 \mathrm{~S} 103 \mathrm{~W}$ & 4500 & 83.149 & 7.599 & DTCO, AHT90 \\
\hline Rio Blanco & 0510309942 & LOWER HORSE DRAW \#2186 & $2625103 \mathrm{~W}$ & 3150 & 79.48 & 10.404 & DTCO, AHT9O \\
\hline Rio Blanco & 0510310250 & SE RANGELY\#1000 & $331 \mathrm{~N} 101 \mathrm{~W}$ & 3500 & 87.942 & 6.236 & DTCO, AT90 \\
\hline Rio Blanco & 0510365261 & DOUGLAS A \#16 & $191 \mathrm{~S} 101 \mathrm{~W}$ & 3000 & 82.036 & 7.789 & DT, ILD \\
\hline
\end{tabular}

Well Log Acronyms:

AF90, AHT90, AT90: Deep Resistivity Logs

DT: Differential Transit Time Log

IDPH: Deep Induction Phasor Resistivity Log

ILD: Deep Induction Resistivity Log

LLD: Laterlog Deep Resistivity

RD: Deep Resistivity Log

SN: Short Normal Resistivity Log 
Table B-3. Compiled list of LOM values for wells used for TOC calculation using the Delta Log R technique. Columns 4 and 5 are respectively \%Ro data (from USGS CRC data files) averaged over the Niobrara interval and the corresponding conversion to LOM using LeCompte and Hursan's formula (2010). The average \%Ro values are assumed constant over the complete Niobrara Member interval. Column 6 contains assigned LOM values for wells for which no data on maturity level were available.

\begin{tabular}{|c|c|c|c|c|c|}
\hline Well API\# & Well Name/No & $\begin{array}{c}\text { CRC Library } \\
\text { Number }\end{array}$ & $\begin{array}{c}\text { Average } \\
\% \text { Ro }\end{array}$ & $\begin{array}{c}\text { Average } \\
\text { LOM }\end{array}$ & $\begin{array}{c}\text { Sampled } \\
\text { LOM value }\end{array}$ \\
\hline 05029060550000 & SELL ET AL\#1 & DZ 18458 & & 10.45 & \\
\hline 05045051060000 & $\begin{array}{l}\text { BAXTER PASS SOUTH UNIT- } \\
\text { G\#4-25 }\end{array}$ & DZ 13065 & & 7.66 & \\
\hline 05045051080000 & GOVERMENT BUTTRAM \#1 & & & & 8.85 \\
\hline 05045051120000 & $\begin{array}{l}\text { SOUTH BAXTER PASS UNIT } \\
\# 2-20\end{array}$ & DC 01320 & & 8.92 & \\
\hline 05045060090000 & NORTH RIFLE UNIT \#1 & & & & 10.6 \\
\hline 05045062120000 & GENTRY 6-5-103 \#1 & & & & 8.32 \\
\hline 05045062860000 & BEAR GULCH \#26-2 & & & & 9.34 \\
\hline 05045062940000 & Twin Buttes \#7101 & & & & 9.1 \\
\hline 05045063470000 & TATE FEDERAL \#6212 & DZ 18762 & & 8.39 & \\
\hline 05045065100000 & ARCO DEEP \#1-27 & & & & 9.36 \\
\hline 05045065720000 & Cedar Bench Federal \#6307 & & & & 8.51 \\
\hline 05045066880000 & Cedar Bench Federal \#6305 & & & & 8.69 \\
\hline 05045067230000 & O'CONNELL \#F11X-34P & & & & 10.02 \\
\hline 05045067280000 & CEDAR BENCH UNIT \#6308 & & & & 8.89 \\
\hline 05045067520000 & FEDERAL \#22-17 & & & & 8.76 \\
\hline 05045067590000 & CEDAR BENCH UNIT \#6308 & & & & 8.84 \\
\hline 05045067760000 & DESERT STORM UNIT \#1 & & & & 8.59 \\
\hline 05045069130000 & Standard Shale \#6401 & & & & 8.32 \\
\hline 05045069140000 & STANDARD SHALE \#6402 & & & & 8.43 \\
\hline 05077051230000 & DIVIDE CREEK UNIT \#1 & DZ 03996 & & 9.61 & \\
\hline 05077080420000 & MORAN \#27-2 & DZ15803 & & 9.44 & \\
\hline 05077081060000 & KATHLYN YOUNG\#1-15 & DZ 16640 & & 10.16 & \\
\hline 05077089010000 & $\begin{array}{l}\text { ORCHARD UNIT \#17-13DT } \\
\text { (M17OU) }\end{array}$ & & & & 9.32 \\
\hline 05081060900000 & LYNCH CREEK-GOV\#1 & DZ 13987 & & 8 & \\
\hline 05103058350000 & BRADSHAW (GOV) \#1 & & & & 9.87 \\
\hline 05103059200000 & DA VID R SEELY G\#1 & & & & 7.78 \\
\hline 05103063770000 & ERVING WOLF GOV\#1-A & & & & 6.6 \\
\hline 05103064320000 & WILSON CREEK UNIT \#50 & & & & 10.04 \\
\hline 05103072610000 & $\begin{array}{l}\text { DOUGLAS PASS UNIT \#\#1 (33- } \\
\text { 10) }\end{array}$ & & & & 8.18 \\
\hline
\end{tabular}




\begin{tabular}{|c|c|c|c|c|c|}
\hline Well API\# & Well Name/No & $\begin{array}{c}\text { CRC Library } \\
\text { Number }\end{array}$ & $\begin{array}{c}\text { Average } \\
\% \mathrm{Ro}\end{array}$ & $\begin{array}{c}\text { Average } \\
\text { LOM }\end{array}$ & \begin{tabular}{|c|} 
Sampled \\
LOM value
\end{tabular} \\
\hline 05103072650000 & WILSON CREEK UNIT \#53 & & & & $\begin{array}{r}9.92 \\
\end{array}$ \\
\hline 05103074320000 & EAST RANGELY\#1-14 & & & & 9.08 \\
\hline 05103076190000 & DEEP WHITE RIVER DOME\# 1 & & & & 10.2 \\
\hline 05103076390000 & MORAN\#27-2 (PL27SW) & DZ 15984 & & 8.78 & \\
\hline 05103078590000 & TAIGA-GREAT BASINS \#1-17 & & & & 7.87 \\
\hline 05103080960000 & FEDERAL 1-30\#1 & DZ 16747 & & 9.38 & \\
\hline 05103081290000 & FEDERAL MILK CREEK \#21-28 & DZ 16910 & & 8.76 & \\
\hline 05103081830000 & CORRAL CREEK \#4512 & DZ 17290 & & 10.45 & \\
\hline 05103081970000 & $\begin{array}{l}\text { COLOROW-GULCH FEDERAL } \\
\# 15-29 \\
\end{array}$ & & & & 9.67 \\
\hline 05103082120000 & SOLDIER CANYON \#30-3 & & & & 9.68 \\
\hline 05103084520000 & THUNDER FED \#13-9-4-102 & & & & 8.63 \\
\hline 05103084610000 & FEDERAL \#9-25-1-2 & DZ 17517 & & 7.38 & \\
\hline 05103085680000 & $\begin{array}{l}\text { ROCK CANYON FED \#9-34-4- } \\
101\end{array}$ & DZ 17850 & & 10.63 & \\
\hline 05103085970000 & $\begin{array}{l}\text { WHT FACE BT FED \#12-31-3S- } \\
103 \\
\end{array}$ & DZ 18106 & & 7.42 & \\
\hline 05103086030000 & $\begin{array}{l}\text { ROCK CANYON FED \#2-34-4- } \\
101\end{array}$ & & & & 9.47 \\
\hline 05103086780000 & $\begin{array}{l}\text { WHITEFACE BT FED \#1-23-3- } \\
104 \\
\end{array}$ & & & & 6.65 \\
\hline 05103088070000 & THEOS \& SON \#1 & DZ 18531 & & 9.29 & \\
\hline 05103088240000 & FEDERAL \#7-12-4-104 & & & & 7.32 \\
\hline 05103088250000 & $\begin{array}{l}\text { COLUMBINE SP \#8-11-4-104 } \\
\text { WD }\end{array}$ & & & & 7.22 \\
\hline 05103088610000 & MOORE\#1-12 MH & DZ 18726 & & 10.41 & \\
\hline 05103088910000 & FEDERAL \#6-23-4-104 & & & & 7.46 \\
\hline 05103089200000 & FEDERAL \#6-22 & & & & 5.44 \\
\hline 05103089510000 & PMF \#9007 & & & & 6.22 \\
\hline 05103089670000 & FEDERAL \#12-19-1N-102 & & & & 5.7 \\
\hline 05103089820000 & TAIGA MTN\#6-14-1-103 & & & & 5.25 \\
\hline 05103089980000 & MOORE\#2-12MH & & & & 10.25 \\
\hline 05103090220000 & COSEKA \#3-20-IN-103 & & & & 4.69 \\
\hline 05103090730000 & FEE\#10-1-1S-104 & & & & 4.49 \\
\hline 05103090920000 & SOLDIER CANYON \#25-4 & & & & 9.63 \\
\hline
\end{tabular}




\begin{tabular}{|c|c|c|c|c|c|}
\hline Well API\# & Well Name/No & $\begin{array}{c}\text { CRC Library } \\
\text { Number }\end{array}$ & $\begin{array}{c}\text { Average } \\
\text { \%Ro }\end{array}$ & $\begin{array}{c}\text { Average } \\
\text { LOM }\end{array}$ & $\begin{array}{c}\text { Sampled } \\
\text { LOM value }\end{array}$ \\
\hline 05103090930000 & SOLDIER CANYON \#26-4 & & & & 9.55 \\
\hline 05103090980000 & SOLDIER CANYON\#35-1 & & & & 9.52 \\
\hline 05103091640000 & PMF \#9003 & & & & 5.83 \\
\hline 05103091670000 & HH \#9119 & & & & 4.94 \\
\hline 05103091700000 & P M FEDERAL\#1-26-2-104 & & & & 5.48 \\
\hline 05103091920000 & HH\#9102 & & & & 4.92 \\
\hline 05103092590000 & RABBIT MOUNTAIN\#6-1 & & & & 5.18 \\
\hline 05103092600000 & CONOCO FEDERAL $36 \# 3$ & DZ 20573 & & 6.62 & \\
\hline 05103092620000 & FOURMILE FEDERAL\#1-28 & & & & 8.08 \\
\hline 05103092670000 & H H FEDERAL \#2-31-1-103 & & & & 5.11 \\
\hline 05103092700000 & PMF \#9008 & & & & 6.04 \\
\hline 05103092790000 & HH \#9114 & & & & 5.11 \\
\hline 05103092940000 & HH\#9113 & & & & 5.04 \\
\hline 05103093310000 & RM \#9109 & & & & 5.17 \\
\hline 05103093850000 & $\mathrm{HH} \# 9105$ & & & & 4.98 \\
\hline 05103094620000 & PARK MOUNTAIN\#9015 & & & & 6.13 \\
\hline 05103096230000 & HH \#9107 & & & & 4.85 \\
\hline 05103096240000 & HH\#9111 & & & & 4.97 \\
\hline 05103096250000 & PMF \#9009 & & & & 6.04 \\
\hline 05103096940000 & PMF \#9004 & & & & 5.92 \\
\hline 05103097750000 & PMF \#9011 & & & & 6.18 \\
\hline 05103098440000 & PMF \#9016 & & & & 6.67 \\
\hline 05103099270000 & $\begin{array}{l}\text { LOWER HORSE DRAW UNIT } \\
\text { \#2246 }\end{array}$ & & & & 6.29 \\
\hline 05103099420000 & LOWER HORSE DRAW \#2186 & & & & 6.39 \\
\hline 05103102500000 & SERANGELY\#1000 & & & & 7.51 \\
\hline 05103652610000 & DOUGLAS A \#16 & & & & 7.55 \\
\hline
\end{tabular}


Table B-4. API numbers of wells with TOC data from the Niobrara Member available on the USGS Core Research Center website.

[http://geology.cr.usgs.gov/crc/]

\begin{tabular}{|c|c|c|c|c|}
\hline API\# & Well Name/No & Section/Township/Range & $\begin{array}{c}\text { CRC } \\
\text { Library \# }\end{array}$ & $\begin{array}{c}\text { TOC Data } \\
\text { Depth Interval } \\
\text { (ft.) }\end{array}$ \\
\hline 5029060550000 & SELL ET AL 1 & SESE $1413 \mathrm{~S} 91 \mathrm{~W}$ & DZ18458 & $3085-4335$ \\
\hline 5045051060000 & BAXTER PASS SOUTH UNIT- G 4-25 & SWSW 25 5S $103 W$ & DZ13065 & $2450-6765$ \\
\hline 5045051120000 & SOUTH BAXTER PASS UNIT 2-20 & NWSW 20 5S $102 W$ & DC01320 & $4450-6710$ \\
\hline 5045060380000 & FEDERAL-MAGNUSON 11-16 & NESW $1675103 W$ & DZ15541 & $1408.5-4115$ \\
\hline 5045063470000 & TATE FEDERAL 6212 & NENE $306 \mathrm{~S} 99 \mathrm{~W}$ & DZ18762 & $1405-8785$ \\
\hline 5045065100000 & ARCO DEEP 1-27 & NESW 27 6S 97W & DZ20838 & $9280-13630$ \\
\hline 5077051230000 & DIVIDE CREEK UNIT 1 (1U) & SWNW $368591 \mathrm{~W}$ & DZ03996 & $10245-11245$ \\
\hline 5077080420000 & MORAN 27-2 & NWSW 27 10S 96W & DZ15803 & $3230-7560$ \\
\hline 5077081060000 & KATHLYN YOUNG 1-15 & NWSW $1510 S 95 W$ & DZ16640 & $4250-9150$ \\
\hline 5077083450000 & MCDANIEL 1-11 & NWSE $119594 \mathrm{~W}$ & DZ16222 & $10850-12450$ \\
\hline 5081060900000 & LYNCH CREEK-GOV 1 & SWSW $163 \mathrm{~N}$ 90W & DZ13987 & $4045-4865$ \\
\hline 5097050050000 & UNIT (MILLER) 1 & NWNW $910589 \mathrm{~W}$ & DZ01617 & $1950-3750$ \\
\hline 5103070900000 & FEDERAL 1 (14-15) & SWSW $151 \mathrm{~N} 103 \mathrm{~W}$ & DZ04462 & $3420-7800$ \\
\hline 5103076390000 & SOLDIER CANYON 26-1 & SENW $264 \mathrm{~S} 101 \mathrm{~W}$ & DZ15984 & $965-5970$ \\
\hline 5103080960000 & FEDERAL 1-30 1 & NENE $303 \mathrm{~N} 97 \mathrm{~W}$ & DZ20838 & $9280-13630$ \\
\hline 5103081290000 & FEDERAL MILK CREEK 21-28 & NENW 283 N 92W & DZ16910 & $1180-6620$ \\
\hline 5103081830000 & CORRAL CREEK 4512 & NENE 36 1S 100W & DZ17290 & $8680-11570$ \\
\hline 5103084610000 & FEDERAL 9-25-1-2 & NESE $251 \mathrm{~S} 102 \mathrm{~W}$ & DZ17517 & $3985-5455$ \\
\hline 5103085680000 & ROCK CANYON FED 9 & SENE 34 4S $101 \mathrm{~W}$ & DZ17850 & $4315-6250$ \\
\hline 5103088070000 & THEOS \& SON 1 & SESE $81 \mathrm{~N} 92 \mathrm{~W}$ & DZ18531 & $900-3350$ \\
\hline 5103088610000 & MOORE 1-12 MH & NWNW $121 \mathrm{~N} 93 \mathrm{~W}$ & DZ18531 & $1290-4200$ \\
\hline 5103088820000 & ARCO FED 4- & SWSW 33 4S 103W & DD19204 & $1100-2450$ \\
\hline 5103089200000 & FEDERAL 6-22 & NESW 22 1N 103W & DZ18975 & $4377-7565$ \\
\hline 5103092600000 & CONOCO FEDERAL 363 & NENE $362 \mathrm{~S} 103 \mathrm{~W}$ & DZ20573 & $1720-4680$ \\
\hline 5103104090000 & BANTA RIDGE FED 12A-18-1-103 & SWNW 18 1S 103W & DZ18106 & $1595-6535$ \\
\hline 5103664230000 & U S A-PICEANCE CREEK 52-19G & NWNE $192596 W$ & DZ13902 & $15500-17318$ \\
\hline
\end{tabular}




\section{Assigning LOM values}

LOM sampled values were assigned (for wells with no available maturity data) using the "Sample Grid to Wells" in the map module in IHS Petra. First, a grid is created using LOM values from \%Ro conversions (with a grid size estimated from the well data, and "no trendresidual surface” assigned). Next, LOM values are sampled from the created grid using a minimum-curvature style. This surface style is used to create contour lines that are smooth and evenly spaced. This method was selected because it assumes gently changing petrophysical properties within simple structural settings. A drawback to this method of contouring is its tendency to smooth over some of the variations in data points. 

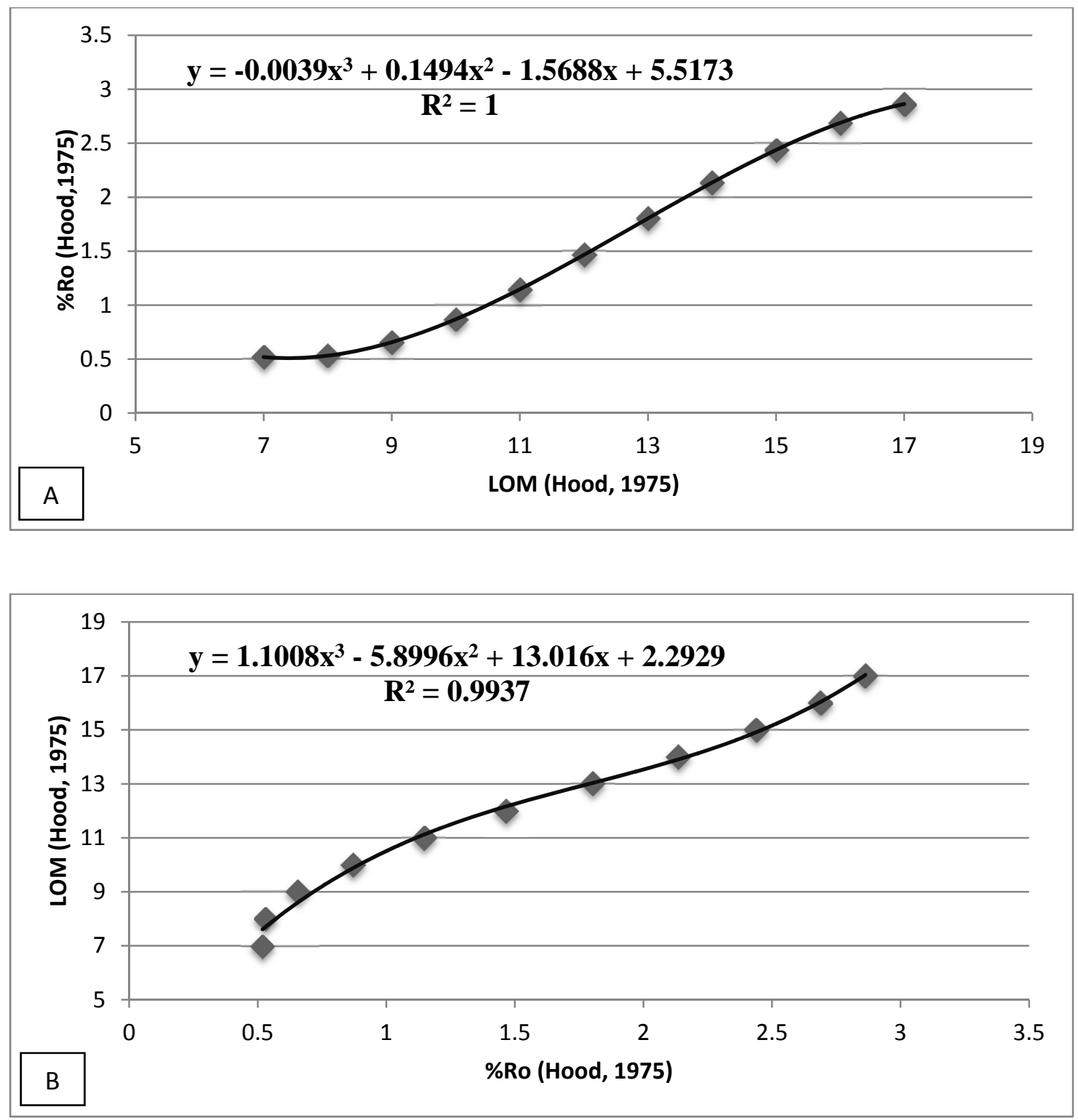

Figure B-1. A- LeCompte and Hursan's (2010) formula to convert LOM to \%Ro.

B- Re-arranged LeCompte and Hursan's formula to solve for LOM using \%Ro. From Cardneaux (2012). 


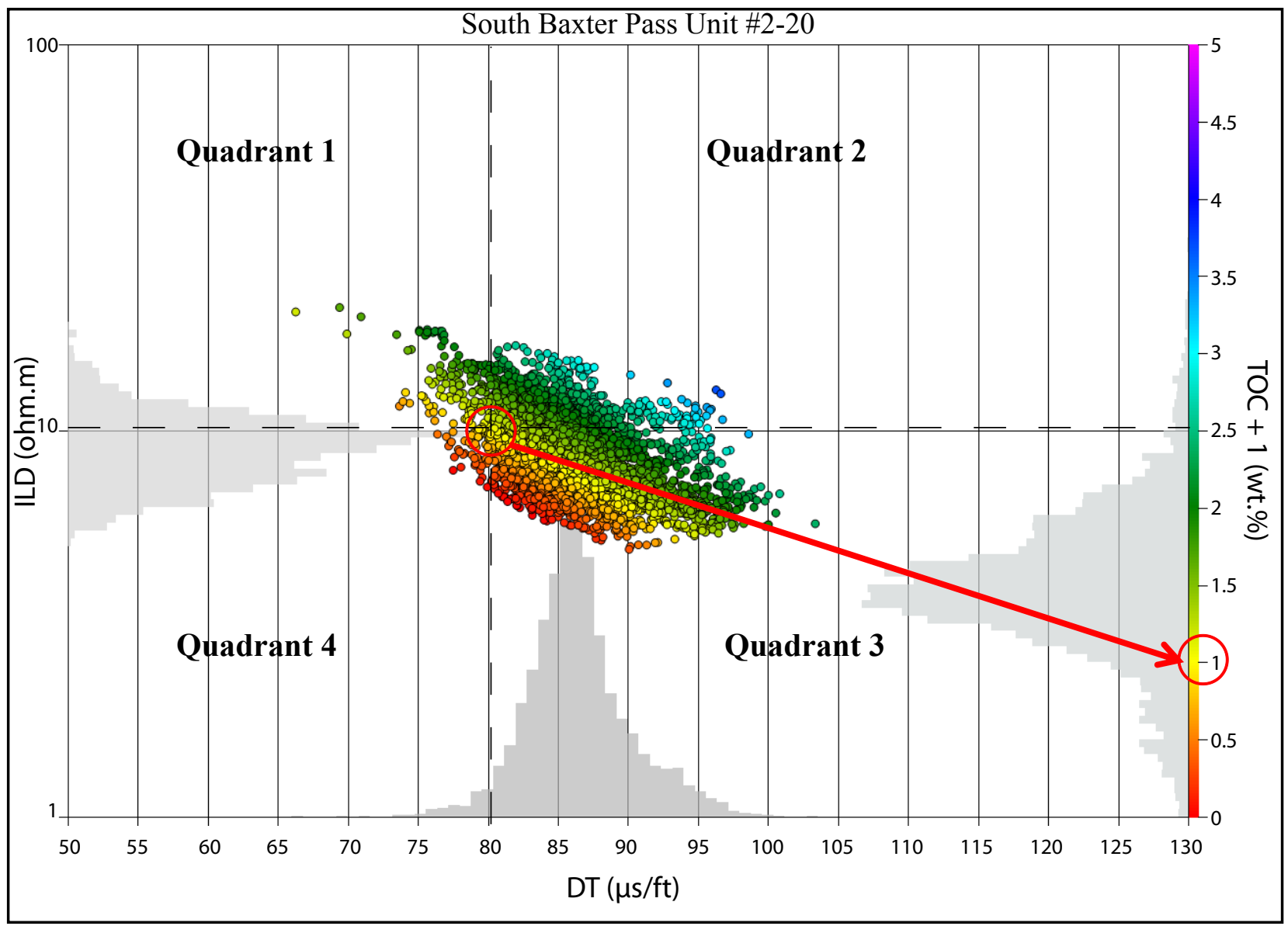

Figure B-2. As detailed in Passey et al. (1990), the $\Delta$ Log $\mathrm{R}$ technique can yield high anomalous TOC values. In order to properly apply this method, only "real" TOC within a source rock interval should be accounted for. Organic content within the studied section is expected to cause a separation resulting from an increase in both the porosity and resistivity values. To qualitatively eliminate what is suggested to be "anomalous" TOC from the TOC curve, a DT/ILD cross-plot for each well was constructed. By choosing a lower TOC cutoff of 1, and determining the area of high TOC values, four quadrants in each cross-plot are identified. Quadrant 1 (high ILD values, low DT values), 3 (high DT values, low ILD values), and 4 (low DT and ILD values) contain data points that are suggested not to cause the proper $\Delta \log \mathrm{R}$ separation, and are therefore removed from the analysis by setting lower values of ILD (=10 ohm.m) and DT (=80 $\mu \mathrm{s} / \mathrm{ft})$. TOC flags are used to identify intervals based on these selected cutoffs, and only those intervals that have ILD and DT values higher than the cutoff values are considered to yield "real" TOC values. The remaining intervals are considered to only have a "background" TOC of 1 wt.\% (Connolly, pers. comm., 2013). 


\section{Appendix C}

\section{Lithostratigraphic Units}

Appendix C contains detailed descriptions (based on well-log signatures) for each

lithostratigraphic unit of the Niobrara Member (Niobrara 1 to Niobrara 8), as well as isopach maps for each unit. 
Detailed Descriptions of the eight lithostratigraphic units (Niobrara 1 to Niobrara 8)

Niobrara 1 is characterized by high gamma-ray values at the base that generally increase upward. Lower gamma-ray values that slightly increase upward are recorded in the upper half of this interval although some exceptions are noted locally (in the southeast, north, and northeast portions of the basin). Resistivity values over much of the basin show an upward increase reaching a local resistivity maximum in some areas. Lithologically, this interval is interpreted to have an overall higher shale content than the underlying intervals (higher gamma-ray values recorded). The top of this interval is defined as a sharp increase on the gamma-ray signature.

Niobrara 2 exhibits a laterally consistent upward-decreasing gamma-ray-log signature trend across the basin. In general, higher resistivity values are recorded at the base of this interval. The dominant lithology is interpreted to be calcareous to very calcareous shale (by comparison to regional work; Vincelette and Foster, 1992; Rogers, 2012).The top of this interval is marked by a subtle decrease in gamma-ray values (Rogers, 2012).

Niobrara 3 also shows an upward-decreasing gamma-ray and resistivity trends. Within this interval, the gamma-ray curve appears to closely track the resistivity curve, with higher gamma-ray values corresponding to higher resistivity values. The overall log-signature trend is not well retained across portions of the basin. The dominant lithology is calcareous sandstone (low gamma-ray values) with interlaminate shale (higher gamma-ray values) (by comparison to regional work; Vincelette and Foster, 1992; Rogers, 2012) overlying carbonaceous to noncalcareous shale. The top of this interval is identified by relatively low values on the gamma-ray curve that are more subtle to the south and southeast portions of the basin. 
Niobrara 4 is characterized by slightly-increasing gamma-ray values and overall higher resistivity values at the base of this interval. The log character in this interval is not well retained in the north and northeast portions of the basin. The top of this unit marks the transition from overall lower (Niobrara 1 to Niobrara 6) to higher gamma-ray values (Niobrara 7 to Niobrara 10) suggesting a shift to higher organic-shale content.

Niobrara 5 is characterized by high overall gamma-ray values that slightly increase upward. Within portions of the basin, high gamma-ray values are recorded at the base of this interval. Resistivity values do not show laterally-consistent trends, although overall, higher values are recorded within the lower half of this interval. Lithologically, this interval is considered limestone-rich facies overlain by calcareous shale (Rogers, 2012). The top of this interval is defined as the uppermost low gamma-ray value.

Niobrara 6 starts with a low gamma-ray value marker that is laterally consistent throughout the study area. Gamma-ray values are generally uniform, although lower values in the upper third of this interval are recorded locally. The dominant lithology is considered to be calcareous to very calcareous shale (by comparison to regional work; Vincelette and Forster, 1992; Rogers, 2012). The top of this interval is defined at the shift to higher gamma-ray values.

Niobrara 7 is characterized by low gamma-ray values that increase upwards. Where this interval is thickest to the northwest, gamma-ray curves first show a decrease followed by an increase in values. This interval is interpreted to be dominantly calcareous to non-calcareous shale (by comparison to regional work; Vincelette and Foster; Rogers, 2012).The top of this interval is a very distinctive high gamma-ray horizon ("Niobrara Hot Shale”) marker, which is considered to be a regionally correlative marker (Rogers, 2012). 
Niobrara 8 is characterized by upward-decreasing gamma-ray values with typically high resistivity values at the base. The dominant lithology is interpreted to be organic-rich shale. The top of this interval (top of Niobrara Member) is picked at a highly-resistive marker which is interpreted to correspond to the top of the calcareous lithology (also noted on PE curve) (Haskett, 1959; Vincelette and Foster, 1992; Finn and Johnson, 2005; Rogers, 2012). 

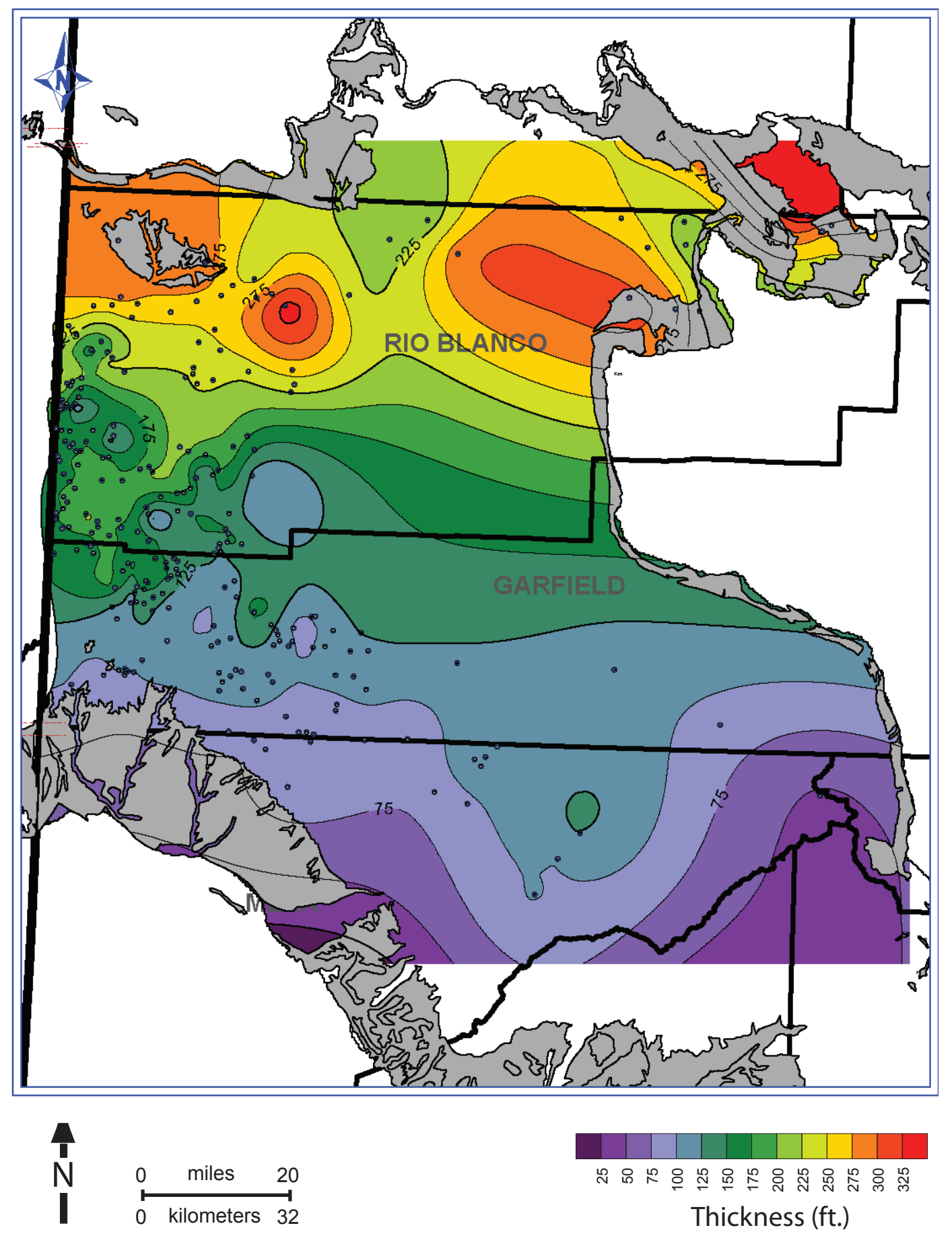

Isopach map of lithostratigraphic unit Niobrara 1. 

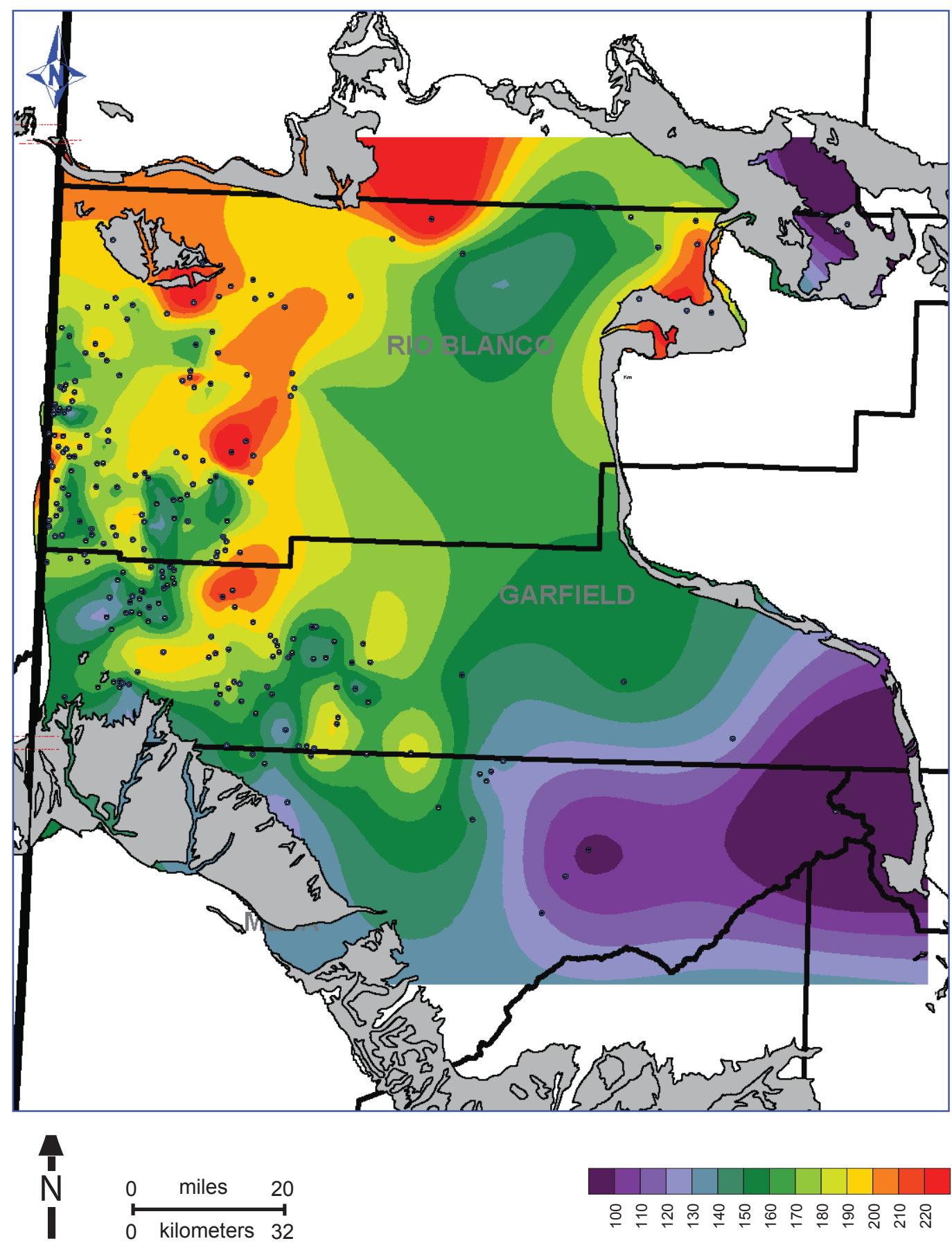

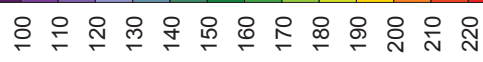

Thickness (ft.)

Isopach map of lithostratigraphic unit Niobrara 2. 

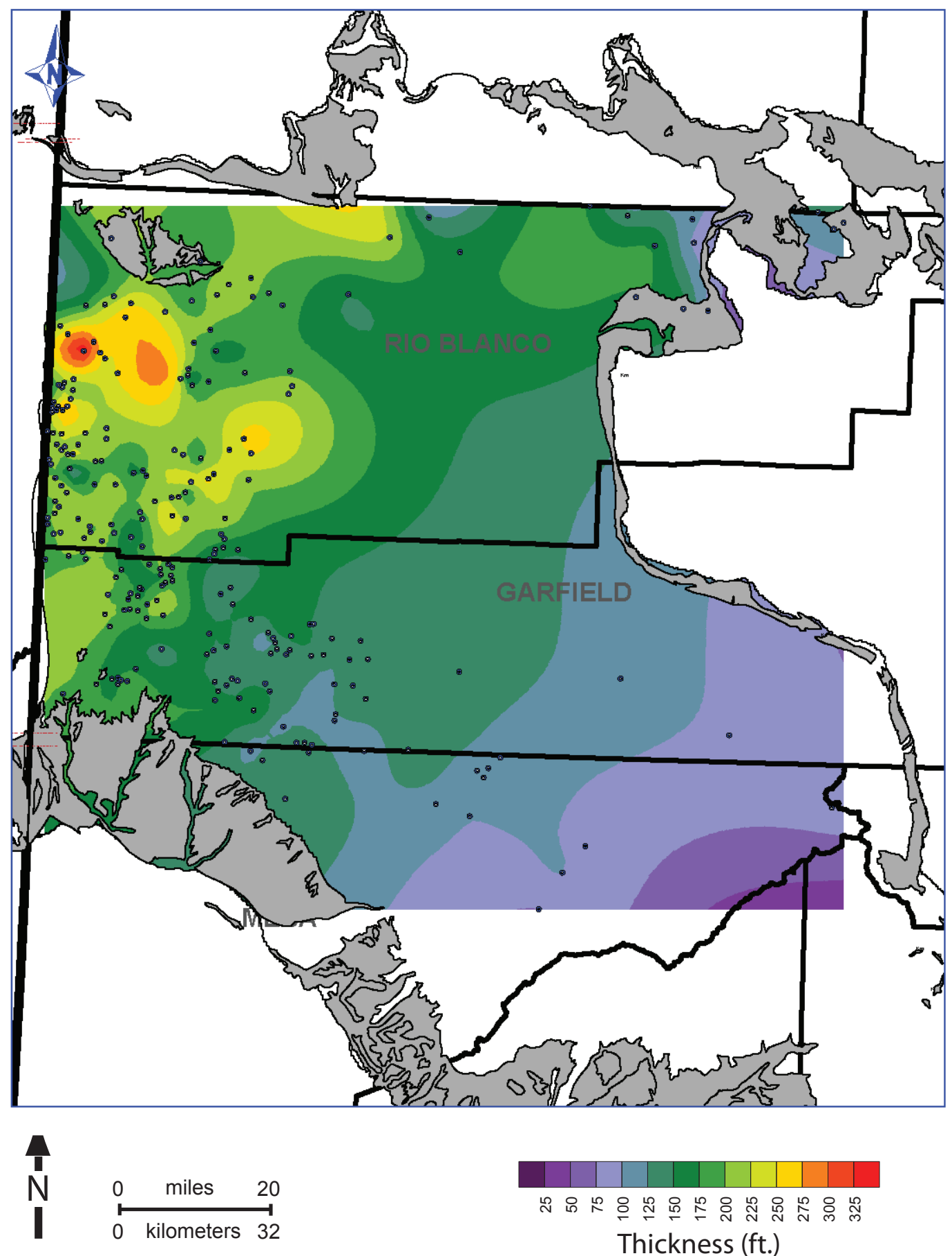

Isopach map of lithostratigraphic unit Niobrara 3. 

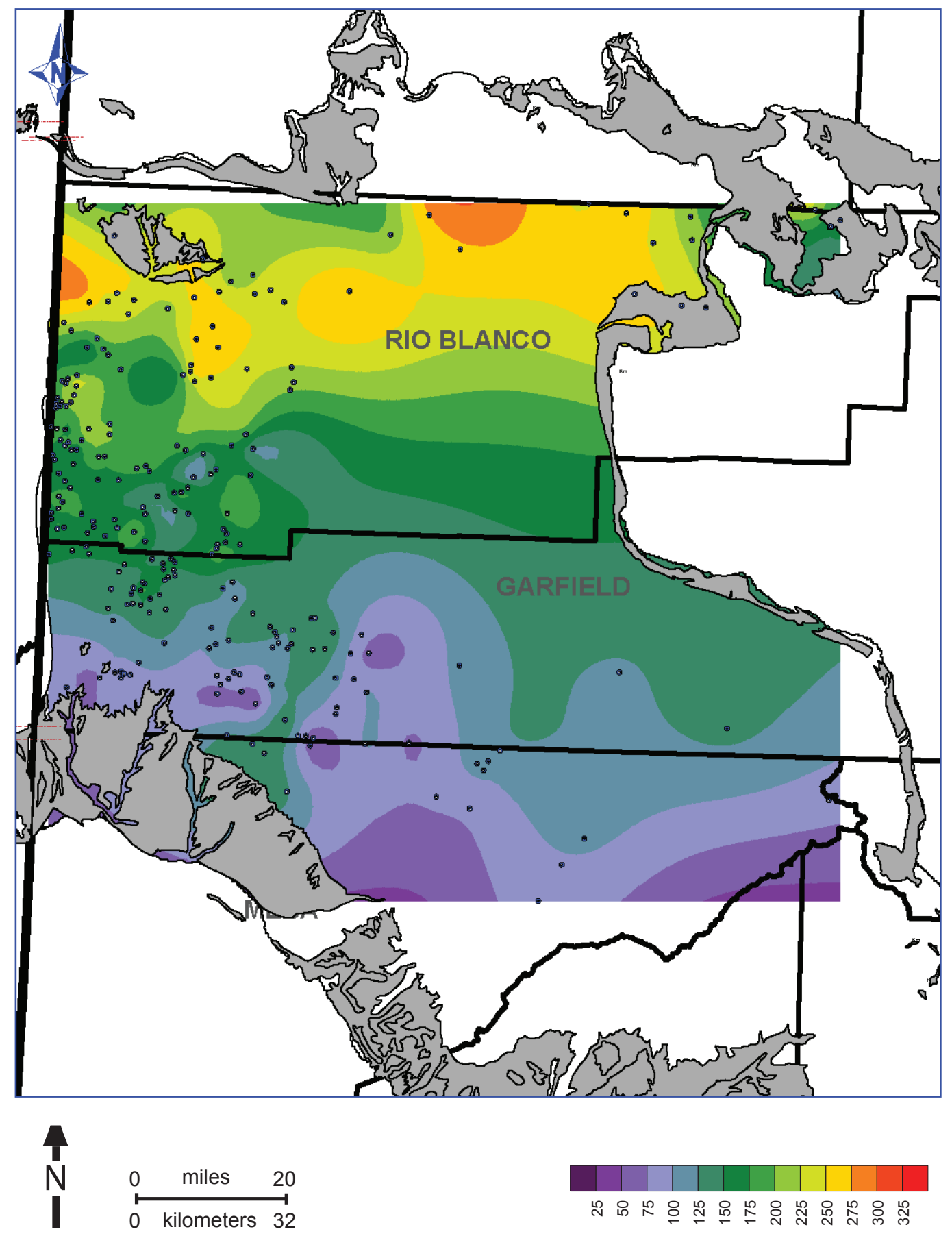

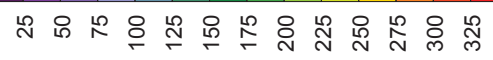

Thickness (ft.)

Isopach map of lithostratigraphic unit Niobrara 4. 


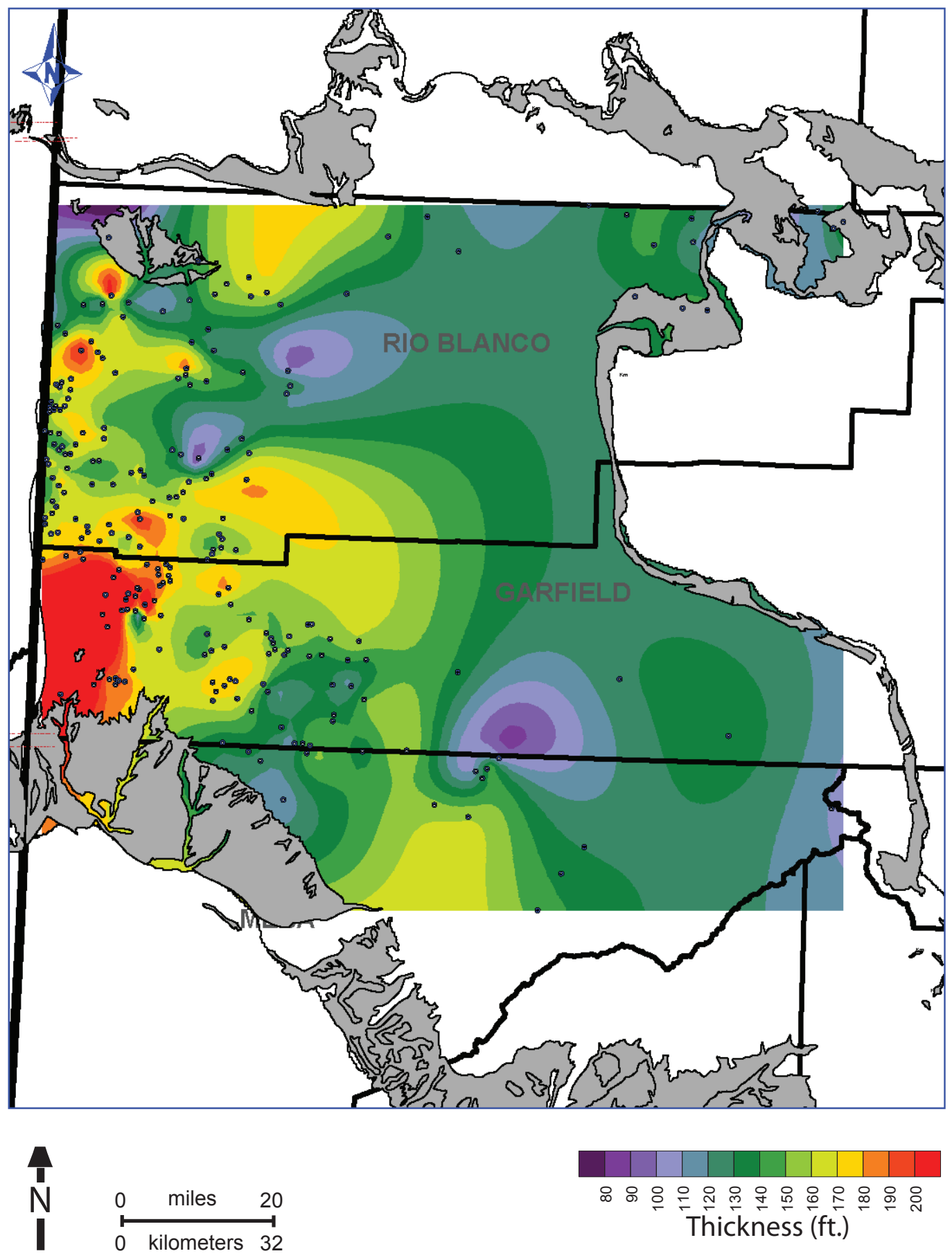

Isopach map of lithostratigraphic unit Niobrara 5. 

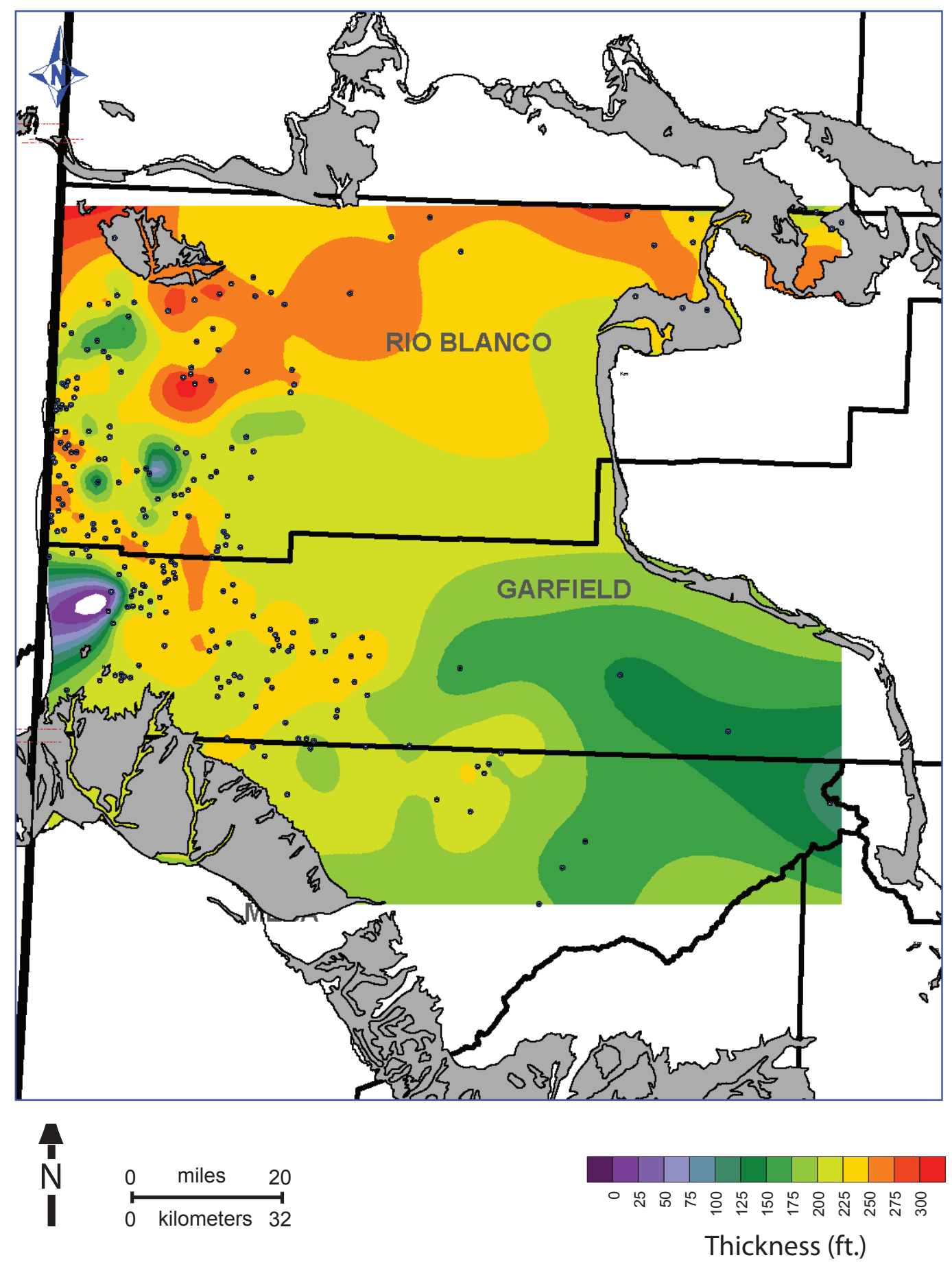

Isopach map of lithostratigraphic unit Niobrara 6 . 

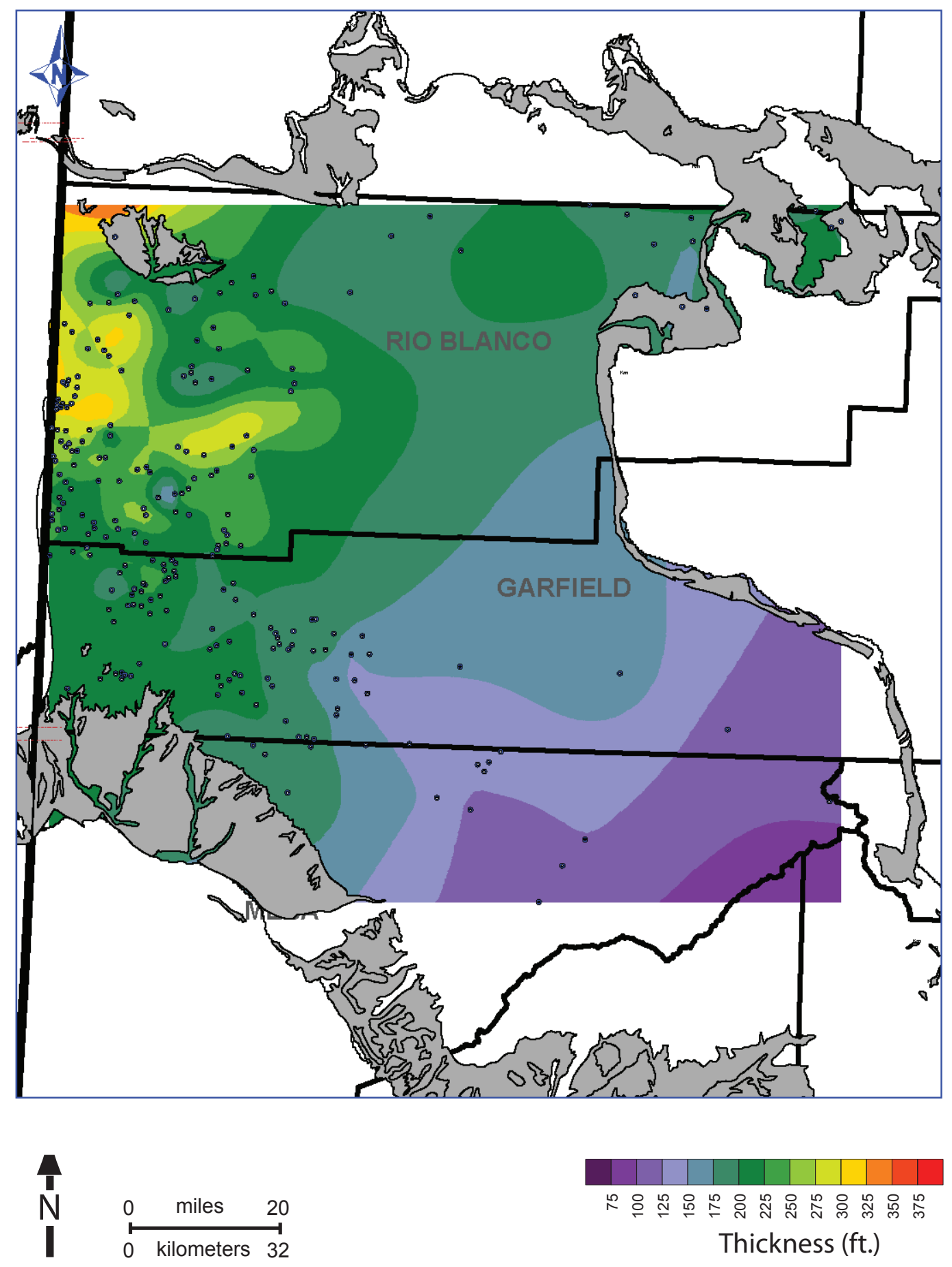

Isopach map of lithostratigraphic unit Niobrara 7. 


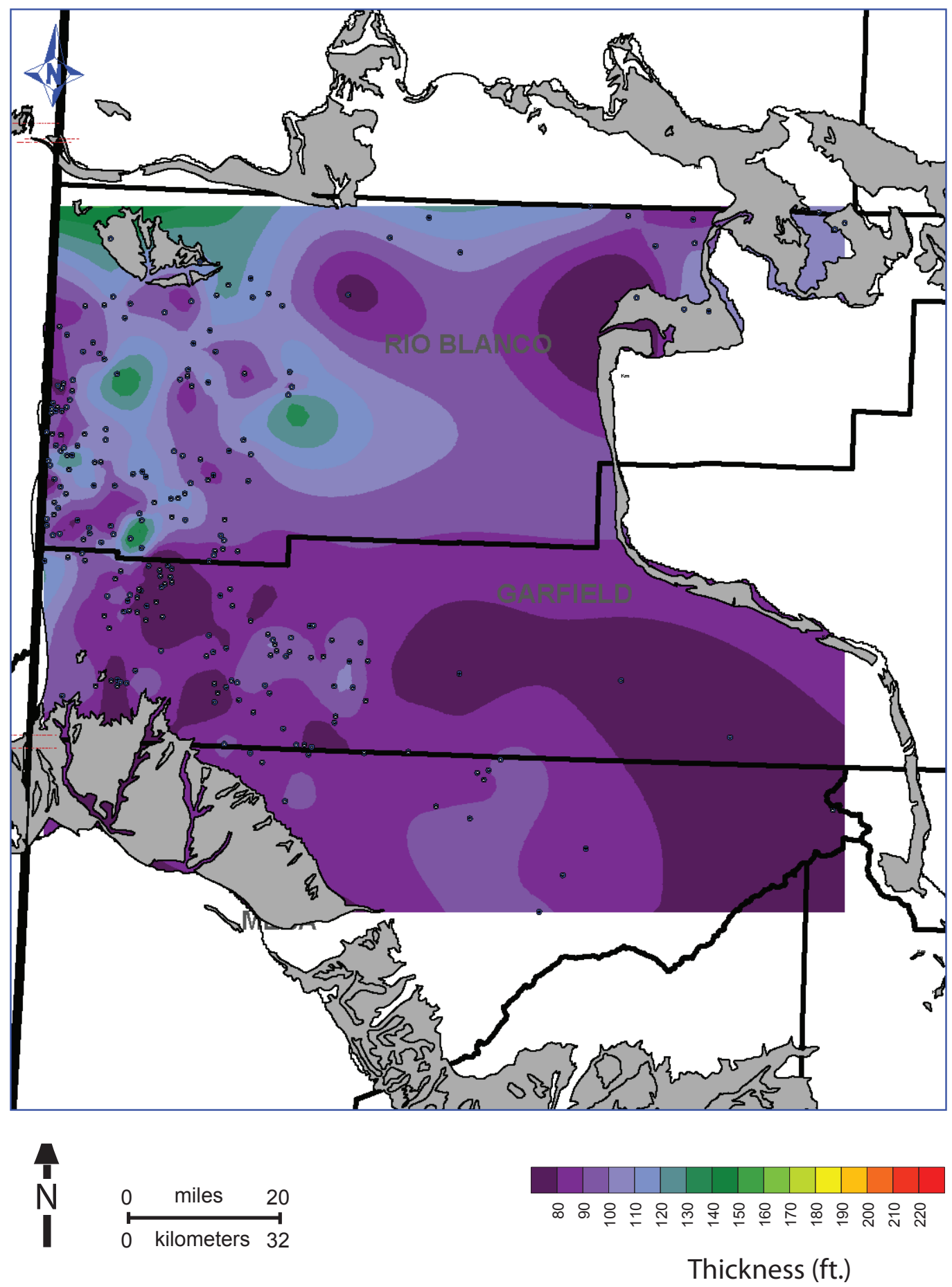

Isopach map of lithostratigraphic unit Niobrara 8. 


\section{Appendix D}

\section{Geochemical Profiles}

Appendix D contains geochemical profiles of chemostratigraphical index elements (Ca, Si, Si/Al, $\mathrm{Al}, \mathrm{Fe}, \mathrm{K} / \mathrm{Al}, \mathrm{Mo}, \mathrm{Cr}+\mathrm{V}$, Ti, and $\mathrm{Zr}$ ) for 8 wells. 


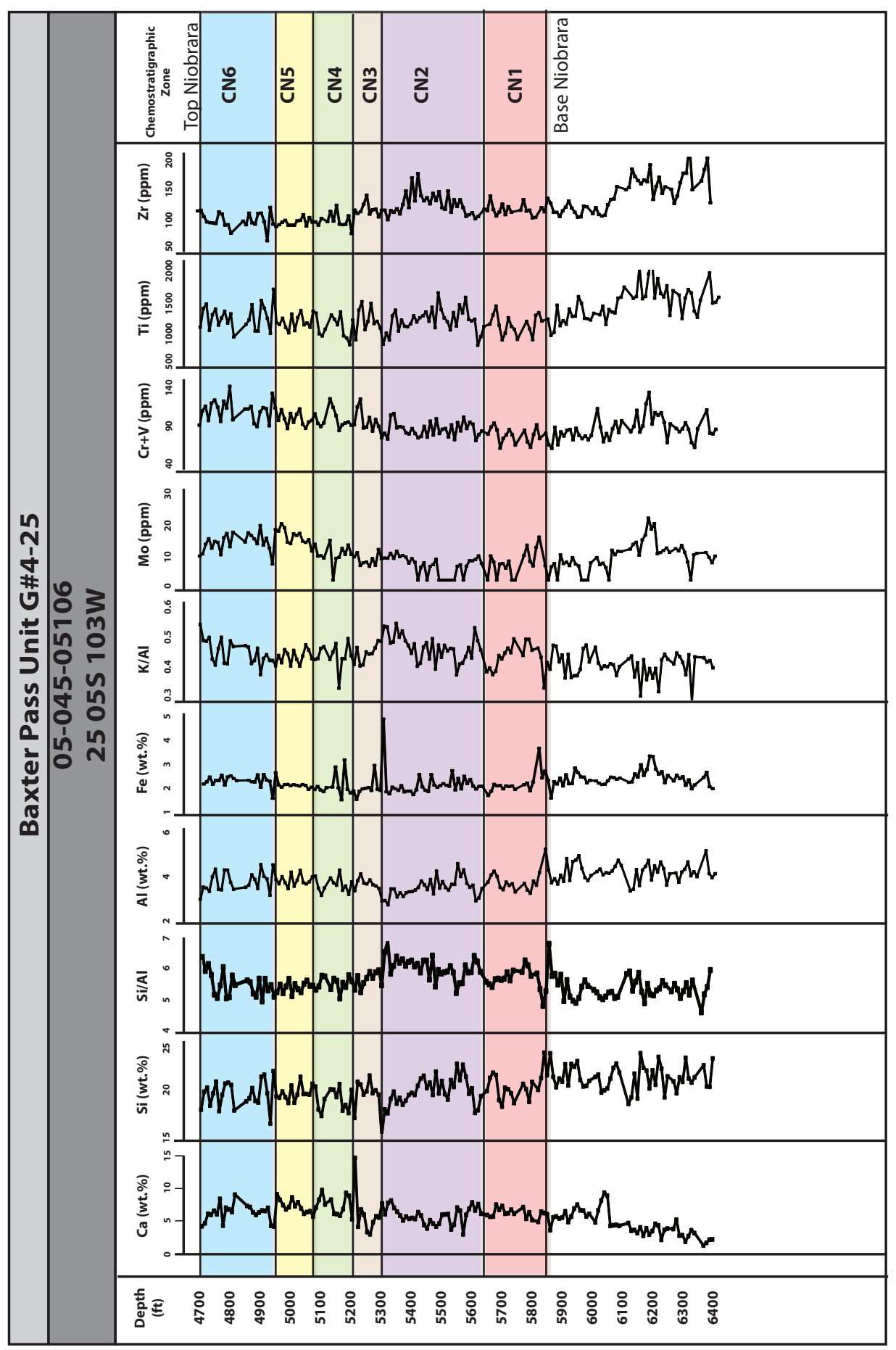




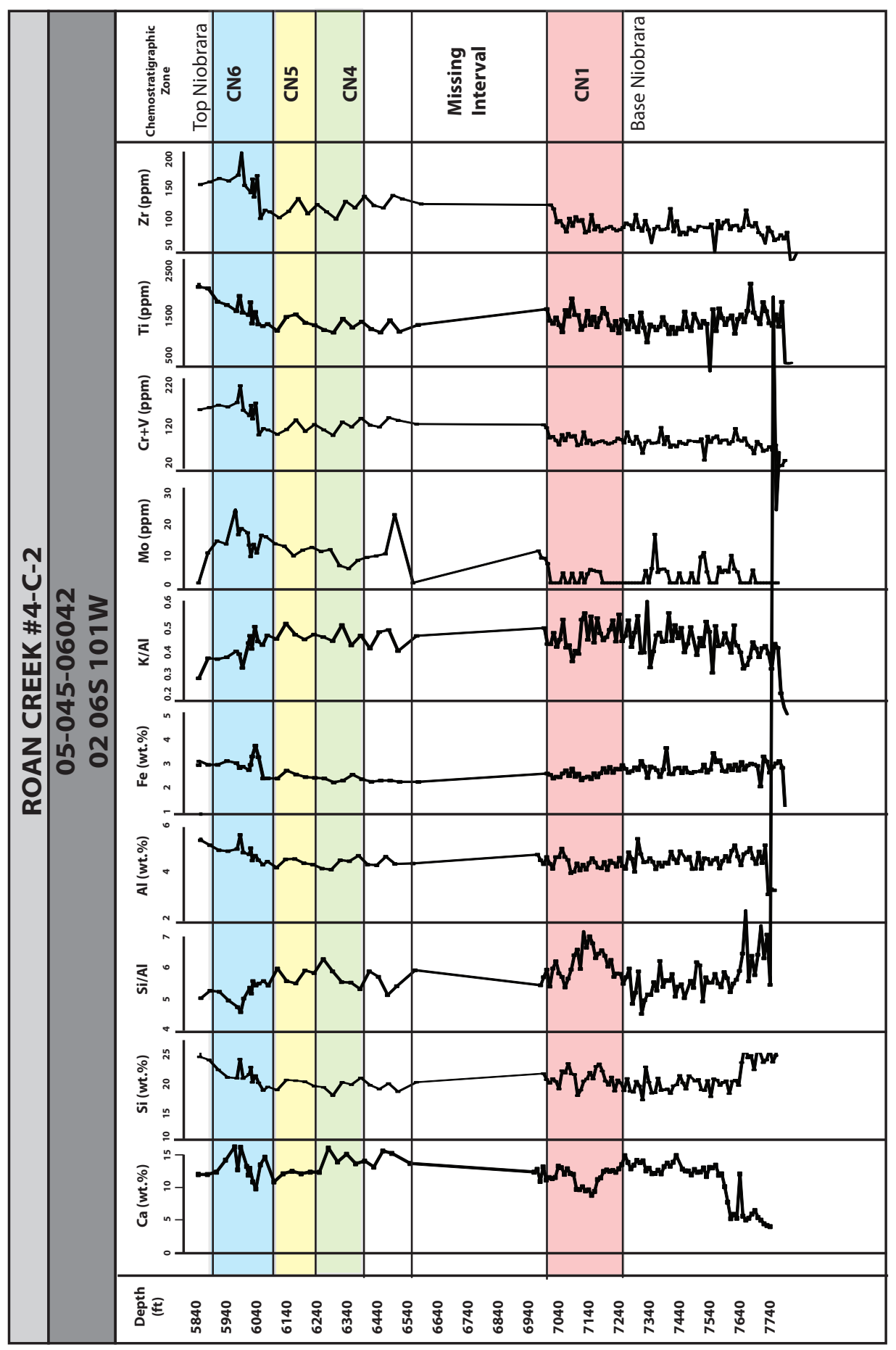




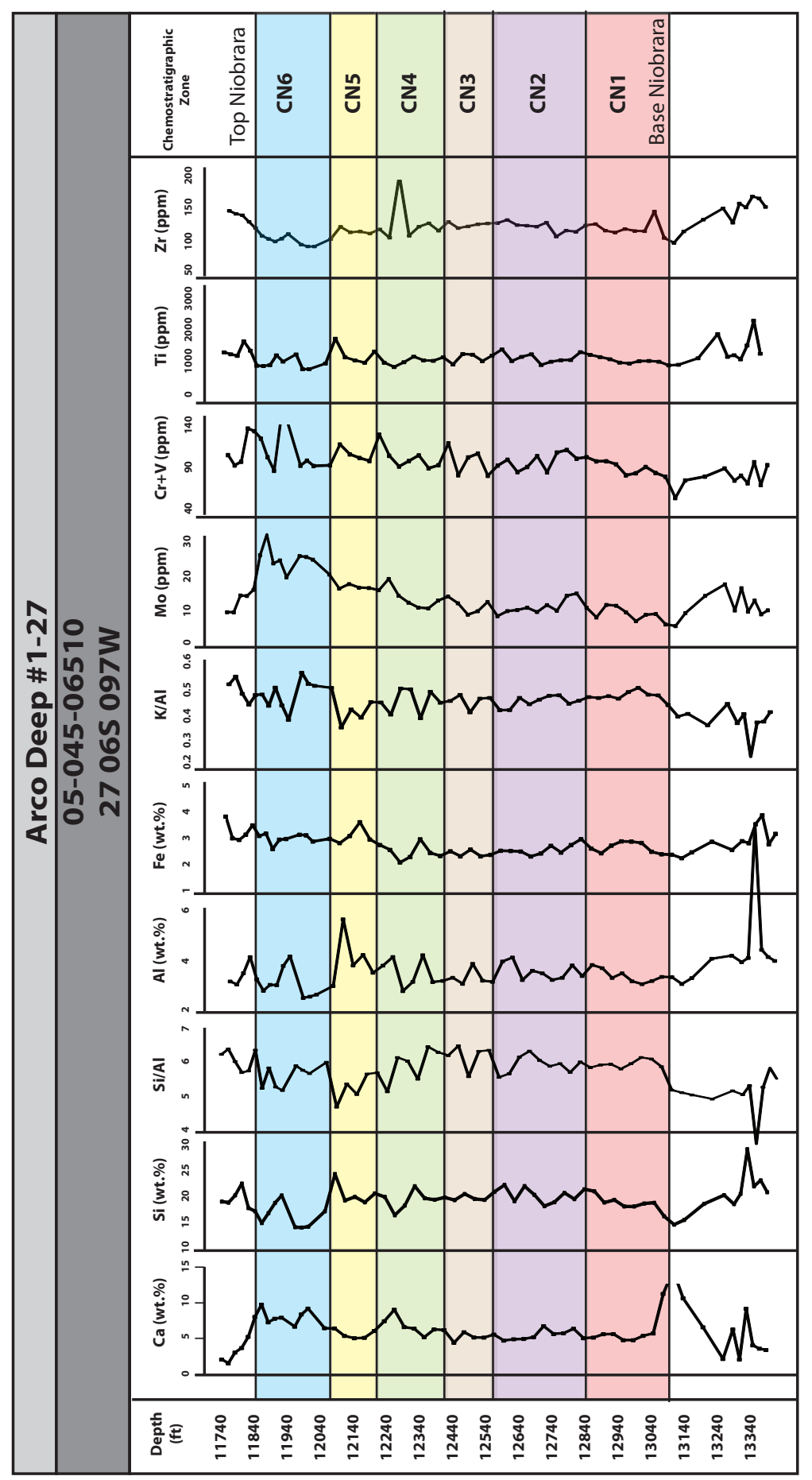




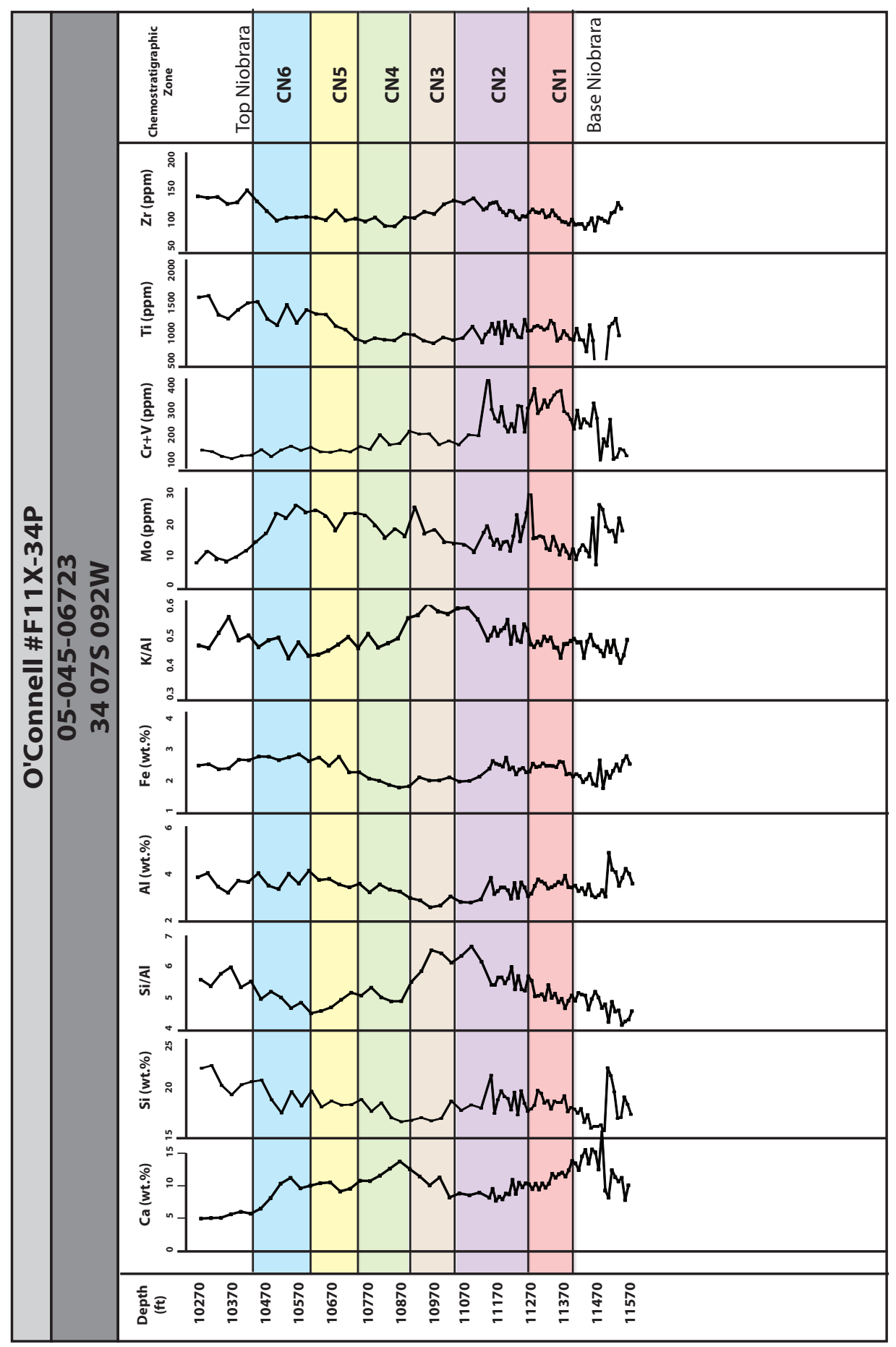




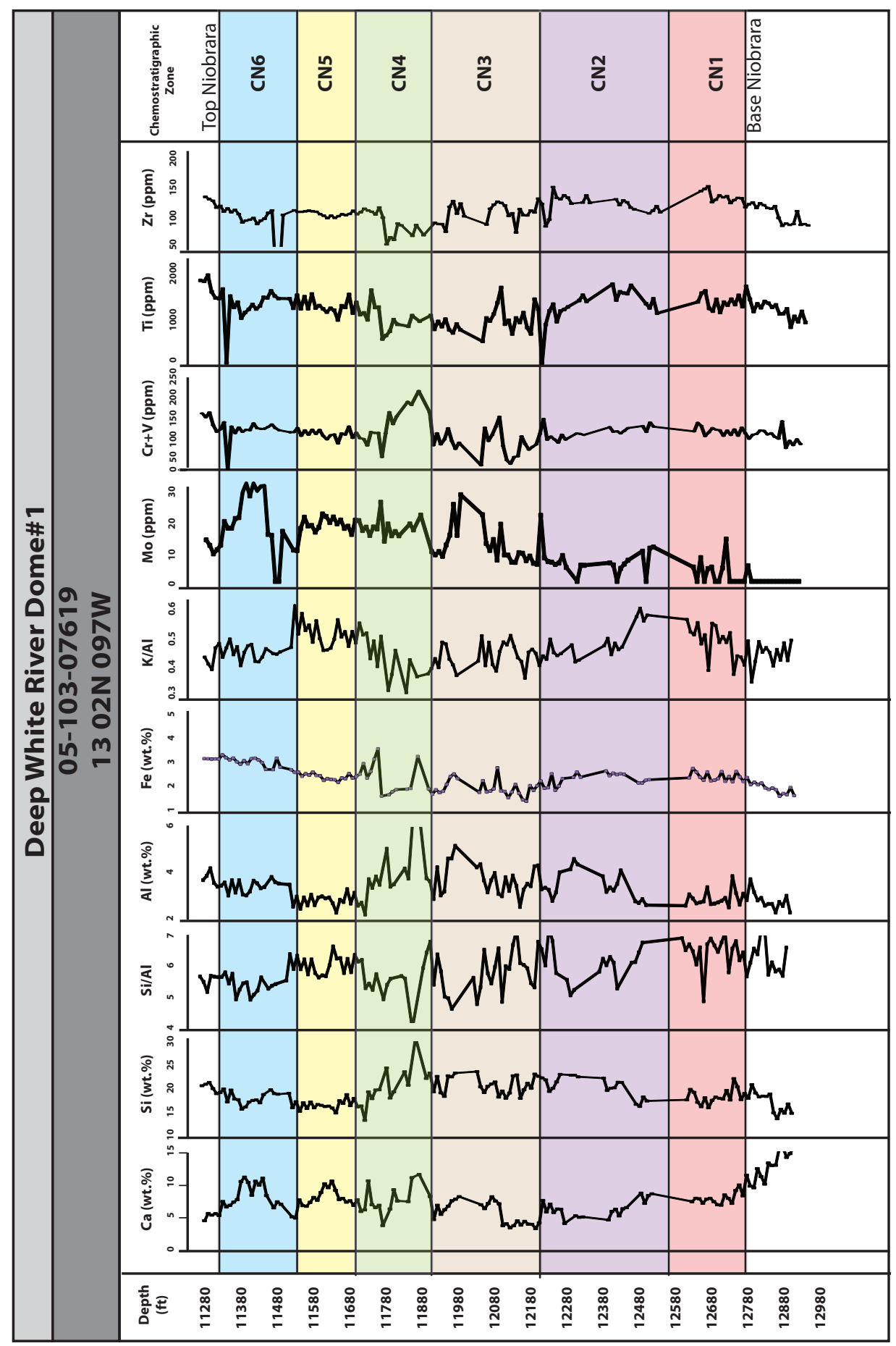


89

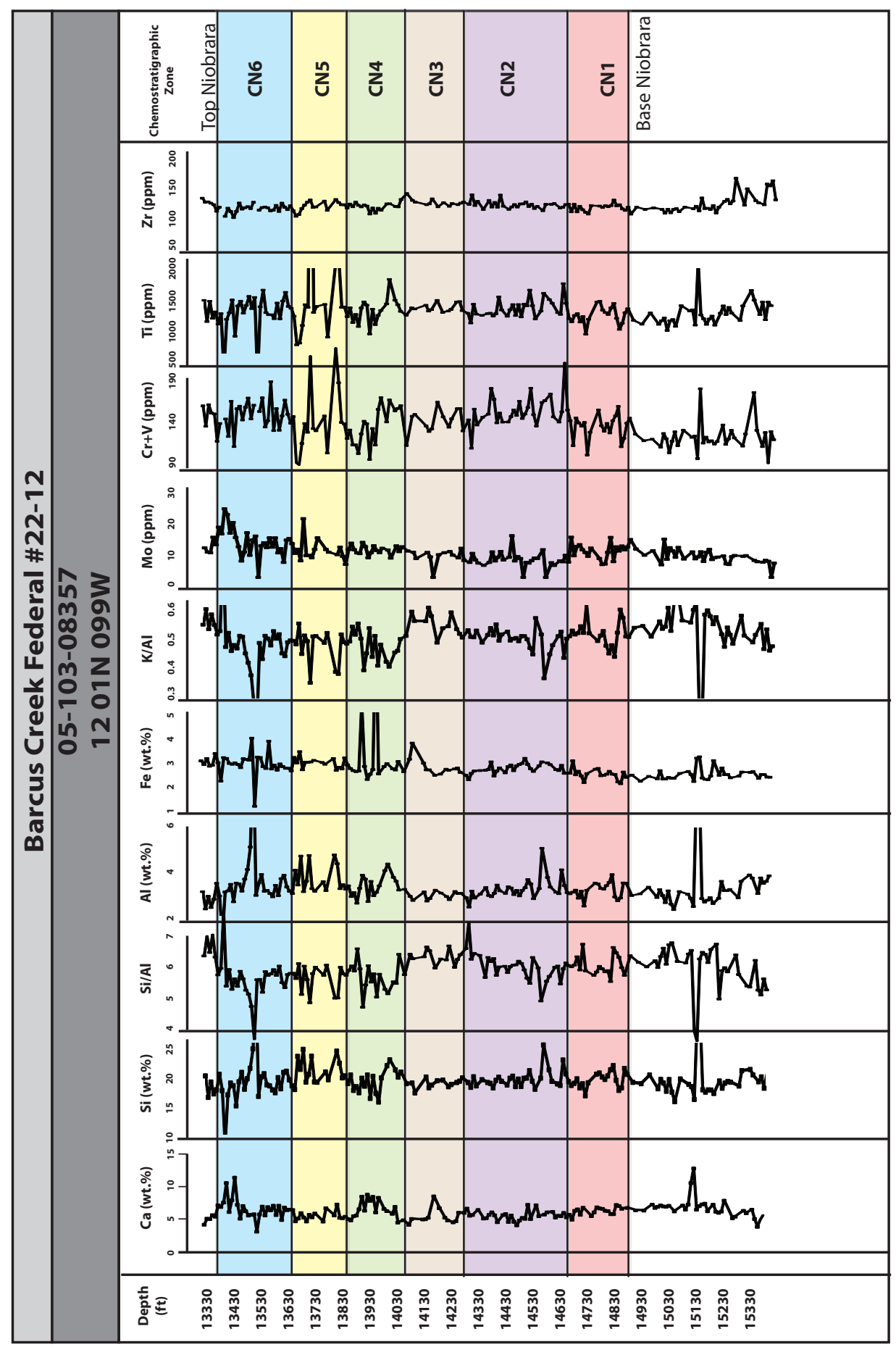




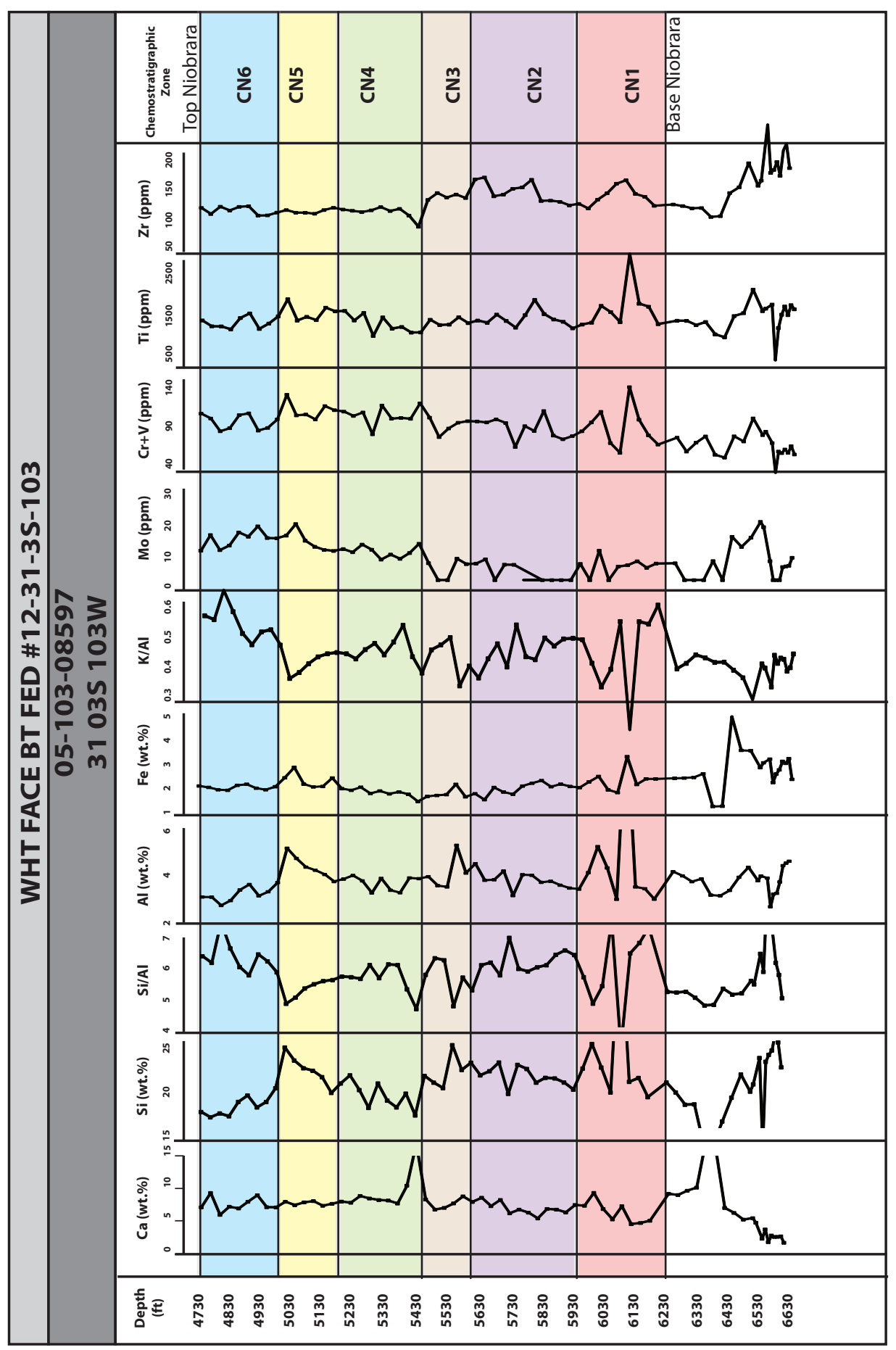




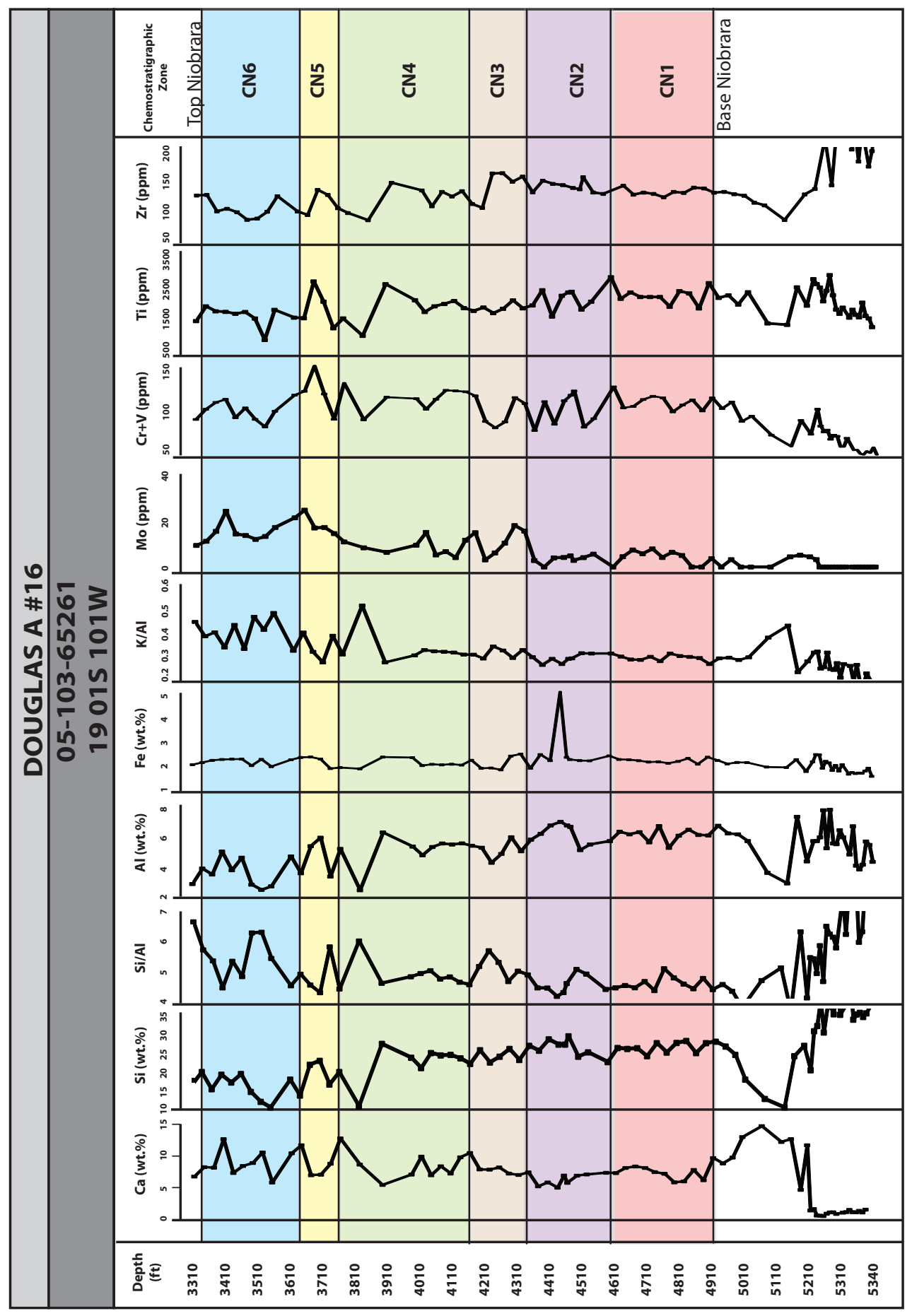


Appendix E

\section{Element and Element Ratio Maps}

Appendix E contains average element maps $(\mathrm{Cr}+\mathrm{V}, \mathrm{Si}, \mathrm{Ti}+\mathrm{K})$ and element ratio $(\mathrm{K} / \mathrm{Al})$ maps for the six chemostratigraphic zones of the Niobrara Member. 

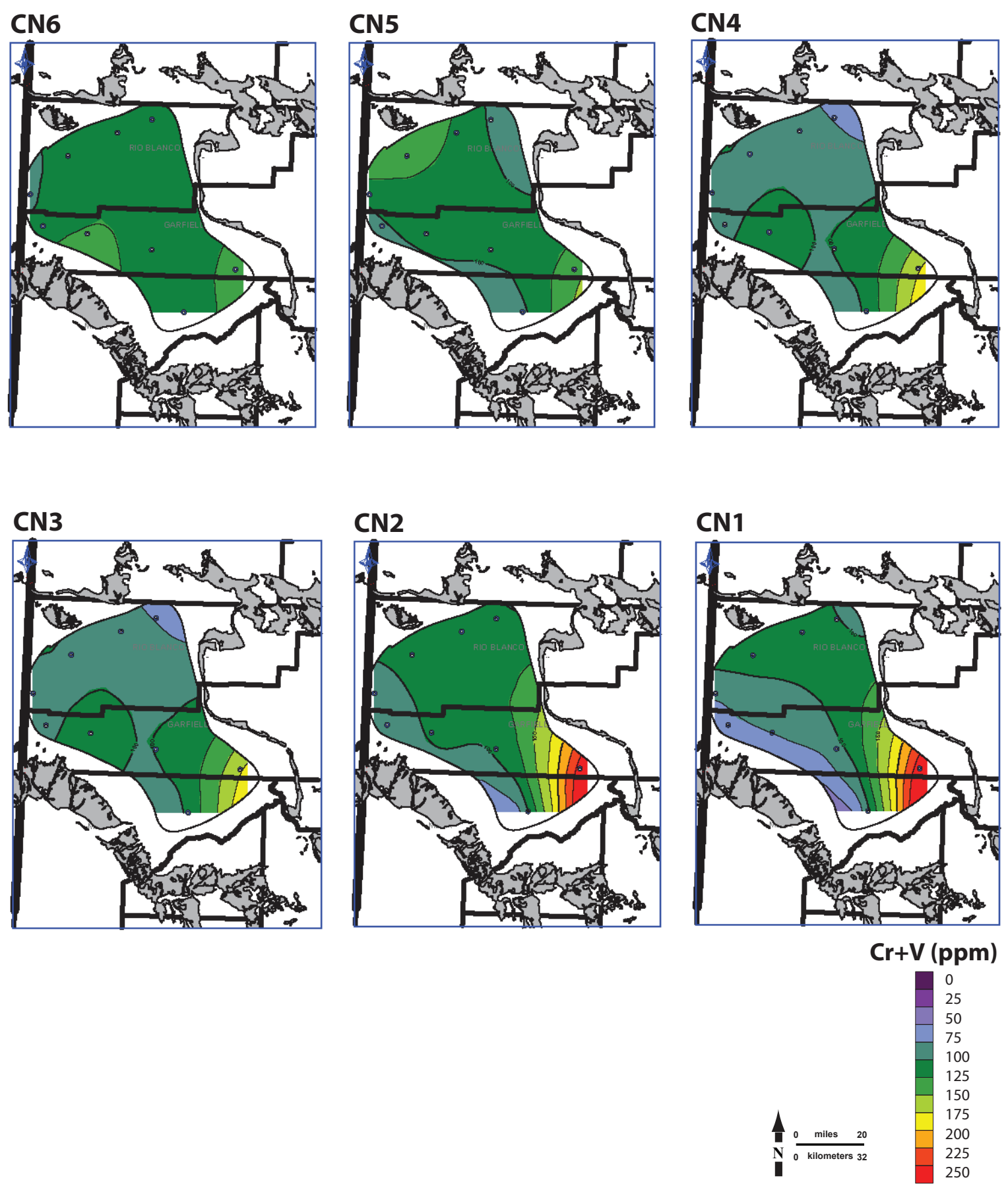

Average $\mathrm{Cr}+\mathrm{V}$ (ppm) maps for the six chemostratigraphic zones of the Niobrara Member. Overall, $\mathrm{Cr}+\mathrm{V}$ values increase to the east of the Piceance Basin. 

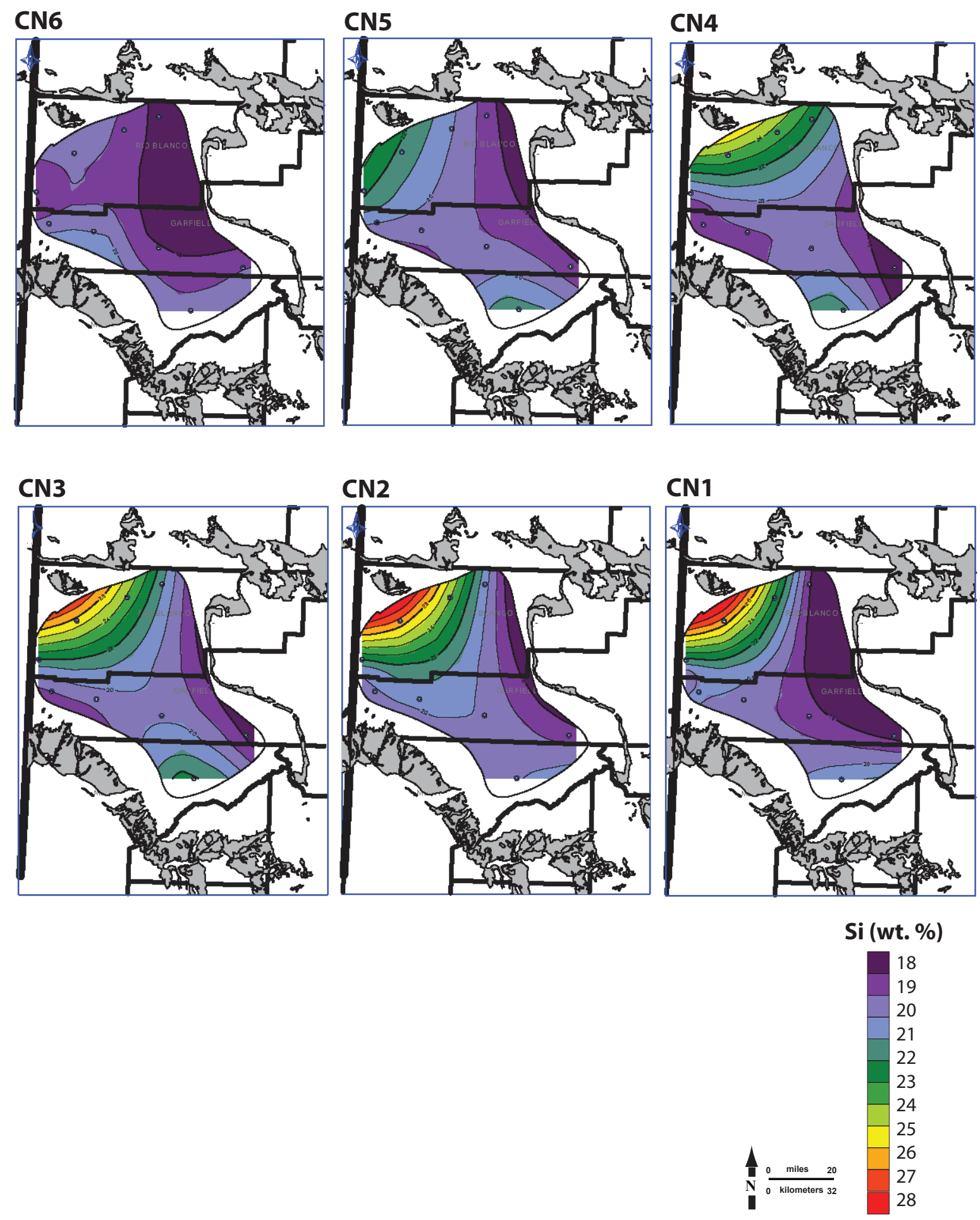

Average Si (wt.\%) maps for the six chemostratigraphic zones of the Niobrara Member. Overall, Si values increase to the northwest of the Piceance Basin. 

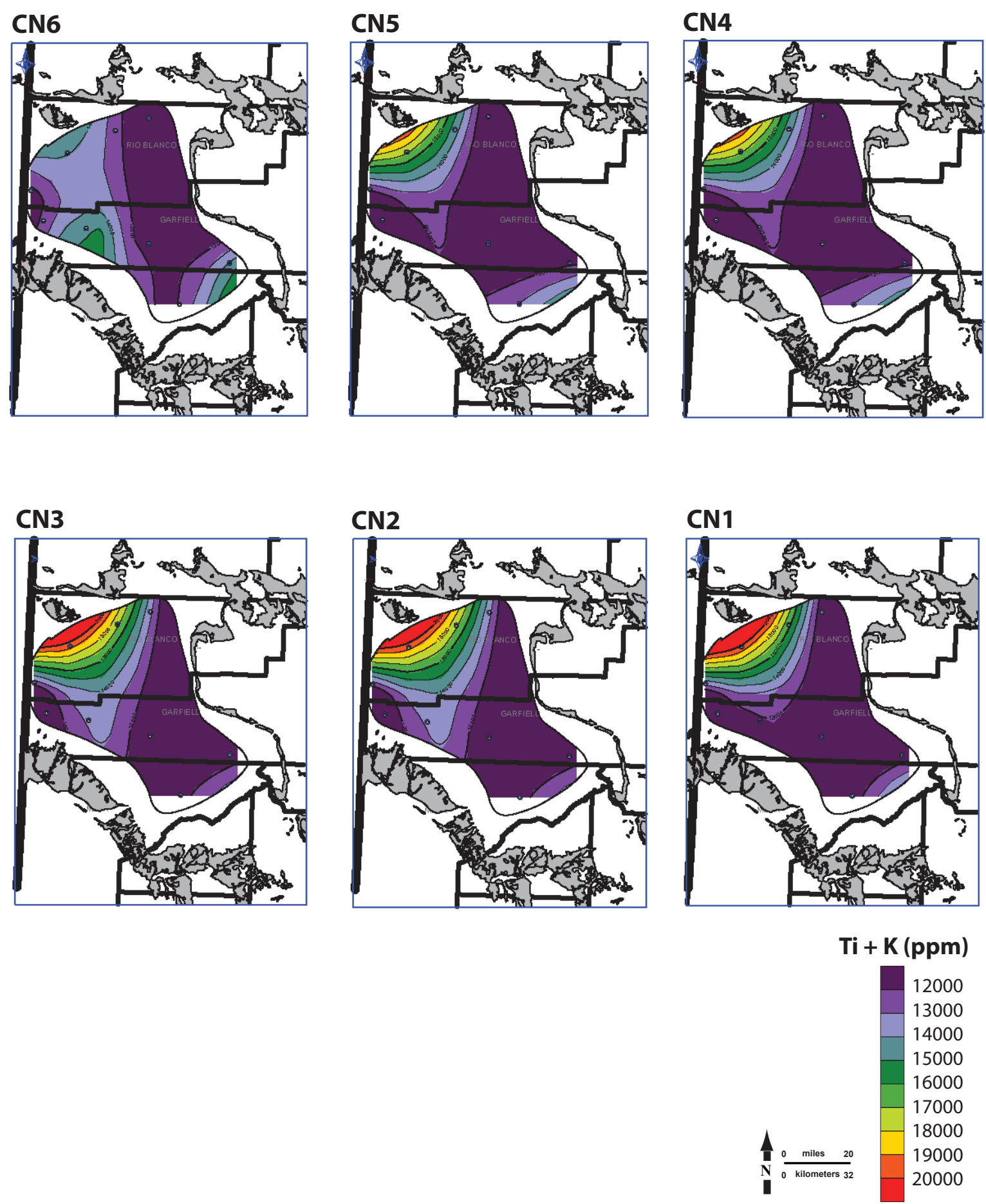

Average Ti+K (ppm) maps for the six chemostratigraphic zones of the Niobrara Member. Overall, $\mathrm{Ti}+\mathrm{Kl}$ values increase to the northwest of the Piceance Basin. 

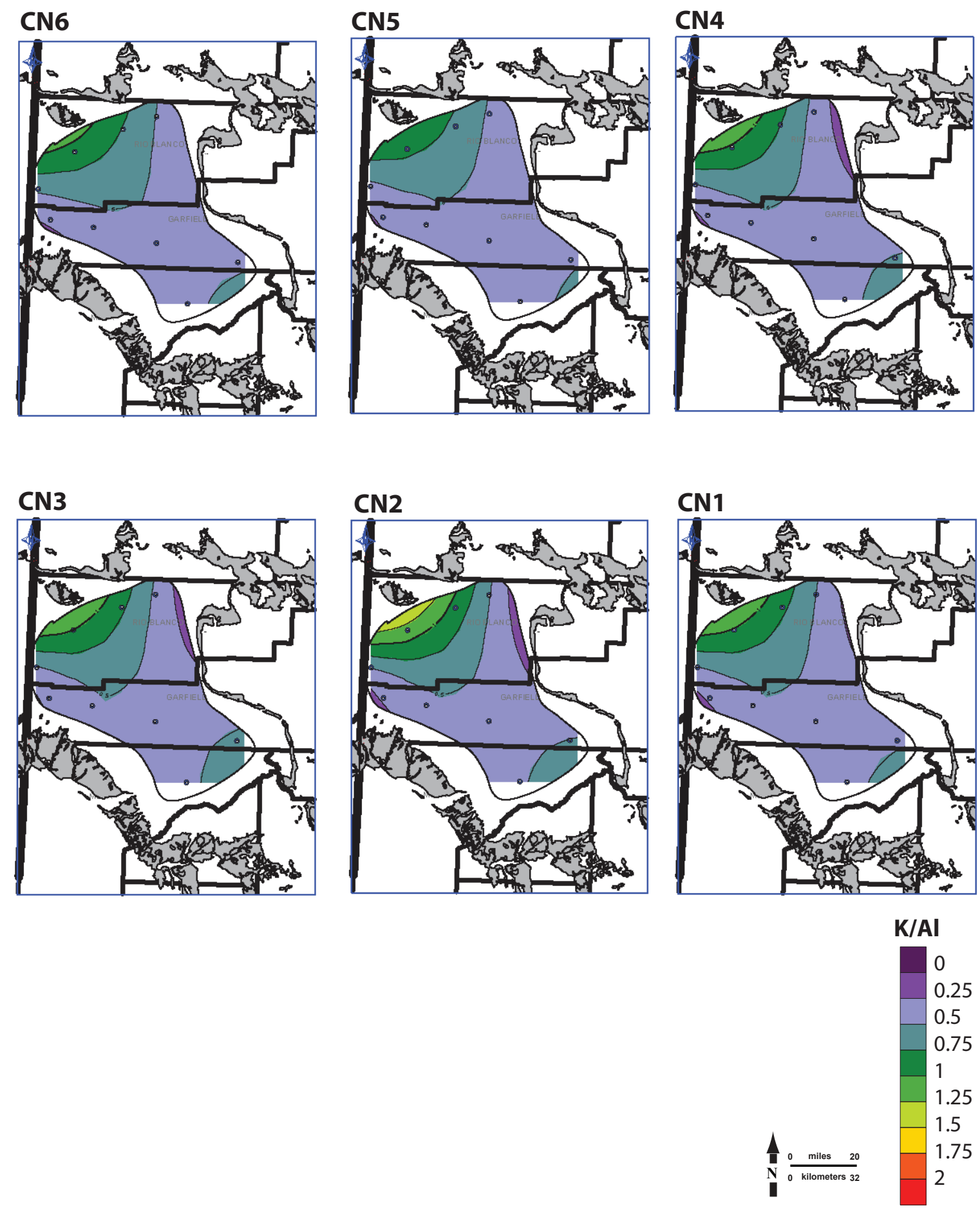

Average K/Al maps for the six chemostratigraphic zones of the Niobrara Member. Overall, K/Al values increase to the northwest of the Piceance Basin. 


\section{Appendix F}

\section{Element Cross-Plots}

Appendix F contains element cross plots (Fe vs. Al, Si vs. Zr, Ti vs. Al, and V vs. Al) constructed for all nine wells. 

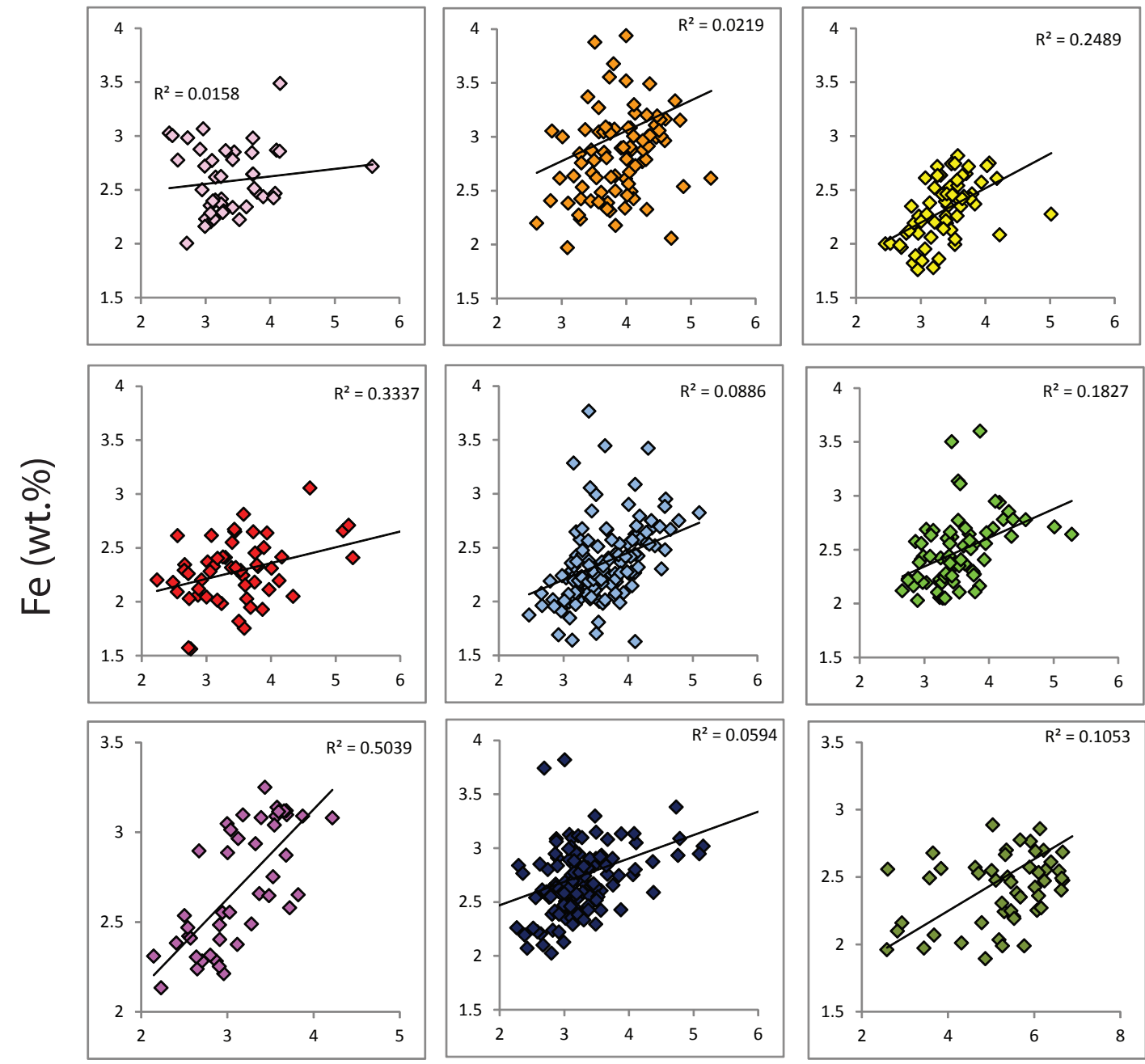

Al (wt.\%)

$\diamond$ Arco Deep 1-27

$\diamond$ Kathlyn Young \#1-15 $\diamond \mathrm{O}^{\prime}$ Connell \#F11X-34P

White Face Bt Fed 12-31-3S \#103

$\diamond$ Baxter Pass South

Roan Creek \#4-C-2

Deep White River

Dome \# 1

Barcus Creek

Federal \#22-12

Douglas A \#16 

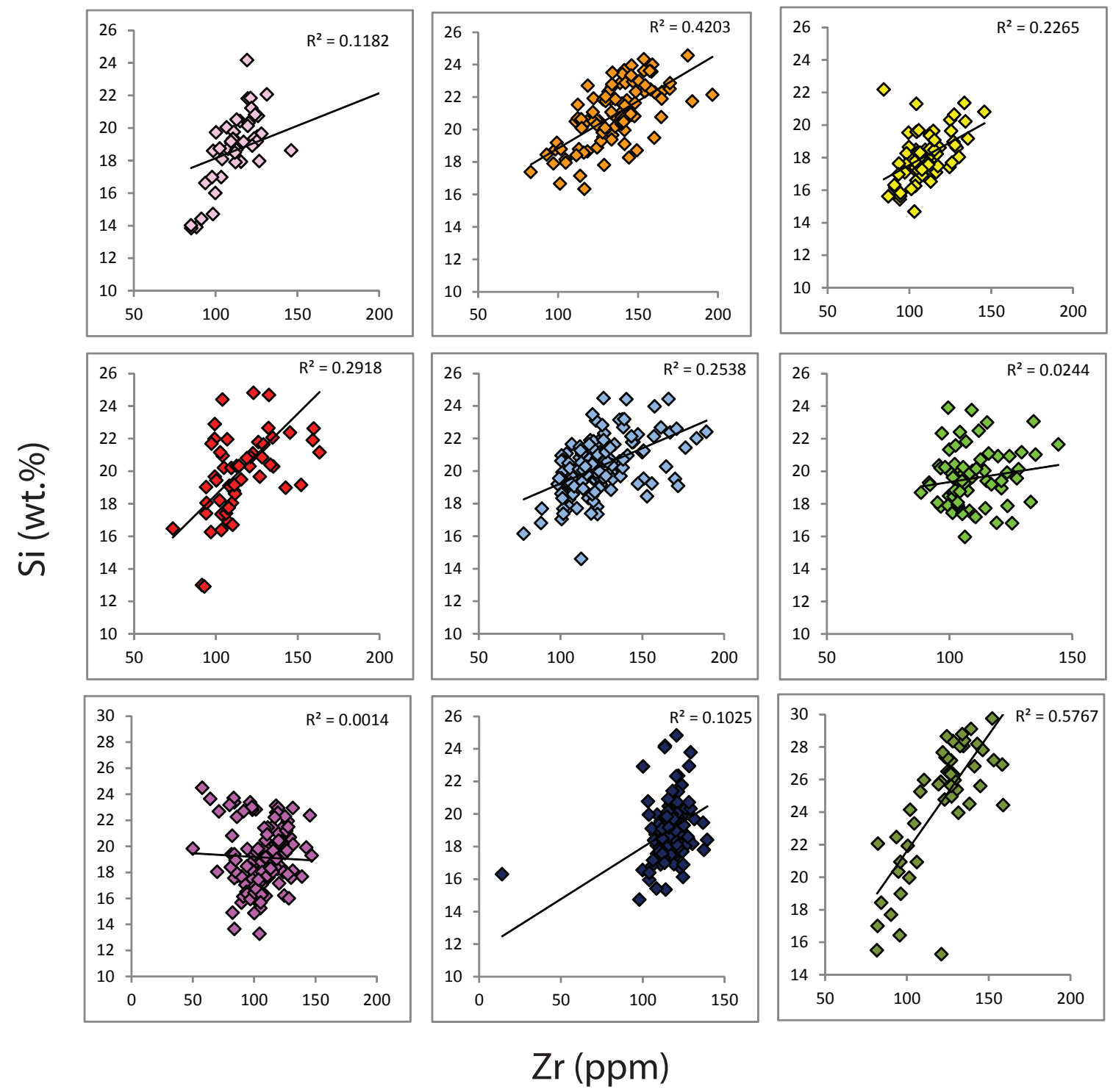

$\operatorname{Zr}(\mathrm{ppm})$

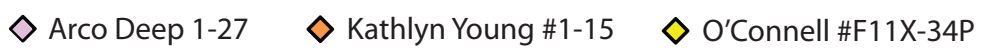

$\diamond$ White Face Bt Fed 12-31-3S \#103

$\checkmark$ Baxter Pass South

$\diamond$ Roan Creek \#4-C-2

Deep White River

Dome \#1 Unit-G \#4-25

$\diamond$ Douglas A \#16

Barcus Creek

Federal \#22-12 

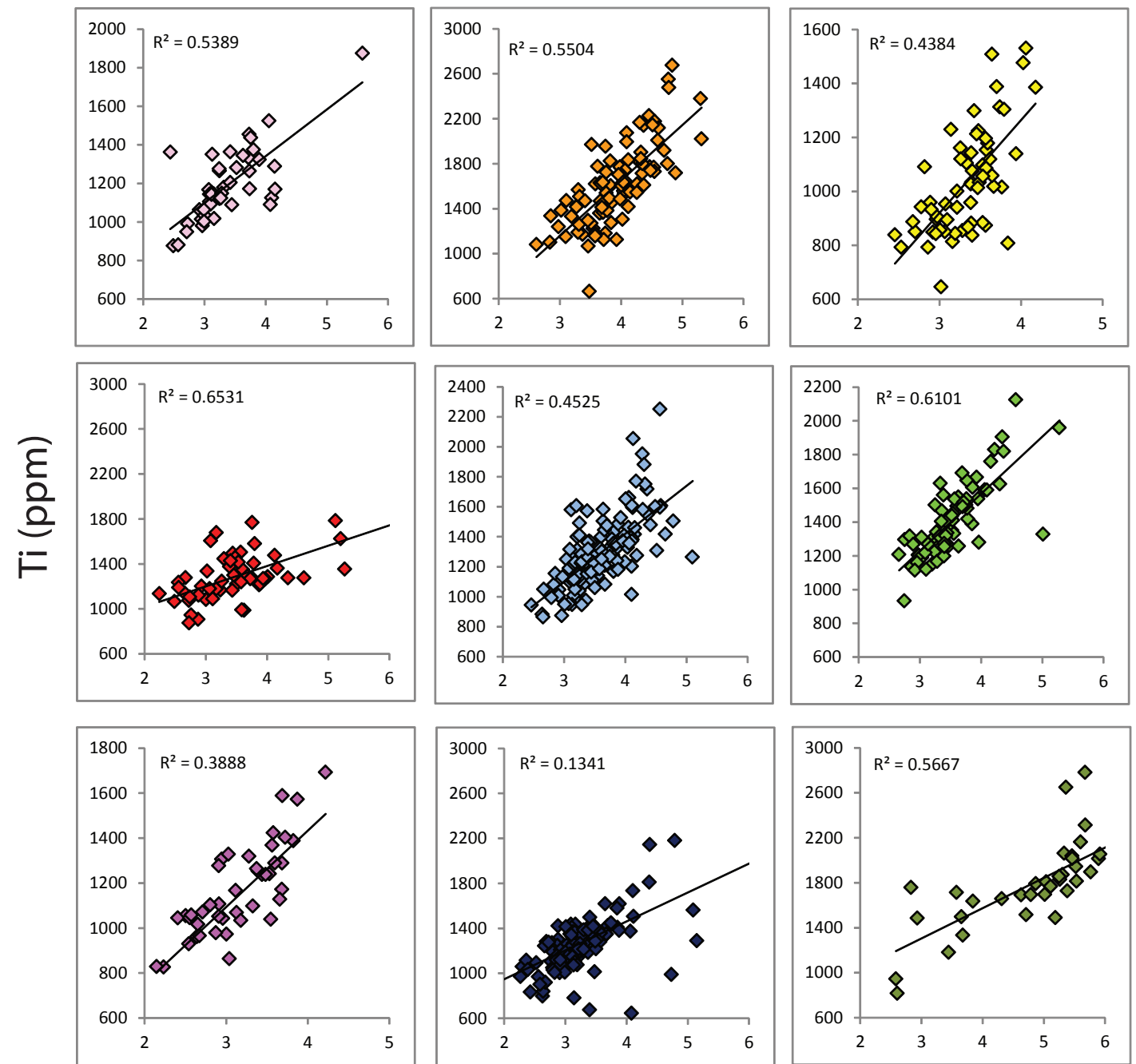

\section{Al (wt.\%)}

$\diamond$ Arco Deep 1-27 $\diamond$ Kathlyn Young \#1-15 $\diamond O^{\prime}$ Connell \#F11X-34P

$\diamond \begin{aligned} & \text { White Face Bt Fed } \\ & 12-31-3 S \# 103\end{aligned} \quad \begin{aligned} & \text { Baxter Pass South } \\ & \text { Unit-G \#4-25 }\end{aligned} \diamond$ Roan Creek \#4-C-2

$\diamond \begin{aligned} & \text { Deep White River } \\ & \text { Dome \#1 }\end{aligned} \begin{aligned} & \text { Barcus Creek } \\ & \text { Federal \#22-12 }\end{aligned}$ Douglas A \#16 


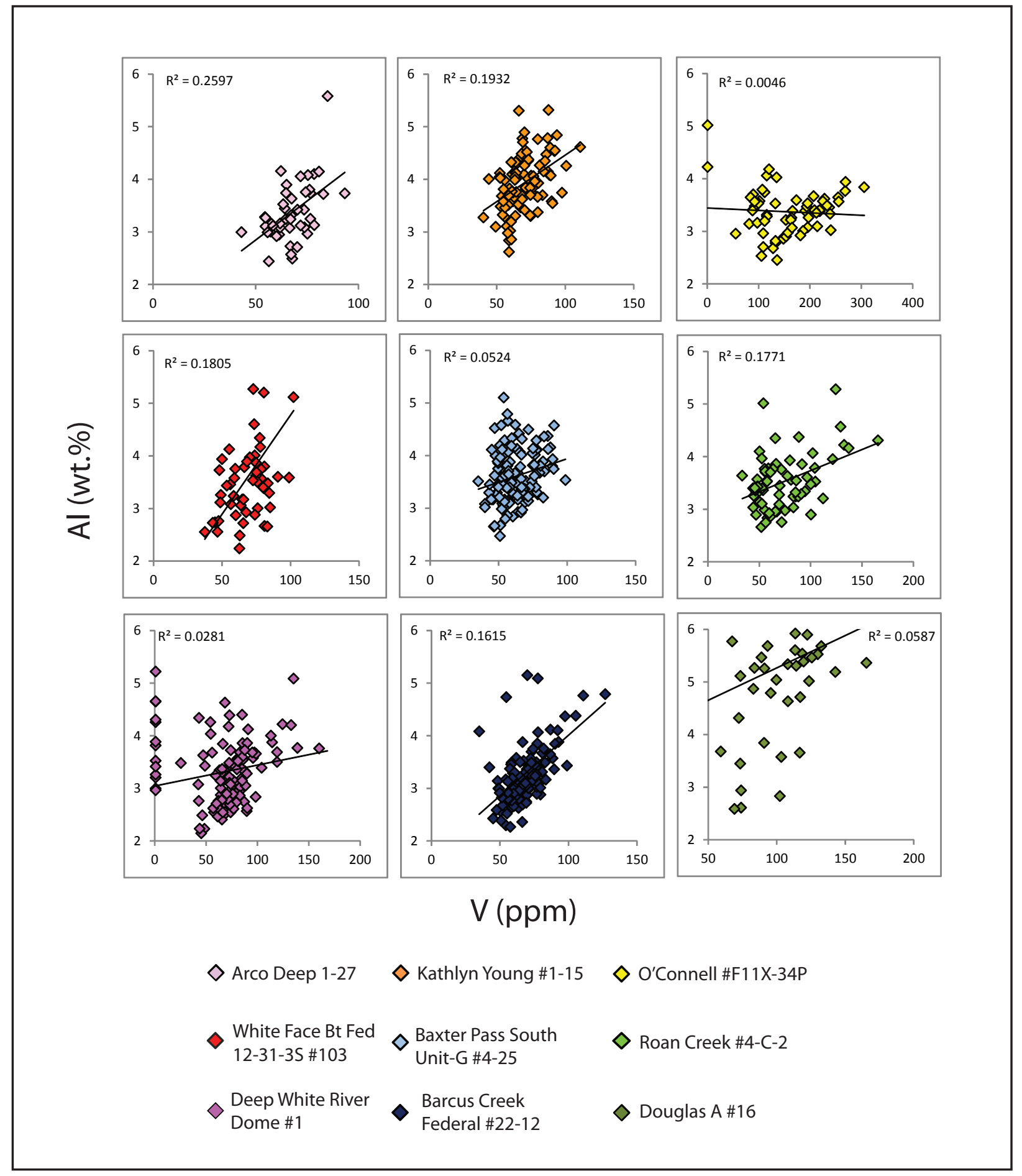


Appendix G

TOC Statistics 


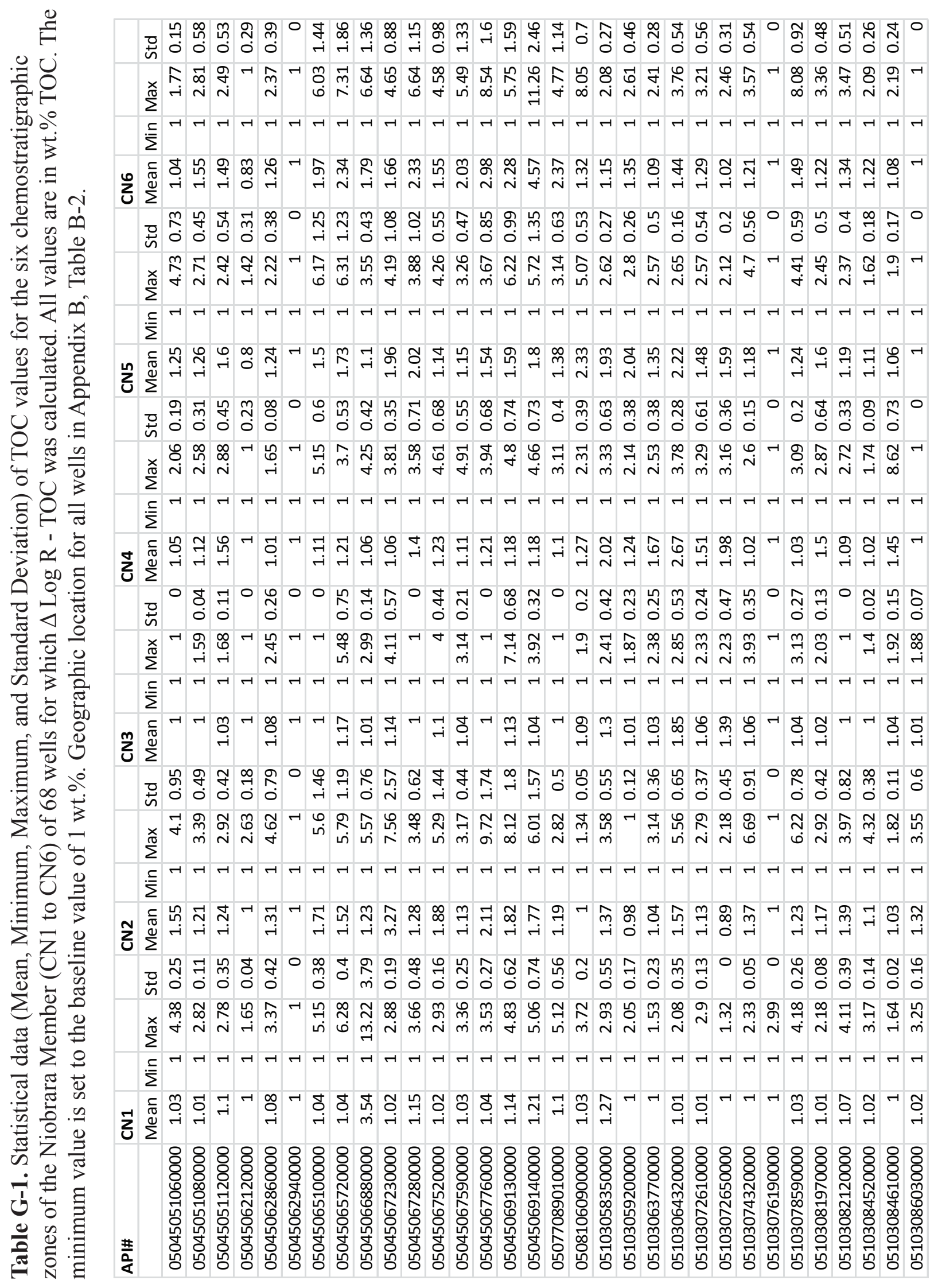


욜

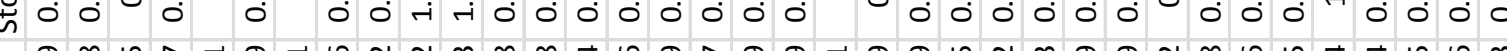

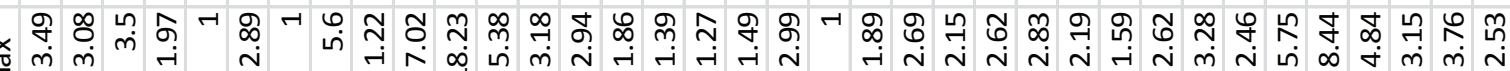

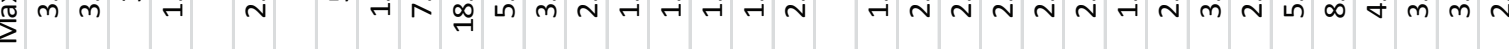
后

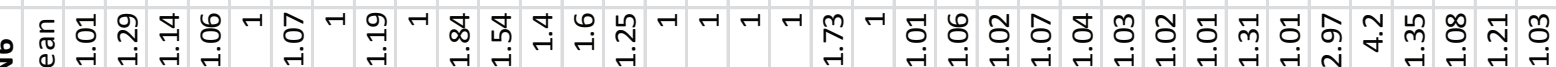
乙) $\sum^{0}$

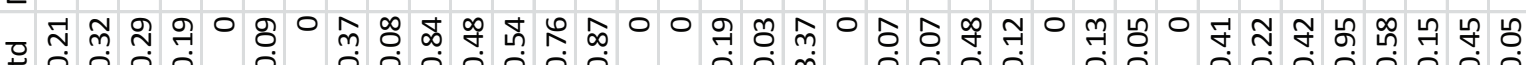

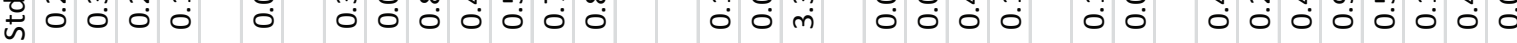

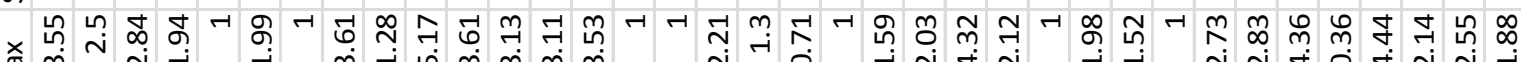

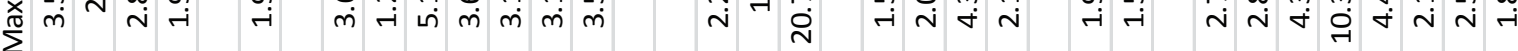
舀

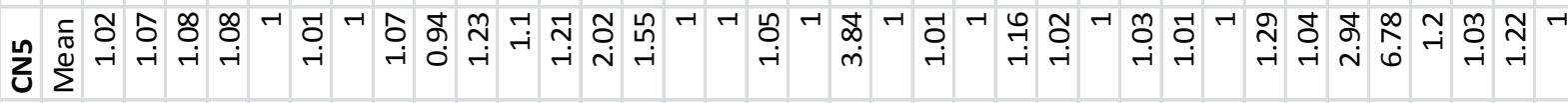

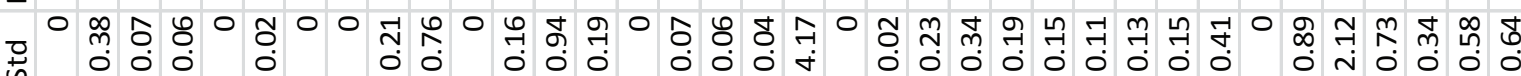

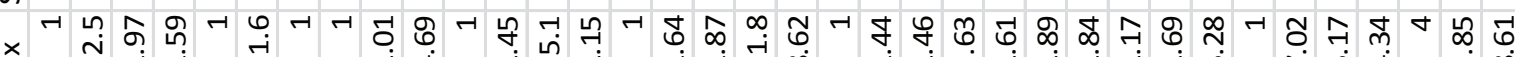

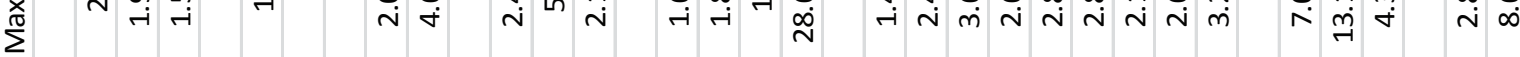
s 4 h $\dot{\Sigma}$

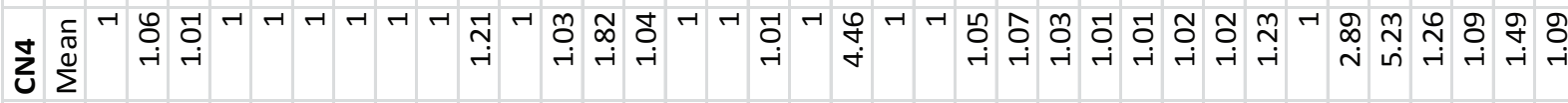
우 0 ○

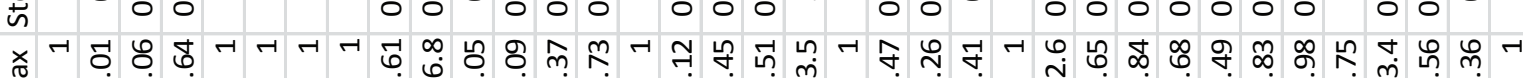

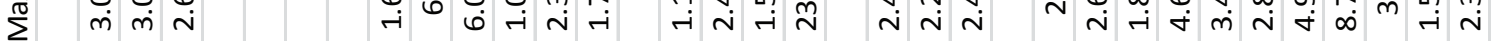

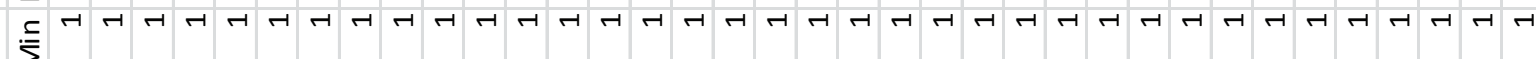

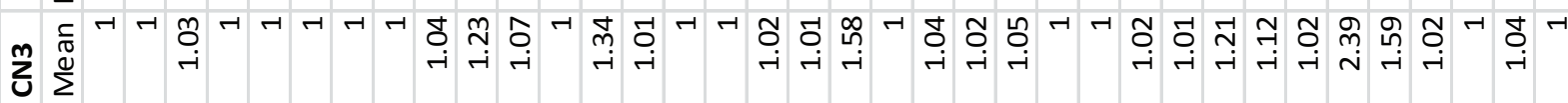

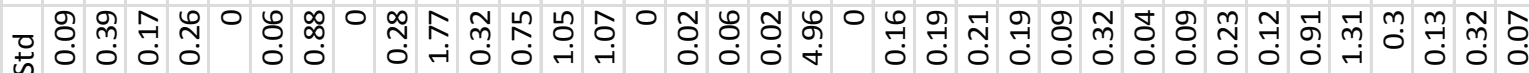

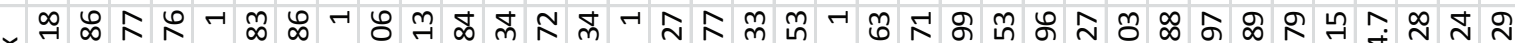
㸚

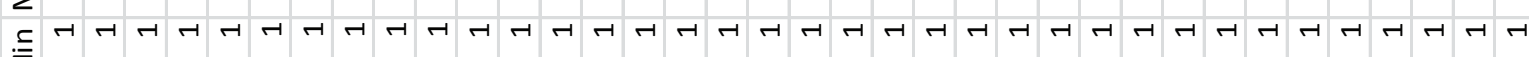
$\dot{\Sigma}$

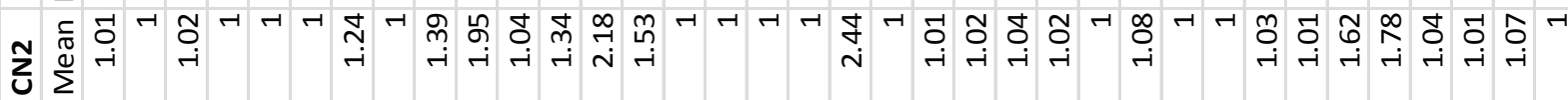

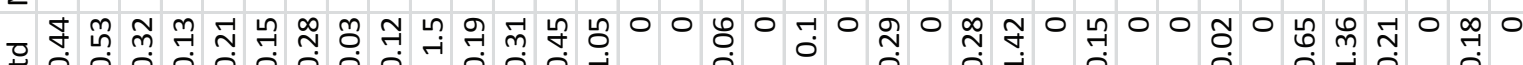

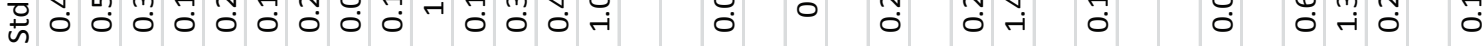

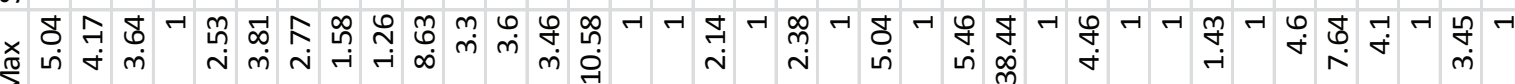
2 ह $\bar{\Sigma}$

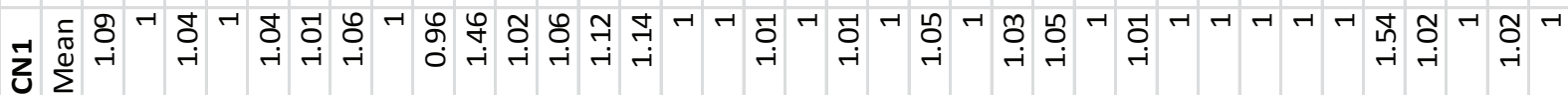

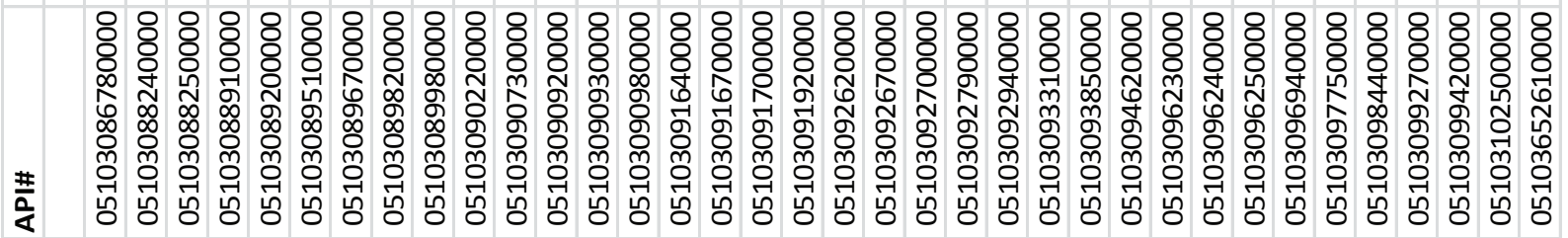

